\title{
O debate bioético e jurídico sobre as diretivas antecipadas da vontade
}

\author{
Matheus Massaro Mabtum \\ Patrícia Borba Marchetto
}

MABTUM, MM., and MARCHETTO, PB. O debate bioético e jurídico sobre as diretivas antecipadas de vontade [online]. São Paulo: Editora UNESP; São Paulo: Cultura Acadêmica, 2015,

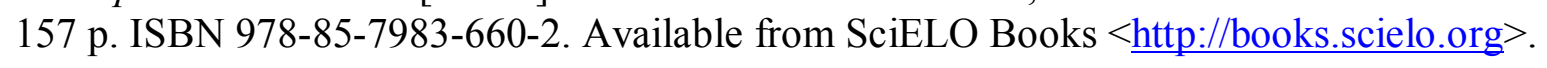

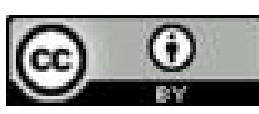

All the contents of this work, except where otherwise noted, is licensed under a Creative Commons Attribution 4.0 International license.

Todo o conteúdo deste trabalho, exceto quando houver ressalva, é publicado sob a licença Creative Commons Atribição $\underline{4.0}$.

Todo el contenido de esta obra, excepto donde se indique lo contrario, está bajo licencia de la licencia Creative Commons $\underline{\text { Reconocimento } 4.0 .}$. 


\section{- DEBATE BIOÉtTICO E JURÍDICO SOBRE AS DIRETIVAS ANTECIPADAS DA VONTADE}

MATHEUS MASSARO MABTUM PATRÍCIA BORBA MARCHETTO 


\section{O DEBATE BIOÉTICO E JURÍDICO SOBRE AS DIRETIVAS ANTECIPADAS DA VONTADE}


CONSELHO EDITORIAL ACADÊMICO

Responsável pela publicação desta obra

Prof. Dr. Paulo César Corrêa Borges

Profa. Dra. Elisabete Maniglia

Profa. Dra. Kelly Cristina Canela

Prof. Dr. Carlos Eduardo de Abreu Boucault

Prof. Dr. José Duarte Neto

Prof. Dr. Antonio Alberto Machado

Profa. Dra. Yvete Flávio da Costa

Profa. Dra. Jete Jane Fiorati 


\title{
MATHEUS MASSARO MABTUM PATRÍCIA BORBA MARCHETTO
}

\author{
O DEBATE \\ BIOÉTICO E JURÍDICO \\ SOBRE AS DIRETIVAS \\ ANTECIPADAS DA \\ VONTADE
}


(C) 2015 Editora Unesp

\section{Cultura Acadêmica}

Praça da Sé, 108

01001-900 - São Paulo - SP

Tel.: (0xx11) 3242-7171

Fax: (0xx11) 3242-7172

www.culturaacademica.com.br

www.livrariaunesp.com.br

feu@editora.unesp.br

CIP - Brasil. Catalogação na publicação

Sindicato Nacional dos Editores de Livros, RJ

M111d

Mabtum, Matheus Massaro

O debate bioético e jurídico sobre as diretivas antecipadas de vontade [recurso eletrônico] / Matheus Massaro Mabtum, Patrícia Borba Marchetto. - 1.ed. - São Paulo: Cultura Acadêmica, 2015.

Recurso digital

Formato: ePub

Requisitos do sistema: Adobe Digital Editions

Modo de acesso: World Wide Web

ISBN 978-85-7983-660-2 (recurso eletrônico)

1. Responsabilidade civil. 2. Direito e biologia. 3. Bioética. 4. Livros eletrônicos. I. Marchetto, Patrícia Borba. II. Título.

CDU: 340.12

Este livro é publicado pelo Programa de Publicações Digitais da Pró-Reitoria de Pós-Graduação da Universidade Estadual Paulista "Júlio de Mesquita Filho" (Unesp)

Editora afiliada:

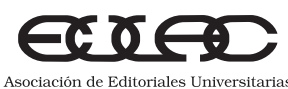

Asociación de Editoriales Universitarias de América Latina y el Caribe

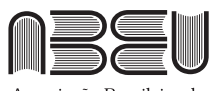

Associação Brasileira de Editoras Universitárias 
Dedico este trabalho aos meus pais, Mércia Aparecida Massaro e Elias Antonio Mabtum, por terem dedicado suas vidas e dado a mim todo o amor, carinho e atenção que um filho poderia sonhar, por seu companheirismo e pelo apoio necessário em toda a minha vida, sem jamais medirem esforços para que eu chegasse até aqui. Dedico também à minha namorada Juliana Paula Sartore Donini, que, mesmo nos momentos mais difíceis, acreditou em mim, incentivou-me e estimulou-me a prosseguir. Dedico, por fim, à minha madrinha, Aparecida Mabtum, e aos meus avós (in memoriam), pelo afeto e pela compreensão. 
Egoísmo não é viver à nossa maneira, mas desejar que os outros vivam como nós queremos.

(Oscar Wilde) 


\section{SUMÁRIO}

Introdução 11

1 Concepções teóricas sobre bioética, biodireito e dignidade humana 17

2 Concepções teóricas sobre a terminalidade da vida 53

3 Reflexões sobre o consentimento livre e esclarecido 73

4 Diretivas antecipadas de vontade como dissentimento livre e esclarecido e a necessidade de aconselhamento médico e jurídico 89

Considerações finais 133

Referências bibliográficas 139

Sobre os autores 157 


\section{INTRODUÇÃO}

A humanidade sempre se preocupou em buscar suas origens, mas não se contentou em saber apenas de si: procurou conhecer a verdade sobre tudo que a rodeava, indo além e tentando, com base nos seus conhecimentos, entender como as coisas funcionavam, visando alcançar melhor qualidade de vida e maior longevidade.

Movidas por esses mesmos ideais, as pesquisas biomédicas começaram a se desenvolver com rigor metodológico somente a partir do século XIX, justamente no período em que tiveram grande avanço. No século XVIII já havia produção científica, contudo amadorística e superficial. O século XX foi o século de ouro das pesquisas, em virtude da grande evolução biotecnológica que proporcionou o aprimoramento dos procedimentos científicos (Maluf; Garrafa, 2011).

A evolução biotecnológica que ocorreu principalmente nas últimas décadas do século XX e início do século XXI fez surgir questões que outrora seriam inimagináveis. Possibilitou grande avanço das biociências, mas originou muitas polêmicas, as quais requerem minuciosa análise ética e jurídica, porque a ciência só conseguirá atingir seus verdadeiros objetivos se a sua aplicação não violar os direitos fundamentais.

Alguns temas sempre foram inquietantes aos seres humanos, como a morte, a saúde, a segurança e o sigilo. A revolução biomé- 
dica possibilitou o prolongamento da vida, contudo nem sempre com qualidade. Muitas vezes, a dilatação da vida é sinônimo de sofrimento e dor.

Por esse motivo, deve-se analisar se a prática médico-hospitalar proporciona um alongamento da vida com qualidade e dignidade, ou apenas uma ampliação do processo de morte, aumentando a angústia do enfermo e de sua família e amigos.

As pessoas próximas, muitas vezes tomadas de um egoísmo inconsciente e não intencional, de início querem que seus entes queridos permaneçam ao seu lado o maior tempo possível, independentemente do custo, não apenas material, mas sobretudo humano. A cada dia cresce a preocupação com a relação médicopaciente, em especial no que diz respeito aos direitos do paciente. A atividade médica, ao longo do tempo, perdeu a aura de sacralidade que possuía na antiguidade. O médico deixou de ser visto como um sacerdote, que detinha em suas mãos, em razão de seu ofício, um poder metafísico de determinar quem seria ou não curado de uma enfermidade. Atualmente, o profissional da saúde é visto como qualquer outro trabalhador, sujeito a erros, acertos e críticas, e o paciente não é mais visto como uma figura inferiorizada, sujeita aos desejos e decisões exclusivas do médico.

Com a grande revolução da biotecnologia e da medicina nas últimas décadas, temas anteriormente inimagináveis emergem eivados de polêmicas, merecendo uma análise ética e jurídica, para que a ciência atinja suas finalidades sem, contudo, violar os direitos humanos fundamentais.

A biotecnologia evoluiu e permanece avançando em ritmo acelerado. Com ela evoluíram os procedimentos de análise e de combate a enfermidades. Surgiram novas técnicas e a superespecialização dos profissionais da medicina, especialidades preventivas, curativas e paliativas; desenvolveu-se a medicina estética e clínica; houve inestimável avanço dos equipamentos. Mas o que ainda determina o sucesso ou não do tratamento é o relacionamento interpessoal que se estabelece entre os dois principais envolvidos: médico e paciente. 
Essa relação deve ser embasada na confiança e no respeito mútuos. Não haverá sucesso em qualquer procedimento ou conduta se ela for rompida.

Os novos conhecimentos sempre são utilizados com o escopo de minorar o sofrimento humano, ou existem outros interesses na sua utilização?

Não raro, os novos conhecimentos científicos empregados no intuito de prolongar a vida do paciente terminal, ao invés de lhe darem mais qualidade de vida, acabam por violar o seu corpo e a sua dignidade, resultando em tratamentos desprendidos de aspectos humanizados.

A informação acerca de tratamentos e procedimentos médico-hospitalares está disponível a todos, profissionais ou sujeitos da conduta médica, e ambos devem decidir juntos, após criteriosa ponderação das consequências, qual será a melhor opção.

Há como decidir de modo completo e permanente, sem acesso à totalidade das informações, com esclarecimentos parciais?

Evidentemente, a ausência de informação torna o sujeito inapto a opinar e decidir. Todavia, apenas informação não é o bastante. Ele deve analisar seus valores enquanto ser humano, não optando por procedimentos que lhe trarão mal maior do que aquele causado pela própria enfermidade.

Toda intervenção que exponha o indivíduo a risco deve ser antecedida pela expressa autorização daquele que se submeterá a essa prática. Para fazer isso de modo consciente e efetivo, é imperioso que o sujeito seja esclarecido acerca dos riscos e benefícios que o procedimento apresenta, bem como de terapias alternativas. $\mathrm{O}$ instrumento capaz de comprovar a autorização e o esclarecimento é o termo de consentimento, o qual deve ser manifestado de forma livre e consciente. Contudo, resta a hipótese de o indivíduo não aceitar ser submetido a tal prática, recusando o tratamento. Neste caso, as diretivas antecipadas de vontade (DAV) permitem que qualquer indivíduo capaz, e em pleno estado de consciência, determine a quais práticas se recusa a ser submetido caso, no futuro, padeça de 
doença terminal, incurável, com quadro clínico irreversível e seu estado não lhe permita manifestar sua vontade.

Foi nesse contexto que surgiu a Resolução n. 1.995/2012 do Conselho Federal de Medicina (CFM), que reconhece a necessidade de respeitar a autonomia do paciente e regulamenta o instituto das diretivas.

Mas quais são as consequências éticas e jurídicas, oriundas da relação médico-paciente, fundamentadas no cumprimento ou descumprimento das diretivas antecipadas de vontade?

No estudo que originou este livro, nos ocupamos desses temas, buscando resposta para essa indagação.

Consideramos que não apenas a vida digna, mas também a morte digna deve ser analisada, mensurando-se a validade do prolongamento artificial de vidas inviáveis, em situações irreversíveis, quando o sujeito está inconsciente, bem como o consentimento esclarecido por meio de instrumento próprio.

A vida é um conjunto de incertezas. A única certeza é seu término, restando ainda incerto em qual momento acontecerá. A morte é o capítulo derradeiro do livro da vida, que todos os autores escreverão, porém resta saber como cada um o fará.

Tendo-se a morte como algo natural e certo, é necessário preservar a relação de respeito e confiança adquirida ao longo da vida, e o maior sinal de respeito à relação médico-paciente é preservá-la mesmo nesse momento.

Seria a morte um inimigo que deve ser combatido a qualquer custo, inclusive com o sofrimento do paciente, ou apenas mais uma etapa da vida, em que a dignidade humana também deve ser defendida?

O respeito ao paciente apenas existe se seus desejos e suas escolhas são acatados. É inadmissível qualquer procedimento em paciente terminal que, com o intuito de prolongar-lhe a vida, apenas amplie seu sofrimento e contribua para dilatar sua morte.

Entretanto, em virtude da própria enfermidade, muitas vezes o paciente, nessa fase terminal, encontra-se impedido de manifestar, de modo consciente e inequívoco, sua vontade de aderir ao 
tratamento ou procedimento proposto, o que causa insegurança, angústia e dor a familiares e profissionais da saúde sobre a decisão a tomar. Pessoas próximas são importantes nesses momentos.

A pesquisa apresentada neste livro teve natureza teórica. Preponderou nela a análise bibliográfica, com a leitura e a análise de publicações que tratam dos aspectos normativos e conceituais relacionados ao tema. O enfoque principal recaiu sobre a importância do consentimento livre e esclarecido dos sujeitos da pesquisa, privilegiando aspectos bioéticos e constitucionais. Também analisamos julgados extraídos de tribunais nacionais e estrangeiros. 


\section{1 \\ CONCEPÇÕES TEÓRICAS SOBRE BIOÉTICA, BIODIREITO E DIGNIDADE HUMANA}

Ética, bioética e dignidade humana são termos que se completam. A ética é um campo do conhecimento humano que apresenta as dimensões territorial e espacial e se modifica de acordo com a sociedade objeto da análise. A bioética é uma ciência inter e multidisciplinar, que aplica os fundamentos éticos às biociências. A dignidade humana remete à aplicação de conceitos éticos e morais visando satisfazer as necessidades elementares do indivíduo. Veremos a seguir, de modo mais extenso, cada um desses conceitos.

\section{Bioética e sua interface com o direito e o biodireito}

A bioética derivou da ética filosófica. Pode ser interpretada como uma espécie de ética aplicada. Seu objeto de estudo e suas reflexões foram sendo ampliados à medida que a tecnologia e a biotecnologia foram se desenvolvendo, em especial a partir de 1970. Assim, a bioética surge como uma ciência, e em razão da complexidade da matéria abordada apresenta características interdisciplinares (Fernandes, 2012).

O avanço tecnológico transformou as relações humanas e antigos conceitos éticos, em razão das novas realidades existentes, o 
que permitiu ao ser humano interferir diretamente na natureza e no próprio indivíduo. Grupos que detêm o conhecimento determinam o modo de agir e intervir na vida dos demais, com consequências para toda a sociedade.

O primeiro estudioso a utilizar o termo "bioética" foi Fritz Jahr, em 1927, na Alemanha, no título de um artigo de sua autoria publicado na revista Kosmos. Jahr desenvolveu a ideia de "imperativo bioético: respeita cada ser vivo em princípio como uma finalidade em si e trata-o como tal na medida do possível" (Fernandes, 2012).

Contudo, quem primeiro referiu-se à bioética como campo de estudo foi o oncologista Van Rensselaer Potter, em 1970, em artigo publicado na revista Perspectives in Biology and Medicine, que recebeu o nome de "Bioethics: the science of survival". No ano que se seguiu, esse artigo transformou-se no primeiro capítulo de seu livro Bioethics: bridge to the future.

Potter justifica a escolha do termo, pela justaposição do radical "bio", que se refere aos seres vivos e às ciências biológicas, e de "ética", que se refere ao conjunto de valores humanos.

A complexidade é inerente à proposta bioética, uma vez que envolve questões éticas presentes em uma coletividade heterogênea social e culturalmente. O objetivo da bioética é analisar os dilemas humanos no ambiente em que estão inseridos (Fernandes, 2012).

Além de ter criado o termo "bioética", outra grande contribuição de Potter foi ter percebido que o avanço das biociências, devido ao crescente número de pesquisas que já havia naquele momento, poderia levar a inovações prejudiciais à sobrevivência humana. Ao mesmo tempo, eram grandes as perspectivas de suas relevantes contribuições para a qualidade de vida humana, porém existia o risco de consequências imensuráveis para os indivíduos e o ecossistema.

Outra importante contribuição para a solidificação do termo e, principalmente, da ciência foi oferecida por André Hellegers, médico obstetra holandês, fundador do Kennedy Institute of Ethics, que percebeu que a evolução da bioética, enquanto ciência, estava no constante diálogo e confronto entre a ética, a filosofia e a medicina, confirmando que os aspectos éticos devem ser analisados na 
prática médica. Hellegers também notou que a bioética necessitava de uma metodologia própria, interdisciplinar, capaz de associar os diversos ramos do conhecimento humano, com vistas a promover a prática das pesquisas e dos procedimentos biomédicos, obedecendo a preceitos éticos e valores morais (Sgreccia, 2009).

Desse modo, seguindo a linha de Potter, de início a bioética foi considerada a "ciência da sobrevivência" em um sentido ecológico, que disciplinaria a relação do ser humano com a natureza, interagindo de forma harmoniosa, visando a melhoria das condições de vida, por meio das ciências biológicas, garantindo a sobrevivência no planeta de modo equilibrado, com o fim de preservar os ecossistemas existentes.

Em momento posterior, o termo passou a ser empregado para designar a ética biomédica, a ética das ciências da vida.

Na Encyclopedia of bioethics, Reich (1978) conceitua bioética como "[...] o estudo sistemático das dimensões morais das ciências da vida e do cuidado da saúde, utilizando uma variedade de metodologias éticas num contexto multidisciplinar".

O diretor do centro de bioética da Universidade de Montreal, David J. Roy (1979), definiu-a como um estudo interdisciplinar de todas as condições para que a vida humana seja administrada de modo responsável, em razão da celeridade e da complexidade do conhecimento e da tecnologia biomédica.

A complexidade dos temas abordados pela bioética, inseridos em uma sociedade heterogênea, associada ao seu objetivo de solucionar os dilemas humanos, fez surgir a necessidade de aglutinar diversas disciplinas, como ética, filosofia, medicina, sociologia, biologia, direito, economia, antropologia, para que seu fim seja alcançado (Fernandes, 2012).

Por essa razão, a bioética e a sua conexão com o direito exigem a utilização do método interdisciplinar, de modo a promover a interação entre conceitos e experiências de diversas disciplinas, estabelecer uma conjunção das diversas formas de conhecimento, desenvolver um consenso geral entre os ramos do conhecimento humano, ampliar os conceitos preexistentes por meio de um ca- 
minho racional, almejando retomar o pensamento humanista e universal (Fernandes, 2012).

Atualmente, o termo bioética se refere à ética existente nas relações médicas, nas ciências da vida, na biotecnologia, na engenharia genética, na embriologia, na ecologia e nas tecnociências. É responsável por estabelecer controles éticos em temas polêmicos, como o aborto, a eutanásia, a clonagem, a reprodução assistida, a eugenia, técnicas de biologia molecular com utilização de DNA (como a transgenia), entre outros.

Segundo Clotet (2003), "bioética é uma ética aplicada, que se ocupa do uso correto das novas tecnologias na área das ciências médicas e da solução adequada dos dilemas morais por elas apresentados", ou ainda, de acordo com Potter (1988), "bioética é uma nova ciência ética que combina humildade, responsabilidade e uma competência interdisciplinar, intercultural e que potencializa o senso de humanidade".

Para Marchetto (2010), é muito importante identificar o objeto de análise da bioética, pois o estudo bioético é desenvolvido para tutelar a vida e o modo de viver. Este, inclusive, para a bioética é superior à própria vida, merecendo especial atenção. A qualidade de vida deve ser preservada e defendida, pois esta é a determinação constitucional expressa no princípio da dignidade humana, razão pela qual o constante progresso atingido pelas ciências biológicas deve estar sob vigilância. Afinal, proporciona melhora substancial da qualidade de vida da população, promovendo a dignidade humana. Contudo, as preocupações não se restringem ao modo de viver, influenciando, inclusive, o modo e a qualidade da morte.

A ética é um dos ramos da filosofia, que tem a bioética como uma de suas derivações. Estuda as questões atreladas à vida humana, e seu principal objeto de estudo é a vida, bem como a morte, por ser esta uma consequência obrigatória da primeira (Segre, 2002).

O conhecimento jurídico e a tecnologia evoluem em modo e velocidade distintos, cada qual respeitando suas características.

Acredita-se que a ética contemporânea tenha seu marco inicial na metade do século XIX. Atualmente, algumas dicotomias estão pre- 
sentes nela, tais como o antigo formalismo e universalismo, substituídos pelo indivíduo concreto, real; o racionalismo absoluto, substituído pelo comportamento humano irracional; e a origem do ser humano, antigamente ligada de modo direto ao transcendental, ao metafísico, substituída pela origem própria, biológica, evolutiva (D'Assumpção, 1998).

Jean Paul Sartre (2008), principal expoente do existencialismo, considerava que é a existência do ser a responsável pela sua essência. O ser humano é definido pelos seus objetivos, porque assim determina a natureza humana. A vontade é determinante da conduta humana, e também o seu limite. A autonomia permite que a pessoa escolha sua conduta, sem qualquer forma de submissão. Sendo assim, os objetivos de um indivíduo vão caracterizar o que ele realmente é.

A ética e o direito se relacionam ao longo do tempo, complementam-se, e é essa relação, aliada às ciências biológicas, que conduz à bioética da responsabilidade, decorrente de sua aplicação prática.

Ciência e tecnologia evoluem constantemente e em ritmo muito acelerado na época atual. Esses são dois campos do conhecimento humano que estabelecem relações um com o outro e também com a realidade da população, influenciando seu cotidiano. A ciência se identifica com a necessidade do ser humano de saber, compreender, analisar, explicar, prever ou evitar os fenômenos da natureza, enquanto a tecnologia surge de outra necessidade: a de buscar outros modos de satisfazer as necessidades humanas, para o que se faz necessária a utilização de ferramentas, de conhecimentos prévios, de recursos naturais e até mesmo de energia (Sarlet, 2007).

$\mathrm{O}$ avanço da ciência, em especial da biotecnologia, influencia a vida das pessoas e gera polêmicas. Mostra-se necessário, pois, um regramento específico, que delimite a atuação dos profissionais e proporcione ao sujeito da pesquisa ou da intervenção informações a respeito do procedimento a que será exposto, de suas consequências, de seus riscos e benefícios. Mais do que isso, após a análise criteriosa dos dados, ele deve concordar em se submeter à intervenção, para superar injustiças e proteger o bem jurídico mais importante: a vida humana digna. 
É imperioso ressaltar que a bioética não tem o papel de dificultar o avanço e o desenvolvimento da ciência. Ao contrário, deve demonstrar as mínimas exigências para assegurar que esse desenvolvimento biotecnológico, que rompe com paradigmas e valores assegurados e reconhecidos pela humanidade, seja compatibilizado com essa nova realidade e com os novos conhecimentos e procedimentos científicos (Hironaka, 2003).

Desse modo, pode-se afirmar que a bioética nada mais é do que a associação das reflexões morais e filosóficas a respeito da vida como um todo e, em particular, a respeito das práticas médicas. Aí devem ser incluídas também as pesquisas de caráter multidisciplinar que envolvam as áreas da filosofia, antropologia, psicologia, sociologia, teologia, medicina, genética, farmácia, biologia, ecologia, política, direito e todas as demais que busquem oferecer soluções para problemas individuais ou metaindividuais relativos à genética, biotecnologia, biologia molecular, medicina, embriologia, bem como aos demais temas que envolvam o ser humano, como objeto ou destinatário do estudo que verse sobre a saúde, a vida, a qualidade de vida, a morte, a qualidade de morte, a personalidade, a identidade e a integridade psicofísica, por meio de uma análise e tutela ética. O direito é a ciência responsável por estabelecer limites aos avanços biotecnológicos, impondo barreiras capazes de salvaguardar os direitos fundamentais dos indivíduos, preservando-os, inclusive, para as gerações futuras. A bioética pode ser considerada o estudo da moral, inserida na conduta humana, na área das ciências biológicas, analisando a licitude das condutas e a possibilidade técnica e científica dos procedimentos (Diniz, 2002).

A bioética é a uma arma importantíssima na luta pela valorização da vida humana, da sua dignidade, da liberdade, frente ao biopoder, impedindo a eugenização e a coisificação do ser humano. São inevitáveis os debates científicos, políticos e jurídicos que a envolvem, uma vez que se encontra em constante transformação, especialmente nos dias atuais, com temas que envolvem ideologias, com valores e identificação cultural (Lucrezi, 2010). 
As suas preocupações principais são: a prudência no agir humano; a postura ética como base para a conduta de usuários e profissionais biomédicos; os critérios jurídicos que salvaguardem a liberdade humana, a dignidade, a segurança e o bem-estar social.

Os direitos humanos são direitos históricos, que originalmente a doutrina dividiu em três dimensões. A primeira dimensão é caracterizada por direitos que fundamentam a liberdade; a segunda, por direitos que fundamentam a igualdade; a terceira, por direitos que fundamentam o ideal de solidariedade ou fraternidade (Bobbio, 1997).

Anteriormente, os direitos humanos eram conhecidos como direitos do homem, pois são inerentes à natureza humana, referentes a qualquer representante da espécie, não constituindo privilégio de um indivíduo ou grupo determinado (Comparato, 2010).

O avanço do conhecimento humano fez surgir práticas e produtos que alteraram a vida humana e não estão contemplados em nenhuma das tradicionais dimensões mencionadas.

A sociedade passou a evoluir em um ritmo acelerado, com alteração de paradigmas e de práticas científicas e tecnológicas. Nesse contexto, surgiram os direitos humanos de quarta dimensão, que fundamentam especificamente a evolução biotecnológica e a regularização das modificações derivadas dessa nova realidade.

Os direitos de quarta dimensão são o direito à informação, à democracia e ao pluralismo, e depende deles a consolidação de uma sociedade próspera, futurista e universal (Bonavides, 2007).

Atualmente, as discussões sobre o início e a terminalidade da vida, além de manipulação genética e biotecnologia, inserem-se no rol dos direitos humanos de quarta dimensão, uma vez que implicam o respeito aos preceitos éticos e jurídicos.

Os problemas decorrentes da evolução biotecnológica devem ser tutelados pela ordem jurídica, e para isso é imperioso estabelecer limites às novas práticas médico-hospitalares, para o desenvolvimento de pesquisas e a utilização dos dados obtidos (Lima Neto, 1998).

A liberdade do avanço científico é relativa, já que pode colidir com outros valores extremamente relevantes, tais como a dignidade 
humana, a integridade física e psíquica ou a própria vida. Todos esses bens jurídicos são protegidos juridicamente, o que denota um conflito de valores. Daí a necessidade de regulamentar práticas dessa natureza, por meio de um regramento próprio, que reconheça as características especiais que envolvem o conflito entre avanço biotecnológico e direitos fundamentais.

Sempre se busca a regulamentação da lei, porque ela é instrumento pelo qual os valores são preservados. A ciência jurídica é responsável por organizar a conduta de cada indivíduo, desse modo o direito desempenha a função de organizar as liberdades e promover a educação a valores relevantes (Leite, 1998).

Diante de tais necessidades, surgiu o biodireito, conceituado por Jussara Suzi de Assis Borges Nasser Ferreira (1998-1999) como o conjunto de normas esparsas que visa regular as práticas e interações entre as biociências e as biotecnologias, objetivando preservar a dignidade humana e a integridade física e moral expostas ao progresso, o qual promove conquistas científicas que podem beneficiar ou não a vida humana.

Para que a ordem jurídica consiga promover essa tutela, é imperioso que seus preceitos sejam associados aos princípios bioéticos e aos direitos fundamentais, estabelecendo assim o regramento do biodireito.

A transição da bioética, que já foi efetivada, para um novo ramo da ciência jurídica, conhecido como biodireito, não é tarefa fácil, exige grande reflexão e ponderação dos valores envolvidos. O biodireito não pode ser reduzido apenas à função instrumental. Deve-se dar a ele maior amplitude, sem deixar de tutelar interesses específicos (Barboza, 2000).

A bioética é precedente, pois permitiu o desenvolvimento do biodireito e simultaneamente auxilia o desenvolvimento de sua práxis, ao estabelecer parâmetros concernentes à realidade. Bioética e biodireito visam a tutela dos direitos humanos fundamentais, porém por meio de abordagens distintas, mas que se complementam axiológica e socialmente (Sá, 2009). 
Acredita-se que o biodireito tenha surgido no ano de 1969, por meio da atuação do filósofo Daniel Callahan e do psiquiatra Wilard Gaylin, que receberam denúncias de abusos em pesquisas envolvendo seres humanos. Após tomarem ciência das violações, levaram os fatos ao conhecimento da comunidade acadêmica, surgindo então as primeiras reflexões nesse sentido.

Inegavelmente, o desenvolvimento biotecnológico e da ciência médica fez surgir inúmeros fatos e práticas até então inimagináveis, que passaram a ser fruto de questionamentos de natureza ética e jurídica. O biodireito derivou da preocupação dos operadores das ciências biológicas com as consequências éticas e jurídicas de suas condutas (Sá, 2009). Trata-se de uma disciplina que apresenta diversas faces, como a preocupação com a vida, o nascimento, o desenvolvimento e a transformação do ser humanno, as relações intersubjetivas e a relação entre saúde e doença, bem como as relações entre o indivíduo e o meio ambiente (Parise, 2003).

Há normas com conteúdo afeito ao biodireito na Constituição Federal, responsável por reconhecer e efetivar as garantias e os direitos fundamentais, como a dignidade da pessoa humana, a privacidade, a saúde e a própria vida humana. Isso também ocorre com o Código Civil, ao dispor sobre os direitos de personalidade, com normas que regulam desde o nascimento com vida, disposições sobre o próprio organismo, o nome, a condição sexual e todas as outras condições referentes ao ser humano que se estendem ao longo da sua vida e continuam após a morte. As normas penais, responsáveis por aplicar sanções no caso de infrações como a violação à integridade física, psíquica e moral de outrem, ou em casos mais extremos, em que é dado fim à vida humana, também não podem ser esquecidas.

O biodireito percorre, portanto, um caminho estreito que baliza o confronto entre o respeito às liberdades individuais e a proibição de abusos contra o indivíduo ou de toda a espécie humana (Sauwen, 1997).

Maria Cristina Couto Scofano (2006) esclarece que o biodireito é um dos ramos do direito mais afeito a mudanças, além de estabelecer relações diretas com outros ramos do conhecimento humano, 
contudo não deve basear-se em fundamentos antigos, mas buscar novos horizontes, por meio de uma visão ampla e complexa da realidade. Deve ter características pluralistas, promovendo a justiça real ante o impacto das mudanças. A evolução biotecnológica gera modificações, e o direito é o responsável por estabelecer o equilíbrio nas relações humanas.

André-Jean Arnaud (1999) define biodireito como um ramo do direito que se ocupa da teoria, do conjunto de leis e da jurisprudência referentes à relação entre a conduta humana e as normas que a regulam frente aos avanços da ciência médica, biológica e biotecnológica.

Maria Helena Diniz (2002) conceitua biodireito como o estudo jurídico que tem como fontes imediatas a bioética e a biogenética, cujo objeto principal é a vida. Estabelece que o avanço científico não pode superar os princípios éticos e jurídicos, nem permitir violações à dignidade humana, ou mesmo modificar o futuro da humanidade, sem obedecer aos limites jurídicos.

A bioética e o biodireito são institutos distintos e complementares. O biodireito auxilia nas discussões sobre bioética e biomedicina, cabendo à comunidade jurídica, à comunidade acadêmica e à sociedade cumprir as determinações legais, os princípios normativos, os direitos e as liberdades fundamentais e os direitos humanos, que são a pedra angular do Estado democrático de direito.

\section{A bioética principialista inspirada pelo Belmont Report}

A evolução da bioética recebeu grande contribuição da família Kennedy, que percebeu a necessidade de financiar pesquisas com pessoas portadoras de necessidades especiais, em razão de doença mental congênita. Essa pesquisa serviu de estímulo para a criação de um instituto voltado para a fisiologia da reprodução e para a bioética, dando origem, em 1971, ao The Joseph and Rose Kennedy Institute for the Study of Human Reproduction and Bioethics. Posteriormente, em 1979, a instituição foi anexada à Georgetown University e passou a ser denominada Kennedy Institute of Ethics (Sgreccia, 2009). 
O Kennedy Institute of Ethics, por meio de suas pesquisas, aproximou a bioética das condutas médicas, contribuindo de modo determinante para o desenvolvimento dessa nova ciência.

Importantes pesquisadores tiveram produção associada ao Kennedy Institute of Ethics, em especial a obra de T. L. Beuchamp e J. F. Childress, autores de Principle of biomedical ethics, fundamental para o principialismo bioético, como será demonstrado.

O desenvolvimento da bioética como ciência fez surgir a necessidade de elencar os princípios fundantes desse novo ramo do conhecimento humano. Preocupado com essa questão, entre os anos de 1974 e 1978, o Congresso norte-americano instituiu a National Commission for the Protection of Human Subjects of Biomedical and Behavioural Research com o objetivo de superar conflitos éticos e descrever quais princípios norteariam as pesquisas e os procedimentos envolvendo seres humanos. Como resultado do trabalho dessa comissão, foi apresentado o relatório denominado Belmont Report, que estabeleceu que a bioética deve se pautar em três princípios fundamentais que valorizam a pessoa humana, surgidos com base nas necessidades individuais e na natureza humana: justiça, beneficência e autonomia (Sgreccia, 2003).

O princípio da autonomia estabelece que a vontade do paciente deve ser respeitada pelo profissional da saúde, assim como as suas convicções existenciais, como religião e valores morais. Também deve ser respeitada sua intimidade, devendo-se levar em conta suas intenções com o tratamento, sem fazer uso de meios que lhe provoquem constrangimentos.

A autonomia consiste na capacidade do indivíduo de atuar de modo independente, com conhecimento, sem influência ou coação externa. Em razão desse princípio, surge a obrigatoriedade da manifestação do consentimento livre e informado (Diniz, 2002).

Pode-se afirmar que o respeito à pessoa, a suas convicções, seus valores morais e suas crenças é parte integrante da autonomia, que só pode ser exercida em um ambiente livre de intromissão. Deve-se agir de modo consciente, sem sofrer qualquer espécie de constrição. 
A autonomia pode ser considerada mais do que um princípio, mas um verdadeiro estatuto bioético, pois na sua ausência todos os demais princípios estariam mitigados, visto que a liberdade é o elemento mínimo para qualquer conduta lícita. Baseia-se no primado da moralidade e do respeito mútuo.

O princípio da beneficência consiste na busca pelo bem-estar sem causar danos à saúde física e mental do paciente. Baseado nos ensinamento de Hipócrates, estabelece que todos os tratamentos devem ser usados para a cura da enfermidade, nunca para causar-lhe outro mal ou dano. A beneficência é uma ação feita para o benefício de outrem, para proporcionar-lhe o maior bem possível, sem causar-lhe mal.

O benefício deve ser o objetivo de toda pesquisa e de todo procedimento que envolva seres humanos. Não há razão para dispor de recursos técnicos, científicos ou monetários a não ser para proporcionar benefícios ao indivíduo. Não praticar um malefício não é suficiente. Deve-se promover algum ganho na qualidade de vida. Todavia, prevenir ou evitar um mal futuro é sinal de respeito ao princípio da beneficência.

O benefício implica a consecução do seu fim, que é alcançar efetivamente um bem. No caso da benevolência, basta o desejo ou a intenção de obter um resultado favorável (Sgreccia, 2009). Por isso, o termo "benefício" é considerado mais adequado do que "benevolência", também comumente usado.

O princípio da justiça consiste na máxima aristotélica de tratar igualmente os iguais, com imparcialidade, com proporcionalidade na distribuição dos tratamentos. Deve existir uma relação equânime nos riscos, nos encargos e nos benefícios no tratamento da saúde do paciente.

Tratamento igualitário significa disponibilizar a prática dos resultados das pesquisas em favor da sociedade, distribuir as verbas disponíveis para pesquisa de modo justo, a fim de assegurar sua realização e o aprimoramento do conhecimento científico. A evolução biotecnológica possibilita que novos procedimentos sejam desenvolvidos, o que amplia as perspectivas de melhoria das con- 
dições de vida da população. Assim, esses procedimentos devem estar ao alcance daqueles que deles necessitam.

O princípio da justiça não defende que todos sejam tratados de modo idêntico, mas aqueles que possuem as mesmas necessidades devem receber as mesmas oportunidades. A ciência evolui com o fim de promover a melhoria da qualidade de vida da população, e não é correto eleger um grupo para ser o destinatário único dos melhoramentos conquistados.

Os benefícios devem ser distribuídos de modo equânime, sem que haja qualquer espécie de discriminação ou favorecimento, e as melhorias devem ser promovidas de modo impessoal.

Posteriormente, esse rol de princípios foi ampliado. Em 1979, Tom L. Beauchamp e James F. Childress (2009) publicaram a obra Principles of biomedical ethics, na qual foi incluído um novo princípio, denominado de não maleficência. Este princípio consiste em não cometer um dano intencional e sempre levar em conta a ética médica, podendo ser considerado complementar ao princípio da beneficência. Impõe ao agente o dever de se abster de causar ou agravar intencionalmente a condição do sujeito da pesquisa ou do procedimento que envolva seres humanos, afinal essa conduta lesiva é uma afronta à ética, à moral e à dignidade humana.

Esse conjunto de princípios, de origem norte-americana, recebeu o nome de principialismo e teve grande importância para os estudiosos da bioética, servindo inclusive como paradigma ético para todos que trabalham na área da saúde. É considerado referência prático-profissional que auxilia e justifica decisões a serem tomadas (Sgreccia, 2009).

$\mathrm{O}$ avanço da bioética mostrou que essa visão principialista necessita sofrer modificações, porque há outros valores a tutelar e por ser muito simplista e restringir uma ciência multifacetada, como a bioética, a um diminuto grupo de princípios.

Nesse contexto, a bioética evoluiu, novas modalidades de tutela passaram a ser debatidas e conquistaram espaço nessa ciência multidisciplinar. 


\section{A Declaração Universal sobre Bioética e Direitos Humanos: um modo mais humano de interpretação}

A Organização das Nações Unidas para a Educação, a Ciência e a Cultura (Unesco) percebeu a necessidade de elaborar um documento para normatizar as condutas sobre bioética e direitos humanos em âmbito universal.

A ideia foi apresentada na Mesa Redonda de Ministros da Ciência sobre Bioética, em outubro de 2001. Na mesma oportunidade, foi ratificada, e o diretor-geral da Unesco foi convidado a elaborar um estudo técnico que demonstrasse a viabilidade de uma normativa universal sobre bioética.

O International Bioethics Committee (IBC) foi incumbido de realizar o estudo, e no período de dois anos ocupou-se da tarefa que lhe foi confiada. Em 2003, apresentou o relatório final, concluindo ser viável a elaboração do documento universal sobre bioética, conclusão que em seguida foi confirmada pelo Intergovernmental Bioethics Committee (IGBC) (Unesco, 2005).

Posteriormente, o IBC elaborou uma versão preliminar do texto, estruturada em três fases: consulta ampla acerca dos objetivos e da estrutura da normativa aos principais atores (estados, comitês nacionais de bioética, organismos intergovernamentais, organizações não governamentais e especialistas nacionais); elaboração de um documento preliminar, baseado nas consultas; elaboração do texto definitivo, com o auxílio de peritos governamentais.

Outras agências das Nações Unidas também auxiliaram na elaboração das consultas. A Unesco ainda organizou conferências com diversos especialistas em muitos países, como Argentina, Coreia do Sul, Holanda, Indonésia, Portugal, Rússia e Turquia, entre outros.

Com o término das consultas e a elaboração do documento prévio da normativa, após diversos encontros e consultas internas, nacionais e internacionais, o instrumento preliminar da Declaração foi elaborado.

A Unesco determinou a realização de duas reuniões, com peritos indicados pelos países membros. Elas aconteceram em 2005, 
sendo que a segunda contou com a participação de especialistas de noventa países, o que culminou com a adoção da Declaração Universal sobre Bioética e Direitos Humanos (DUBDH) (Unesco, 2005).

A Universal Declaration on Bioethics and Human Rights teve sua elaboração marcada por um exaustivo debate. Seu texto contém vinte e oito artigos, estruturados em seis partes, divididas em: Preâmbulo, Disposições gerais, Princípios, Aplicação dos princípios, Promoção da declaração e Disposições finais.

A Declaração é um documento de conteúdo principiológico que estabeleceu as linhas mestras dentro das quais será lícito aos países definir normas que versem sobre questões bioéticas.

O texto apresenta cláusulas gerais, que conferem ao intérprete a missão de adequar a norma à realidade, e ao aplicador, a de delimitar seu verdadeiro alcance e sentido, contudo a interpretação respeitará os limites estabelecidos pelos direitos humanos e por valores éticos.

Para efetivação do conteúdo desses princípios, é fundamental que o intérprete seja dotado de valores humanísticos, pois desempenha função essencial para o sucesso da Declaração Universal sobre Bioética e Direitos Humanos.

\section{Os princípios da Declaração Universal sobre Bioética e Direitos Humanos e sua relação com a Resolução n. 466/2012 do Conselho Nacional de Saúde}

O respeito ao ser humano é a essência da Declaração Universal sobre Bioética e Direitos Humanos e se manifesta nestes quinze princípios que a compõem: dignidade humana e direitos humanos; benefícios e danos; autonomia e responsabilidade individual; consentimento; pessoas incapazes de consentir; respeito pela vulnerabilidade humana e sua integridade pessoal; vida privada e confidencialidade; igualdade, justiça e equidade; não discriminação e não estigmatização; respeito pela diversidade cultural e pelo pluralismo; solidariedade e cooperação; responsabilidade social e saúde; 
compartilhamento dos benefícios; proteção das gerações futuras; proteção do meio ambiente, da biosfera e da biodiversidade (Unesco, 2006).

No Brasil, o Conselho Nacional de Saúde (CNS), em sua 240a Reunião Ordinária, realizada no mês de dezembro de 2012, aprovou a Resolução n. 466/2012, que foi publicada em 13 de junho de 2013 no Diário Oficial da União. A resolução versa sobre pesquisas e testes em seres vivos e substituiu a Resolução n. 196/1996, a primeira a tratar o tema.

A resolução estabelece diretrizes éticas e científicas semelhantes àquelas abordadas na Declaração Universal sobre Bioética e Direitos Humanos, incorporando referenciais bioéticos relevantes, como a autonomia, a beneficência, a não maleficência e a equidade, dentre outros, cujo escopo é assegurar os direitos dos sujeitos da pesquisa (Conselho Nacional de Saúde, 2014).

A Declaração Universal sobre Bioética e Direitos Humanos foi determinante para a elaboração da Resolução n. 466/2012, que aborda no item III os aspectos éticos da pesquisa, enquanto o diploma internacional faz referência à dignidade humana e aos direitos humanos, o que demonstra a preocupação desse instrumento normativo com relação às garantias e às liberdades fundamentais, em sua totalidade. Mais que isso, visa assegurar que os interesses do indivíduo e o seu bem-estar tenham prioridade em relação ao interesse exclusivo da ciência ou da sociedade.

A Declaração também busca assegurar que os benefícios diretos e indiretos devem ser maximizados. Este princípio é uma nítida herança dos ensinamentos conquistados por meio do Belmont Report, em clara alusão ao princípio da beneficência, igualmente reconhecido no item V da Resolução n. 466/2012. Contudo, não basta a existência de benefícios. É fundamental a minimização de qualquer dano possível, em especial quando advém da aplicação e do avanço do conhecimento científico, ou mesmo de práticas médico-hospitalares, bem como de tecnologias associadas, outra evidente referência ao principialismo bioético e ao princípio da não maleficência. 
O indivíduo é o principal ator nas relações bioéticas e jurídicas e, por essa razão, a Declaração Universal sobre Bioética e Direitos Humanos impõe que a autonomia deve ser respeitada. A pessoa será livre para decidir sempre que sua responsabilidade individual puder ser considerada e sua conduta individual respeitar a autonomia dos demais. Aqueles que não são capazes de exercer sua autonomia devem receber proteção, por meio de medidas especiais, para garantir seus direitos e interesses.

A autonomia do indivíduo só pode ser respeitada quando qualquer procedimento médico preventivo, diagnóstico ou terapêutico é antecedido por uma manifestação de vontade, por um consentimento livre e esclarecido dele. Para que o consentimento seja válido, é fundamental que a informação seja adequada, pois só assim o sujeito será capaz de consentir.

$\mathrm{O}$ indivíduo pode manifestar seu consentimento ou retirá-lo a qualquer momento, independentemente de justificativas, sem sofrer qualquer prejuízo ou preconceito em razão de sua atitude.

Esse princípio comporta exceções apenas quando os fatos concretos exigem sua relativização. A conduta deve seguir os padrões legais e éticos impostos pela sociedade local e estar em comunhão com as disposições da Declaração e com os direitos humanos.

A Declaração Universal sobre Bioética e Direitos Humanos dispôs sobre os indivíduos incapazes para consentir, hipótese em que deve haver especial proteção à autorização, que deve ser obtida vislumbrando o real e melhor interesse do sujeito, respeitando a legislação nacional. Dentro dos limites de sua capacidade, o indivíduo que será exposto à prática médica ou à pesquisa deverá participar do processo de decisão sobre consentimento, bem como de sua retirada.

A autonomia também recebeu atenção especial na Resolução n. 466/2012, que dedicou o item IV ao termo de consentimento livre e esclarecido, com todas as suas particularidades, inclusive com referência aos indivíduos incapazes para consentir, inovando ao reconhecer, no item c. 2 , a diretiva antecipada de vontade como modalidade de consentimento livre e esclarecido. 
O respeito pela vulnerabilidade humana e pela integridade individual também mereceu especial atenção do diploma internacional, que prescreveu que a vulnerabilidade humana será considerada na aplicação do conhecimento científico, das práticas médicas e de tecnologias associadas, bem como no seu desenvolvimento.

Pessoas ou grupos de vulnerabilidade específica são merecedores de proteção, referente à integridade individual, ou às necessidades específicas de cada grupo.

Todo sujeito exposto à prática médica ou à pesquisa deve ter sua privacidade e a confidencialidade das informações respeitadas. As informações não devem ser utilizadas para fins diversos daqueles para os quais foram coletadas de modo consentido, nem reveladas para terceiros que não participam do processo, com respeito à legislação e aos direitos humanos.

Outra evidente homenagem da Declaração Universal ao Belmont Report é a preocupação em defender a igualdade, a justiça e a equidade.

Não existe dignidade ou ordem jurídica sem a prescrição e a busca pela efetivação da igualdade fundamental entre as pessoas. Todos merecem ser tratados de forma justa e equitativa.

O diploma internacional prevê a não discriminação e a não estigmatização, pois nenhuma razão é capaz de ensejar a discriminação ou a estigmatização de uma pessoa ou de um grupo. Essa conduta é uma evidente afronta à ordem jurídica, aos direitos humanos, às liberdades fundamentais e à dignidade humana.

O respeito pela diversidade cultural e pelo pluralismo recebeu da Declaração Universal sobre Bioética e Direitos Humanos a necessária consideração. Contudo, a diversidade cultural e o pluralismo não podem ser instrumento de violação de liberdades fundamentais, da dignidade humana e dos direitos humanos.

O diploma universal estabeleceu que a solidariedade humana e a cooperação internacional devem ser estimuladas e seu desenvolvimento deve ser incentivado.

A responsabilidade social e a promoção da saúde são defendidas pela Declaração por acreditar-se que esses elementos devem ser o 
fim do Estado, em comunhão com o desejo da sociedade, pois são direitos fundamentais de todo ser humano, independentemente de etnia, inclinação política, credo ou condição socioeconômica.

O desenvolvimento biotecnológico deve promover a acessibilidade aos cuidados de saúde de modo integral, pois a saúde é essencial à vida. Constitui um bem social, além de ser considerada um direito fundamental.

A Declaração Universal sobre Bioética e Direitos Humanos se preocupa com o compartilhamento de benefícios, o que pode ser considerado uma extensão dos princípios da beneficência e da justiça, previstos no principialismo bioético. Esse princípio prevê que os benefícios adquiridos por meio de pesquisas sejam compartilhados com a toda a sociedade, promovendo o acesso aos cuidados de saúde, novas modalidades diagnósticas e terapêuticas ou de produtos, de serviços de saúde.

A proteção às gerações futuras é outra importante preocupação da Declaração Universal. Afinal, o desenvolvimento das biociências produz impacto sobre a vida das futuras gerações, influenciando inclusive sua constituição genética, razão pela qual merece proteção.

O último princípio elencado na Declaração Universal sobre Bioética e Direitos Humanos é a proteção do meio ambiente, da biosfera e da biodiversidade. Esta proteção diz respeito à íntima relação que existe entre o ser humano e as demais formas de vida. $\mathrm{O}$ indivíduo não existe isoladamente. É imprescindível à vida humana a utilização dos recursos biológicos, e para isso a biosfera e a biodiversidade obrigatoriamente precisam ser preservadas.

\section{Princípio da dignidade da pessoa humana}

O respeito à dignidade da pessoa humana é tema de grande importância para o direito e a bioética, bem como para a própria vida e, por que não?, para a morte digna. Vamos analisar a validade do emprego de técnicas científicas para o prolongamento artificial da vida, 
fornecendo uma contribuição jurídica e uma reflexão sobre a importância dessa valiosa garantia constitucional.

O termo "pessoa" possui diferentes acepções, nas diferentes áreas do conhecimento. No sentido técnico-jurídico, refere-se a todo ser capaz de contrair obrigações, sujeito de direitos e deveres, diferenciando-se de coisa, que é o objeto da relação jurídica. $\mathrm{O}$ indivíduo apenas se torna pessoa por meio da investidura da personalidade (Silva, 1991). A Magna Carta, ao definir o princípio da dignidade da pessoa humana, atribuiu o valor semântico de ser humano ao vocábulo "pessoa", não o sentido previsto na lei civil, restrito apenas aos indivíduos capazes de contrair obrigações. $\mathrm{O}$ art. 2 o afirma que a personalidade tem início com o nascimento com vida, e o ordenamento jurídico garante os direitos do nascituro. $\mathrm{O}$ exercício desses direitos está subordinado a uma condição: o nascimento com vida (Monteiro, 2001).

A Constituição Federal é ainda mais abrangente: ao tutelar a dignidade da pessoa humana, estende sua proteção a toda a humanidade, tenha o indivíduo personalidade, adquirida pelo nascimento com vida, seja o nascituro, cujos direitos apenas serão exercidos após o seu nascimento com vida.

A fonte ética dos direitos, das liberdades e das garantias pessoais, sociais, culturais e econômicas é a dignidade de todas as pessoas. $\mathrm{O}$ ser humano está inserido em um mundo plural, que sofre constantes mutações e conflitos, cujos interesses e desafios são antagônicos. Sendo assim, somente por meio da dignidade da pessoa humana é possível estabelecer as ponderações necessárias ao equilíbrio dos diferentes interesses (Miranda, 2003).

O princípio da dignidade da pessoa humana não possui um conceito fixo e definitivo, uma vez que pode ser considerado uma categoria axiológica aberta a diversas interpretações e conceituações (Sarlet, 1998).

A impossibilidade de fixar esse conceito decorre do fato de que a dignidade da pessoa humana não constitui somente um direito subjetivo, mas trata-se de uma qualidade inerente ao ser humano e universal, que independe de fatores externos, sociais ou geográficos, 
tais como etnia, condição socioeconômica, condição sexual, idade ou qualquer outro. A dignidade não surge em razão da ordem jurídica, esta apenas a reconhece e protege contra violações de qualquer natureza (Novelino, 2008).

O princípio da dignidade da pessoa humana pode ser considerado o núcleo axiológico constitucional. Influenciou todo o ordenamento jurídico, com seus valores e efeitos. Segundo esse princípio, o ser humano deve ser respeitado, acima de todos os outros interesses. Protegê-lo é a razão primordial do Estado e do direito (Sarmento, 2002).

Desse modo, a dignidade da pessoa humana deve ser considerada como o principal valor humano e deve contagiar todas as demais normas do ordenamento jurídico, sem distinção de qualquer natureza entre os indivíduos. Como é a mesma em todos os lugares e para todas as pessoas, cabe ao ordenamento jurídico promovê-la, tutelá-la e garantir sua efetivação por meio de normas jurídicas infraconstitucionais (Novelino, 2008).

A dignidade humana, valor essencial da pessoa no plano jurídico, pode ser considerada a razão de diversos direitos fundamentais, como o próprio direito à vida, assim como o direito à liberdade, à igualdade, à integridade física e psíquica. Para que o ser humano exerça sua cidadania, é preciso que suas necessidades mínimas sejam satisfeitas. As condições elementares para o equilíbrio físico, mental e social devem ser garantidas. Esse direito ao mínimo existencial não constará expressamente na ordem jurídica constitucional, mas deve ser reconhecido e tutelado, porque é o cerne dos direitos fundamentais e seu conteúdo diz respeito às condições mínimas para a vida humana. A dignidade humana não pode ser conceituada ou mesmo elencada em um rol de direitos, em razão de sua mutabilidade temporal e geográfica (Barroso, 2010).

Flávia Piovesan (1999) assevera que toda Constituição deve ser interpretada como um conjunto unitário que traz consigo um sistema normativo no qual determinados valores devem receber tratamento diferenciado. Assim acontece com relação à dignidade 
humana, pois se trata de um valor supremo e fundamental, capaz de conferir uma feição particular à ordem constitucional e conteúdo axiológico ao sistema jurídico.

Ingo Sarlet (2007) define a dignidade da pessoa humana como uma qualidade inerente e diferenciadora dos seres humanos, a razão pela qual o indivíduo se torna merecedor de respeito e consideração da comunidade em que está inserido e do Estado. Essa condição especial tem como consequência o surgimento de um complexo de direitos fundamentais, decorrentes de suas necessidades básicas e seus deveres, capaz de tutelar o indivíduo contra condutas degradantes, tratamentos e situações desumanas, garantindo-lhe as necessidades mínimas para uma vida saudável.

Barroso (2003) conceitua a dignidade da pessoa humana como um conjunto de valores que auxiliam no processo de civilização e humanização. A dignidade tem seu conteúdo jurídico conectado aos direitos fundamentais e caracterizado por elementos individuais, políticos e sociais. Seu componente essencial é representado pelo mínimo existencial, correspondente às necessidades elementares, em referência às condições de subsistência física e material indispensáveis ao exercício da liberdade e da vida, distinta da mera sobrevivência.

Flávia Piovesan (2003) salienta que a dignidade da pessoa humana é um valor que constitui o elemento nuclear básico do ordenamento jurídico e auxilia na hermenêutica constitucional. Pode ser considerado um superprincípio constitucional, uma regra anterior e superior ao próprio ordenamento contemporâneo, proporcionando-lhe um sentido especial, unitário e racional.

A dignidade da pessoa humana pode ser considerada o auge axiológico da Constituição Federal, que é o âmago da tutela jurídica, o que demonstra a importância da efetividade desse princípio (Alvarenga, 2012).

Sem essas garantias, a pessoa perderia a condição de ser humano e se tornaria um animal como outro qualquer, à mercê da natureza. Por possuí-las, torna-se responsável pela promoção da participação 
ativa nos destinos da existência humana e da vida com os demais seres humanos com os quais se relaciona, sendo ainda corresponsável por essa participação e pela promoção social.

Nas lições de Kant, quando se analisam as finalidades, qualquer atuação apresenta um custo, mas também uma dignidade. Se alguma coisa tem um valor, pode ser substituída por qualquer outra coisa que apresente um valor similar. Todavia, quando uma coisa é valorada em parâmetros superiores a todas as outras que lhe são semelhantes, acima de qualquer preço, não existe a possibilidade de encontrar um equivalente para ela. Nessa situação, é possível afirmar que possui dignidade. É isso que ocorre quando o objeto de análise é o direito à vida, à integridade física e psíquica, à honra, à privacidade e a tantos outros direitos considerados essenciais. $\mathrm{Na}$ ausência de reconhecimento desses direitos mínimos, não há a concretização da dignidade humana. Eles são tão importantes que não é permitido ao indivíduo dispor deles. Se isso acontece, a consequência lógica é a redução de sua condição humana (Kant, 1986).

A dignidade humana percorre integralmente o ordenamento jurídico e impõe à hermenêutica critérios de valoração. É considerada prioridade absoluta em relação aos demais valores, ainda que necessite de ponderação, pois não há valor absoluto. Sempre são possíveis limitações quando um valor fundamental se contrapõe a outro valor também fundamental de ordem constitucional (Mendes, 2010).

O respeito à dignidade humana, posto na Constituição Federal (Brasil, 1988) como um dos fundamentos do Estado democrático de direito, é o âmago de todo o ordenamento jurídico pátrio.

O ser humano deve ser plenamente respeitado enquanto pessoa, assim como sua personalidade e sua dignidade. Seu valor é superior a qualquer outra garantia, mesmo constitucional, como o direito à pesquisa científica ou tecnológica.

Esse é o motivo pelo qual a bioética e o biodireito combatem condutas conflitantes com essa garantia. Se permitido, talvez o homem fosse reduzido à condição de coisa, o que é inadmissível, pois isso seria a negação da sua dignidade e da sua personalidade. 
Também não se devem proibir totalmente as pesquisas. A estagnação tecnológica e do conhecimento geraria consequências maléficas. O que é preciso é equilibrar e normatizar os estudos e as pesquisas feitos no tempo presente e futuros, para evitar o desrespeito à condição humana. $\mathrm{O}$ que se combate é o avanço a todo e qualquer custo, sem um estudo prévio de suas consequências.

A dignidade não é apenas um valor moral, mas também espiritual, inerente aos seres humanos. Sua manifestação está presente sobretudo em sua autonomia, na autodeterminação consciente e responsável no dia a dia, como imposição da vida. Todas as pessoas devem respeitar esses valores, tidos como superiores, que constituem as condições mínimas que o sistema jurídico deve assegurar.

Esses valores superiores, essenciais, são portanto invioláveis. Caso surja a necessidade de alguma limitação ao exercício de direitos fundamentais, deve ser feita só em caso excepcional, preservando o respeito a que todo indivíduo tem direito em razão de sua condição de ser humano (Moraes, 1998).

A dignidade humana constitui o maior valor do ordenamento jurídico. Por essa razão, atrai para si o conteúdo dos demais direitos fundamentais, inclusive o direito à vida. Esse princípio foi criado para ser "[...] referência constitucional unificadora de todos os demais direitos fundamentais" (Canotilho; Moreira, apud Silva, 2003). Ao conceituar a dignidade da pessoa humana, deve-se intensificar a valoração normativo-constitucional. Não basta limitá-la à defesa de direitos pessoais, pois ela é muito mais ampla, abarcando também direitos metaindividuais, como os direitos sociais.

A dignidade humana é a verdadeira garantia das condições mínimas de existência humana. É o direito do ser humano de ser tratado como tal, e não como um bem qualquer, como uma coisa. É o reconhecimento da proteção superior da vida humana sobre todas as demais.

Desse modo, mais do que uma dotação natural ou mesmo um valor, a dignidade da pessoa humana deriva de uma formação e desenvolvimento pessoal que tiveram êxito (Schotsmans, 2002). 


\section{Breves comentários sobre direitos da personalidade}

Os direitos da personalidade podem ser considerados cláusulas gerais de proteção à pessoa. Não se preocupam em descrever condutas, mas em estabelecer diretrizes, valores e parâmetros para interpretação (Tepedino, 2002). O intérprete terá discricionariedade quanto à interpretação, que será mais ampla quanto maior for a imprecisão conceitual da norma a ser interpretada (Cappelleti, 1993). A proteção à pessoa está alicerçada em três princípios constitucionais fundamentais: dignidade da pessoa humana, solidariedade social e isonomia, ou igualdade em sentido amplo (Tartuce, 2005).

O direito da personalidade não tem por objeto o sujeito que é seu titular, ou mesmo a coletividade que integra o polo passivo de uma obrigação passiva erga omnes, mas os bens que, em razão da valoração de seus atributos e de suas qualidades, que podem ser físicas ou morais, o tornam merecedor de individualização e proteção especial (Tobeñas, 1952).

A pessoa merece receber prioridade de tutela, porque possui o bem mais valioso e razão principal de proteção do ordenamento jurídico. Sua posição é basilar. Está exposta a inúmeras situações existenciais, que necessitam constantemente de guarida, em especial no caso de situações novas e inesperadas (Perlingeri, 1997).

Os direitos da personalidade têm por escopo proteger a pessoa, em relação a qualquer outro bem material ou imaterial, ou servir como tutela de conflitos de valores.

São direitos que se confundem com a pessoa que os possui, com o direito ao corpo, à privacidade, à imagem, entre outros (Nunes, 2011). O corpo, embora externo, compõe o sujeito e suas particularidades, portando integra a sua personalidade (Ferraz Jr., 1997).

Há um vínculo estreito entre os direitos da personalidade, os direitos humanos e os direitos fundamentais, embora não sejam sinônimos. Atribui-se a origem dos direitos associados à personalidade 
ao início do constitucionalismo, com a promulgação das primeiras constituições no século XIII (Amaral, 2002).

Os direitos da personalidade foram pela primeira vez positivados, de modo específico, pela Lei Romena, no ano de 1895 (França, 1968), pelo Código alemão em 1900 (Mallet, 2003) e pelo Código Civil suíço em 1907 (Fonseca, 2006), todos com a preocupação de tutelar o nome. O Código Civil italiano de 1942 (Cupis, 1961) ampliou a abrangência normativa dos direitos da personalidade, passando a tutelar o direito ao nome, ao pseudônimo, ao próprio corpo e à imagem.

A Declaração Universal dos Direitos Humanos, aprovada em 1948, foi outro documento essencial para a sistematização dos direitos da personalidade, pois consagrou direitos fundamentais, como o direito à vida, à saúde e ao bem-estar, à igualdade, liberdade, honra, justiça, propriedade, liberdade de manifestação de pensamento, liberdade religiosa, propriedade, ao sigilo, asilo, desenvolvimento da personalidade, entre tantos outros que não foram expressamente definidos (Nunes, 2011).

Nem todos os direitos apresentados na declaração, embora sejam fundamentais, são direitos da personalidade. Alguns têm conteúdo patrimonial, como é o caso da propriedade, mas a maioria dos direitos fundamentais também são direitos da personalidade, como o direito à vida, à saúde e ao bem-estar, à honra, à liberdade religiosa e demais direitos inerentes à condição humana.

O respeito à dignidade da pessoa humana é condição basilar para os direitos da personalidade. Ascensão (2006) esclarece que as feições da dignidade são a essência dos direitos da personalidade.

Alguns direitos da personalidade apresentam características de direito público, como os direitos da liberdade civil. Outros têm características de direito privado, porque satisfazem interesses diretos dos sujeitos, como o direito à vida, honra, liberdade e integridade física (Cupis, 1961).

O Código Civil brasileiro também dedicou atenção especial aos direitos da personalidade, atribuindo onze artigos à tutela da personalidade. 
O diploma civil afirma, inicialmente, que os direitos da personalidade são intransmissíveis e irrenunciáveis. ${ }^{1}$ Eles não podem ser afastados exclusivamente por atos da vontade (Tartuce, 2005), mas podem ser relativizados, conforme estabelece o enunciado n. 4 da Jornada de Direito Civil, promovida pelo Centro de Estudos Judiciários do Conselho da Justiça Federal. ${ }^{2}$

O direito à integridade física é garantia de proteção à vida humana. Uma conduta pode atingir diretamente a unidade biológica que compõe uma pessoa, ou atacar os aspectos que orbitam a unidade biológica, visto que ela é um ser biopsicossocial (Cordeiro, 2007).

O Código Civil resolveu tutelar, além da integridade física, o direito do paciente, visto como um dos direitos da personalidade, ao estabelecer que ninguém deve ser constrangido a submeter-se, com risco de vida, a procedimento médico-hospitalar. ${ }^{3}$

É evidente o interesse do legislador em respeitar a liberdade e a autonomia do paciente, reconhecendo-as como direitos da personalidade. Para Carlos Alberto da Mota Pinto (2005), a liberdade é manifestação da identidade, o reconhecimento de que um indivíduo é um ser humano.

A pessoa é responsável por si mesma, goza de liberdade e vontade. Por meio da autodeterminação, conduz a própria vida, elegendo os valores que lhe são mais caros e que irão nortear suas condutas e sua escolhas, segundo uma escala de valores pessoal. Suas opções são determinantes para a configuração da personalidade, que deve estar em harmonia com os valores sociais e jurídicos (Sousa, 1995).

A integridade psíquica pode ser considerada o valor mais abrangente da personalidade. $\mathrm{O}$ indivíduo não pode dispor de nenhuma

1 Brasil. Lei n. 10.406, de 10 de janeiro de 2002. "Art. 11 - Com exceção dos casos previstos em lei, os direitos da personalidade são intransmissíveis e irrenunciáveis, não podendo o seu exercício sofrer limitação voluntária."

2 Enunciado n. 4 da Jornada de Direito Civil, promovida pelo Centro de Estudos Judiciários do Conselho da Justiça Federal: "O exercício dos direitos da personalidade pode sofrer limitação voluntária, desde que não seja permanente nem geral."

3 Lei n. 10.406. "Art. 15 - Ninguém pode ser constrangido a submeter-se, com risco de vida, a tratamento médico ou a intervenção cirúrgica." 
delas, salvo quando a ponderação de valores e motivos de saúde, associados aos seus interesses, levem a conclusão contrária, permitindo sua relativização, por meio de manifestação livre e consentida, com o fim único de tutelar os seus interesses (Perlingieri, 1997).

Assim, o consentimento, que é manifestação autônoma da vontade, está vinculado aos direitos da personalidade, sendo lícita sua relativização desde que sejam obedecidas as imposições referentes à ponderação de valores (Nunes, 2004).

Essa é a razão pela qual o ordenamento jurídico permite a prática de intervenções médicas em pacientes. Tal prática macula a sua integridade física e, algumas vezes, a sua integridade psíquica, todavia a submissão de uma pessoa à obstinação terapêutica constitui uma afronta aos direitos da personalidade.

Não é sem propósito afirmar que a recusa a práticas médicas fúteis seja um meio de assegurar o respeito à dignidade da humana, que é o princípio cardeal dos direitos da personalidade.

\section{Deliberação moral}

Entende-se por deliberação de conflitos éticos a ponderação entre valores e deveres presentes no fato concreto. Seu objetivo é dirimir o conflito moral, por meio da dialética entre os envolvidos, alcançando uma solução ponderada e prudente. Para tanto, não se pretende uma solução ideal, mas razoável, distanciada da visão idealista ou utilitarista, mas sim crítica (Zoboli, 2013).

A deliberação não é afeita à abstração. Faz a análise do problema prático, valora com prudência as condutas, mas não trata os conflitos éticos como dilemas, a serem analisados em termos estatísticos, verificando matematicamente os prós e contras de cada argumento (Gracia, 2001).

Os profissionais devem estabelecer diálogos interpessoais, para que ocorra o aperfeiçoamento do pensamento e seja obtida uma decisão. As diferentes realidades colocadas à prova auxiliam no apri- 
moramento moral, pois o choque entre as diversas experiências de cada envolvido possibilita uma conduta mais ampla (Pose, 2009).

Ocorre um problema ético quando dois valores morais entram em conflito, quando dois deveres colidem, e o profissional precisa encontrar uma solução para a situação, porém nem sempre é possível saber qual a solução mais adequada (Zoboli, 2013).

Soluções morais são uma maneira de dirimir problemas éticos, porém a resposta não é única. Existem diversas possibilidades de solução, de teores variados, algumas mais radicais, outras menos. Com exceção das soluções extremas, todas as outras são consideradas prudentes, portanto adequadas sob o prisma da deliberação (Pose, 2009).

A deliberação é o caminho mais sensato quando o profissional da saúde vê-se diante de um conflito e não é possível encontrar respostas teóricas para o problema ético prático que enfrenta. Nessa situação, a deliberação auxilia na busca de uma solução que, mesmo que não seja ideal, será prudente e ponderada e, por isso, adequada (Zoboli, 2013).

Esse procedimento pode ser utilizado com sucesso tanto no momento de comunicar uma terapia a um paciente, de informar sobre um procedimento ou uma terapia médico-hospitalar, bem como na tomada de decisão, em relação ao enfermo, independente de ele aceitar ou recusar o tratamento, em relação ao médico, de modo a respeitar a autodeterminação do paciente e adotar práticas alternativas, permeadas de valores éticos e morais.

\section{Evolução histórica da bioética e da tutela da autonomia do paciente}

A bioética tem sua origem muito ligada aos direitos dos pacientes e dos sujeitos de pesquisas, os quais, por muito tempo, foram expostos a práticas lesivas, degradantes e prejudiciais, sem que houvesse qualquer preocupação com a sua proteção ou a garantia 
de receberem informações a respeito das práticas biomédicas a que eram submetidos.

Apesar dessa prática, a preocupação em resguardar os direitos fundamentais dos pacientes não é recente. Entre eles, destaca-se o direito à informação sobre os riscos a que se expõe e sobre os possíveis benefícios para só assim aceitar ou recusar um procedimento médico-hospitalar. Mais do que esclarecer o sujeito, é necessário que ele manifeste, de modo livre e voluntário, sua concordância, aceitando submeter-se a uma prática médica.

Alguns dos episódios mais atrozes da história recente da humanidade ocorreram entre os anos de 1939 e 1945, durante a Segunda Guerra Mundial. Nesse período, os prisioneiros de guerra foram recolhidos em campos de concentração e submetidos a experiências desumanas, permeadas por sofrimento, angústia, dor, que provocaram problemas mentais e físicos e, na maioria das vezes, morte, em uma verdadeira afronta aos direitos fundamentais.

Com o término da guerra e a comoção internacional, foi criado um Tribunal Militar Internacional, sediado em Nuremberg, para apurar e julgar os crimes contra a humanidade perpetrados no decorrer do evento bélico, e foi promulgado o Código de Nuremberg. Este diploma também continha diretivas internacionais sobre a ética em pesquisa, pois alguns médicos norte-americanos que participaram da Segunda Guerra Mundial também ajudaram a elaborá-lo, com o fim de auxiliar nos julgamentos dos crimes contra a humanidade pelo Tribunal Militar Internacional de Nuremberg.

Alguns direitos do paciente reconhecidos atualmente, tais como autonomia, consentimento livre e esclarecido, constavam no diploma. Contudo, os procedimentos éticos expressos no código não foram obedecidos de imediato, pois os profissionais da saúde acreditavam que as disposições nele contidas se referiam exclusivamente aos crimes de guerra.

Contagiada pelos ideais éticos, em 1948 surgiu a Declaração de Genebra, que enumerava os deveres éticos do médico quando seres humanos fossem expostos a experimentação. Contudo, o consenti- 
mento esclarecido do paciente era facultado aos casos em que fosse possível obtê-lo.

Foi no final da década de 1940 que a humanidade despertou para a necessidade de estabelecer limites éticos à ciência. No mês de dezembro de 1948, a Organização das Nações Unidas, ainda preocupada com os malefícios causados aos cidadãos pela guerra, elaborou um documento, a Declaração Universal dos Direitos $\mathrm{Hu}$ manos, cujo escopo era preservar os direitos humanos, portanto, direitos fundamentais do indivíduo, independentemente de gênero, etnia ou origem geográfica. Esse documento tem grande repercussão até os dias atuais, pois reafirmou a supremacia da defesa da autonomia do paciente como direito inerente à condição humana.

Na década seguinte, a expressão "informed consent" (consentimento informado) foi empregada pela primeira vez nos Estados Unidos. No início, foi utilizada nas pesquisas biomédicas, posteriormente passou a ser usada também no contexto da atuação médica.

Em 1964, a cidade de Helsinque, Finlândia, sediou um importante evento promovido pela Associação Médica Mundial, no qual foram amplamente discutidas as diretrizes éticas internacionais para pesquisas biomédicas envolvendo seres humanos. A denominada Declaração de Helsinque foi decisiva, ao reconhecer que o consentimento do paciente é fator preponderante na escolha da conduta a ser adotada e dos procedimentos a serem realizados. Ao longo dos anos, esse documento sofreu seis revisões, a mais recente em evento sediado na cidade sul-coreana de Seul, no ano de 2008.

Com o fortalecimento da autonomia do paciente, passou-se a analisar a autodeterminação do indivíduo, que consiste na sua adesão ou recusa antecipada a determinados tratamentos. Essa ideia surgiu nos Estados Unidos, no ano de 1967, quando a Sociedade Humana para Eutanásia discutiu a possibilidade de um termo de consentimento prévio, denominado "living will" (testamento vital). Nesse documento são enumeradas as condutas a que o paciente aceita submeter-se futuramente, caso seja acometido por uma enfermidade terminal e incurável, irreversível, que o impossibilite de 
manifestar sua vontade. Surgiam assim as diretivas antecipadas de vontade.

Louis Kutner, advogado e ativista dos direitos humanos, no ano de 1969 propôs que se adotasse um documento que possibilitasse ao paciente expressar sua vontade na hipótese de, no futuro, padecer de alguma enfermidade que reduzisse a sua capacidade de manifestação da vontade, encontrando-se em estado vegetativo, sem a possibilidade de reversão de seu quadro clínico e a retomada da sua capacidade física e mental, caso em que se estabeleceria quais tratamentos médicos seriam mantidos e quais seriam suspensos (Ribeiro, 2005). Recomendou que o documento fosse utilizado como instrumento processual de defesa, diferenciando o homicídio privilegiado, baseado na compaixão, considerado um valor moral relevante, e o homicídio qualificado, considerado motivo torpe.

Esse documento, além de possibilitar ao seu subscritor o direito à autonomia e à autodeterminação, escolhendo o momento de sua morte, permite que manifeste previamente o seu desejo de não mais viver ao encontrar-se na situação mencionada, de modo a assegurar que sua vontade seria cumprida.

Posteriormente, no ano de 1973, foi redigida a Carta de Direitos do Paciente pela Associação Americana dos Hospitais. Esse documento impunha a essas instituições de saúde, bem como a outras, que reconhecessem os direitos dos pacientes e, principalmente, informassem a eles os direitos dos quais eram titulares.

Ainda na década de 1970, a Comissão Nacional para a Proteção de Sujeitos Humanos em Pesquisas Biomédicas e Comportamentais dos Estados Unidos começou a elaborar o Belmont Report, que começou a valer em 12 de julho de 1974, estendendo-se até 1978, com sua divulgação. Esse documento possibilitou a consolidação acadêmica da bioética, assegurou ao paciente o poder de autodeterminação, de decisão em relação aos procedimentos a que aceitaria submeter-se. Nele estão elencados princípios éticos fundamentais e diretrizes que auxiliam a dirimir problemas éticos referentes à realização de pesquisas com seres humanos, além dos princípios da autonomia, da justiça e da beneficência. 
Os Estados Unidos, que possuem um sistema legal próprio, permitem a cada estado editar suas próprias leis, que coexistem com as leis federais, aplicadas a todos os estados da federação. O estado da Califórnia, em 1976, elaborou uma lei versando sobre a morte natural, a Natural Death Act, com vigência até 1991, ano em que a lei federal de autodeterminação do paciente, Patient Self Determination Act, foi promulgada e a substituiu. Essa lei federal de autodeterminação do paciente constitui um dos principais marcos legislativos para o reconhecimento e a regulamentação das diretivas antecipadas de vontade. Sua positivação repercutiu nos meios acadêmicos, fazendo surgir a necessidade de uma criteriosa análise bioética acerca do instituto.

Na Europa, a Holanda se mostrou vanguardista, ao elaborar a Declaração sobre a Promoção dos Direitos do Paciente, no ano de 1994. Esse documento reconheceu, entre outros direitos fundamentais, aqueles que se referem ao consentimento da prática de certos procedimentos médico-hospitalares, à informação e ao esclarecimento prévios ao sujeito sobre a prática que está sendo apresentada.

No ano de 1997, foi redigida a Carta de Oviedo, em evento realizado na cidade espanhola de mesmo nome. Também conhecido como Convênio sobre Direitos Humanos e Biomedicina, mais uma vez mostrou-se evidente a imperiosidade de garantir ao usuário dos serviços médico-hospitalares o direito de aceitar ou recusar, de consentir, de modo livre, espontâneo e esclarecido, um tratamento ou procedimento médico-hospitalar.

O estado de São Paulo foi pioneiro no Brasil, ao promulgar uma norma que reconhece e regulamenta os direitos de usuários dos serviços de saúde. Ela recebeu o nome de Lei Covas (São Paulo, 1999), em homenagem ao governador acometido por uma neoplasia. O documento confere ao sujeito o direito de consentir ou recusar procedimentos de modo livre, voluntário e esclarecido, após receber informações adequadas e ser esclarecido sobre os seus riscos e benefícios. 
No ano de 2002, a Espanha promulgou a Lei 41/2002 (España, 2002), que legalizou e regulamentou, naquele país, as diretivas antecipadas de vontade do paciente, denominadas "instrucciones prévias" ou "voluntades anticipadas". A mesma lei reconhece a necessidade de o paciente aceitar os procedimentos que ofereçam risco potencial, manifestando sua concordância de modo livre, esclarecido e voluntário.

A Carta Europeia de Direitos dos Pacientes, outro importante documento, foi elaborada também no ano de 2002, na capital italiana, que sediou o evento, e, como a Declaração de Amsterdam, reconheceu vários direitos fundamentais aos pacientes, em especial aqueles referentes ao seu consentimento, ao seu acesso à informação, ao seu esclarecimento, à livre escolha do profissional da saúde que auxiliará no tratamento, e concernentes ao procedimento a ser adotado, que não deverá expor o paciente a riscos desnecessários, nem a angústias, dores ou sofrimentos inúteis provocados pela prática médico-hospitalar.

A Unesco, no ano de 2005, divulgou o documento que recebeu o nome de Declaração Universal sobre Bioética e Direitos Humanos, que tem como um de seus objetivos destacar a importância da dignidade da pessoa, da vida humana e das liberdades fundamentais, promovendo-as e protegendo-as (Pessini, 2005).

O Ministério da Saúde do Brasil, no ano de 2009, editou a Portaria n. 1.820/2009, instrumento que reconhece o direito do paciente de receber informação sobre o tratamento ao qual será submetido. Somente após devidamente esclarecido ele poderá aderir ou recusar, livre e voluntariamente, a terapia proposta.

No mesmo ano, o Conselho Federal de Medicina editou a Resolução n. 1.931/2009, que deu origem ao Código de Ética Médica. Esse importante diploma, que estabelece as diretrizes éticas da profissão, considera infração a prática da distanásia (prorrogação do sofrimento do paciente terminal), bem como da eutanásia (antecipação da morte). Aconselha que se pratique a ortotanásia, oferecendo ao paciente todos os procedimentos paliativos disponíveis, capazes de aliviar seu sofrimento. 
O Uruguai, ainda em 2009, foi outro país que legalizou as "voluntades anticipadas" (diretivas antecipadas de vontade), por meio da Lei n. 18.473/2009, como já haviam feito outros países, como Grã-Bretanha, Portugal, Alemanha, Holanda, França, Espanha, Bélgica e Estados Unidos. As "instrucciones previas" (testamento vital), denominação que o instituto recebeu no país latino-americano, reconhecem ao paciente o direito de recusar ou aceitar a terapia proposta pela equipe de saúde à qual poderá ser submetido no futuro caso venha a contrair uma doença, esteja em estágio terminal, inconsciente e, portanto, impedido de manifestar sua vontade.

No Brasil, houve uma tentativa de regulamentação do tema, também no ano de 2009, quando o senador Gerson Camata apresentou o Projeto de Lei n. 524/2009.

O Conselho Federal de Medicina, em meados de 2012, por meio da Resolução n. 1.995/2012, regulamentou, segundo sua competência, as diretivas antecipadas de vontade do paciente, reconheceu sua existência e sua importância, ao descrever seu conteúdo e seu alcance, contudo ainda não existe no país, até a presente data, qualquer legislação que as regulamente. 


\section{2 \\ CONCEPÇÕES TEÓRICAS SOBRE \\ A TERMINALIDADE DA VIDA}

\section{A vida humana e sua preservação}

A vida e suas variadas formas sempre foram objeto de interesse do ser humano, seja no âmbito biológico, filosófico ou religioso. $\mathrm{O}$ maior interesse volta-se para a vida humana.

Os gregos faziam distinção entre o que se referia à vida humana e à de outros organismos vivos por meio dos radicais bio, relativo à vida humana, e zoé, concernente aos demais organismos vivos. Em latim, tem-se o termo vita, referente a todo tipo de vida, inclusive a humana (Schramm, 2009).

O que difere os seres vivos dos seres não vivos, segundo a filosofia, é que os seres vivos são capazes de realizar ações que permitem aperfeiçoar a si próprios, assim como aos demais. Sendo assim, a vida pode ser considerada a capacidade de ação imanente. O pretexto e o objetivo da ação é a pessoa (Sgreccia, 2009).

Inicialmente, essa ação estava voltada exclusivamente para as necessidades essenciais do ser vivo, ou seja, a nutrição, para obtenção de energia suficiente para a manutenção das sua atividades bioquímicas, para o seu crescimento, o seu desenvolvimento próprio, e a reprodução para a perpetuação da espécie. Posteriormente, com a 
evolução natural das espécies, desenvolveu-se a atividade sensorial, que possibilitou a autorregulação, e a capacidade intelectual e espiritual, originando-se a consciência e a liberdade (Sgreccia, 2009).

A vida humana é composta por elementos materiais (físicos e psíquicos) e imateriais (metafísicos). O conjunto desses elementos é tutelado como direito fundamental individual. É o direito de viver, defender a vida, continuar vivo. A vida não deve ser interrompida por agentes externos ao seu próprio curso (Silva, 2003).

$\mathrm{O}$ direito à vida é essencial. Não existe nenhum outro bem jurídico se não há vida (Vasconcelos, 2006).

A vida apresenta o componente biológico, que diz respeito a todas as reações físico-químicas que ocorrem no organismo; o componente psicológico, referente à condição emocional, preponderante para o bem-estar do ser humano; e o componente social, concernente às relações interpessoais, sendo que não existe vida humana isolada, pois todas as pessoas dependem das relações sociais, em maior ou menor grau. Por isso se diz que o ser humano é um ser biopsicossocial. O equilíbrio humano depende da harmonia desses três componentes. Quando um deles é abalado, o indivíduo fica fragilizado (Almeida, 2012).

Viver não é a mesma coisa que estar vivo. Viver engloba o conjunto dos elementos que compõem o ser humano, enquanto estar vivo remete apenas ao elemento biológico (Almeida, 2012).

Assim, uma pessoa pode estar viva em razão de suporte de vida artificial permanente, embora já tenha deixado de viver há algum tempo, pelo distanciamento dos elementos psicológicos e sociais, que não serão mais retomados, em virtude da irreversibilidade de seu quadro clínico. A manutenção do suporte artificial se justifica apenas pelo desejo daqueles que lhe têm afeto.

Nesse contexto, mostra-se imperioso refletir a respeito da obrigatoriedade da vida. A vida seria uma faculdade ou um dever?

É comum usar-se os termos "inviolabilidade" e "indisponibilidade" como sinônimos, mas há diferenças de significado entre eles. Inviolabilidade significa a oposição a uma agressão ou ameaça 
de agressão praticada por terceiros, enquanto indisponibilidade se refere à proibição de o próprio detentor de um bem dispor dele, protegendo-o dele mesmo. Na interpretação constitucional, a vida é um bem inviolável, porém disponível (Almeida, 2012). Não há como negar a disponibilidade da vida, a própria Constituição assim dispõe. Embora se reconheça que a vida é um bem supremo e o direito natural proíba o ser humano de renunciar à própria vida, a Magna Carta prevê a privação da vida (Ligiera, 2009).

A Constituição Federal (Brasil, 1988) assevera que não pode haver privação da vida humana e reconhece sua inviolabilidade no inciso X do art. 5ㅇ. Contudo, a alínea $a$ do inciso XLVII do mesmo artigo relativiza essa inviolabilidade, ao autorizar a pena de morte a militares, na hipótese de guerra externa.

A disponibilidade da vida também está presente na legislação infraconstitucional. O Código Penal (Brasil, 1940) não elenca a tentativa de suicídio entre os tipos penais constantes no art. 122; menciona apenas as condutas praticadas por terceiros (induzimento, instigação ou auxílio ao suicídio) como crime, reafirmando o caráter inviolável da vida.

Pode-se concluir que não existe o dever de viver, pois há previsão constitucional relativa à inviolabilidade da vida, mas não à sua indisponibilidade (Ligiera, 2009).

Assim, é possível afirmar que a inviolabilidade da vida é relativa, enquanto a disponibilidade é absoluta (Almeida, 2012).

\section{A solução jurídica para conflitos aparentes entre princípios e regras}

O direito se expressa por meio de princípios e regras (Dworkin, 2013), os quais constituem normas, pois são formulados por meio de expressões impositivas que determinam deveres, permissões e proibições, fundamentando ponderações concretas de dever-ser. A distinção entre princípios e regras repousa no seu conteúdo qualitativo (Alexy, 2008). Os princípios jurídicos podem ser tratados 
como regras jurídicas. Alguns têm a mesma obrigatoriedade que a lei, e devem ser assim considerados por toda a comunidade jurídica. Constituem comandos que podem ser satisfeitos em graus variados, o que não resulta apenas das realidades fáticas, mas também das possibilidades jurídicas, que surgem pelo conflito de princípios e regras.

As regras são normas que podem ser satisfeitas ou não. A validade de uma regra impõe que seja feito exatamente o que ela exige, sem extrapolações. Regras se referem a determinações fáticas e juridicamente possíveis.

O conflito entre regras é resolvido por meio de critérios como anterioridade (cronológico) - lex posterior derogat priori (a lei posterior revoga a anterior); hierarquia - lex superior derogat inferiori (a lei superior revoga a inferior); e especialização - lex specialis derogat generali (a lei especial revoga a lei geral) (Bobbio, 2008).

No conflito de regras, apenas uma delas pode ser válida, e cabe ao intérprete a função de decidir qual é válida e qual necessita de reformulação ou não deve ser levada em conta. É tarefa do sistema jurídico regular esses conflitos por meio de regra de precedência, regra mais específica ou pela hierarquia. $\mathrm{O}$ sistema jurídico pode ainda determinar a prevalência da regra, com base em princípios de importância superior (Dworkin, 2013).

Quando há colisão de princípios, isso significa que um deles tem precedência em relação ao outro. É a denominada relação de precedência condicionada, em que, no caso concreto, um dos princípios deve ser valorado mais intensamente em relação ao outro, em virtude de interesses colidentes, embora todos os princípios, como valores abstratos, se encontrem no mesmo nível (Alexy, 2008).

É fundamental destacar que a proporcionalidade é um instrumento metodológico importante para a promoção da justiça na ordem jurídica. É um mecanismo que desperta no ordenamento jurídico um valor de justiça que lhe é inerente, garantindo à população a tutela adequada, por meio de um sopesamento entre bens jurídicos, que podem ser valorados de modo distinto, bem como pela 
relativização de direitos fundamentais, quando estes se encontram em conflito (Soares, 2008).

A proporcionalidade abarca três axiomas parciais: adequação, ou idoneidade, necessidade e proporcionalidade, em sentido estrito. A adequação e necessidade têm origem na natureza dos princípios, perante as possibilidades que o caso concreto oferece, enquanto a proporcionalidade, em sentido estrito, decorre das possibilidades jurídicas (Alexy, 2008).

A ponderação apresenta um caráter formal, logo não pode ser considerada objetiva, porque haverá um subjetivismo em sua apreciação, mas também não é correto afirmar que esteja apenas baseada nele. Não há objetividade perfeita em nenhum campo normativo, pois não existe sistema jurídico ideal, que estabeleça com exatidão todas as condutas permitidas ou proibidas. Além disso, os princípios são sempre disposições hipotéticas indeterminadas, portanto é impossível prever e regular todos os conflitos que poderão emergir (Pulido, 2008).

É impossível encontrar um sistema dotado de tamanha racionalidade, que consiga excluir por completo qualquer subjetivismo presente na interpretação ou na aplicação da norma (Silva, 2009).

A solução de conflitos aparentes sempre deverá considerar as regras de hermenêutica jurídica, bem como a ponderação do intérprete, que desempenha função fundamental, em razão do subjetivismo que é próprio da tarefa interpretativa.

\section{O paradigma biotecnocientífico e sua influência no conceito de vida}

O paradigma biotecnocientífico ${ }^{1}$ consiste nas ferramentas técnicas e teóricas, institucionais e industriais que permitem estudar,

1 Biotecnociência é o “[...] conjunto de ferramentas teóricas, técnicas, industriais e institucionais que visam entender e transformar seres e processos vivos, de acordo com necessidades e desejos de saúde [e] visando a um genérico bem-estar de indivíduos e populações humanas" (Schramm, 2005). 
modificar e transformar seres vivos e processos biológicos, conforme as suas necessidades, com o fim de promover o bem-estar das pessoas.

A evolução biotecnocientífica, que acelerou o ritmo de produção biotecnológica a partir da década de 1970, fez que a acepção do termo "vida" fosse repensada, pois práticas até então inexistentes passaram a ser utilizadas, alterando o ciclo natural (Schramm, 2005).

A intervenção humana nos processos biológicos fez que esse ciclo de vida natural fosse relativizado, deixando de ser apenas natural. O ser humano passou a agente transformador da vida, ampliando-a e ou reduzindo seu tempo.

Uma questão fundamental deve ser discutida inicialmente, pois é anterior a qualquer questão jurídica e bioética que envolva o princípio ou o término da vida: A vida possui um valor intrínseco? Este valor deve ser objeto de discussão? (Dworkin, 1998).

Ajudam a responder a essa questão dois princípios que, embora antagônicos, complementam um ao outro e, em situações limite, diante de conflitos éticos, auxiliam a encontrar a solução mais adequada: o princípio da qualidade de vida e o princípio da sacralidade da vida.

Pelo princípio da qualidade de vida, será possível a intervenção na vida humana sempre que o objetivo for promover o bem-estar do seu titular, desde que não haja prejuízos para terceiros. Em outras palavras, trata-se de uma intervenção que visa minorar o sofrimento da pessoa, melhorando sua qualidade de vida, ainda que para isso seja necessário interferir diretamente na vida (Schramm, 2009).

Pelo princípio da sacralidade da vida, esta é indisponível inclusive para o seu titular, que não pode interferir nos ciclos da natureza, ainda que seu objetivo seja a promoção do seu próprio bem-estar. Nenhuma intervenção pode ser realizada na vida, de modo independente dos seus propósitos (Schramm, 2009).

A sociedade atual é multifacetada, com uma moral plural, e não apresenta um padrão homogêneo de comportamento, o que po- 
deria levar a considerar um desses princípios principal em relação ao outro. Acredita-se que vivemos em um momento de transição. Antes preponderava a sacralidade da vida, acreditava-se que ela era um bem supremo e indisponível, contudo, na época atual, essa não é mais a visão dominante. Muitas pessoas consideram a qualidade de vida um bem superior à própria vida.

Há um verdadeiro embate de paradigmas entre a ideia de sacralidade da vida, por séculos considerada um valor absoluto, e a ideia de qualidade de vida, derivada das teorias de direitos humanos, afeita à autodeterminação e considerada um valor (Schramm, 2009).

Se o princípio da sacralidade for considerado o mais importante, a vida deverá ser mantida a todo custo, lançando-se mão de avançados procedimentos científicos, independente das consequências para a pessoa. Afinal, por esse princípio, a vida é um valor absoluto (Kovács, 2003).

Se a discussão não se restringe ao tempo de vida, mas abrange a qualidade de vida, o sofrimento impingido à pessoa e sua intensidade, pondera-se qual será a melhor solução: deixar que continue sofrendo ou vivendo (Kovács, 2003).

A sacralidade da vida deve transcender o caráter religioso teísta. A morte antecipada é interpretada como uma afronta à própria evolução natural, por essa razão a vida pode ser considerada um bem moralmente inviolável. Ademais, a vida humana constitui a reunião de inúmeros investimentos criativos, que se iniciaram desde que o indivíduo foi concebido, passaram pela sua formação e permanecem até o fim de seus dias (Junges, 1993). A abordagem quantitativa da vida, presente na sacralidade, não necessita necessariamente estar vinculada à religiosidade, ainda que a origem da vida, sob a perspectiva não religiosa, continue um grande mistério. É importante que essa abordagem seja considerada e defendida, mas não é preciso que se contraponha à abordagem qualitativa, voltada para a qualidade de vida. O que se mostra fundamental é buscar a conjugação de ambas, com o objetivo de proteger a pessoa humana, e um princípio não deve ser utilizado em contraposição ao outro, mas em união com o outro (Junges, 1993). 
Em razão dessa dicotomia, surge um terceiro princípio que pode auxiliar na busca de uma solução razoável: o princípio de indiferença da natureza, pelo qual existe distinção entre a vida biológica e a vida biográfica. A vida biológica não pode ser valorada como boa ou má; é neutra, pois se refere apenas a estar vivo, enquanto a vida biográfica pode ser valorada, com base em aspectos positivos (boa) ou negativos (má) (Mori, 2014).

Ao analisar os princípios da sacralidade e da qualidade de vida, a vida biológica e a biográfica, pode-se indagar: Qual deve receber maior valor? Qual deve preponderar?

Uma pessoa pode ser mantida viva, mesmo sem viver, apenas com o coração batendo artificialmente, inconsciente, sem nenhuma esperança de reversão do quadro médico (Kovács, 1998).

Por essa razão, temas concernentes ao término da vida humana, como a eutanásia, a distanásia, a ortotanásia, as diretivas antecipadas de vontade, são tão debatidos e geram tantas e tão diversas opiniões, todas com argumentos sólidos, para demonstrar sua convicção, auxiliando no processo biotecnocientífico.

\section{Morte digna}

O choque entre princípios, ou direitos fundamentais, pode dar origem a novos princípios, ou direitos fundamentais. $\mathrm{O}$ intérprete é responsável por harmonizar os conflitos entre normas, sem que qualquer regra seja desconsiderada (Dias, 2012).

A Constituição Federal preceitua a possibilidade de direitos fundamentais surgirem de princípios como consequência da ponderação. Surge uma nova regra ajustada ao caso concreto e com aplicabilidade imediata. A colisão de direitos fundamentais pode dar origem a um novo direito fundamental que não se confunde com aqueles dos quais se originou e aplicável ao caso concreto (Dias, 2012).

Só ocorre colisão de direitos fundamentais se um direito fundamental de um indivíduo interfere negativamente ou causa dano a um direito fundamental de outro indivíduo. Quando ambos os 
direitos fundamentais têm como titular o mesmo indivíduo, considera-se que há um falso problema (Nery Jr., 2012).

$\mathrm{O}$ direito à morte digna surge do conflito e da harmonização entre os direitos fundamentais à vida, à dignidade e à liberdade. Possui conteúdo próprio, distinto dos direitos que lhe deram origem, mas tem origem na sua harmonização, a partir da ponderação das necessidades do caso concreto.

Em alguns contextos, os médicos podem manter vivas, por longos períodos de tempo, pessoas que se encontram em situação de terminalidade, sem perspectiva de melhora ou de cura, inconscientes, sob o efeito de sedativos ministrados para amenizar seu sofrimento, irreconhecíveis em razão dos procedimentos a que são expostas, mantidas vivas por meio de tubos e aparelhos. $\mathrm{O}$ paciente se torna uma arena romana, em que os médicos digladiam contra a morte, causando angústia a todos os envolvidos. É da natureza humana temer o fim da vida, assim como a vida vegetativa, ainda que sejam oferecidos cuidados de extrema qualidade. Questiona-se o interesse e a validade desse tipo de conduta e tratamento (Dworkin, 2009).

$\mathrm{O}$ direito à dignidade não pode restringir-se ao período em que a pessoa desfruta os prazeres da vida. Deve estender-se a todas as etapas, inclusive quando os valores existenciais se modificam, em razão das diferentes necessidades especiais de cada fase da vida, respeitando-se os valores de cada indivíduo, sua vontade, sua liberdade, sua autodeterminação.

$\mathrm{O}$ direito à morte digna consiste em respeitar a autonomia do indivíduo, sua personalidade, seus valores, sua concepção de vida e morte, que nada mais é do que a etapa conclusiva do fenômeno chamado vida.

Morrer dignamente é poder escolher o modo e o momento adequado de partir, de acordo com os próprios valores, a própria personalidade. É permitir que a vida tenha continuidade, ainda que caminhe para o seu término, e receber na etapa final os mesmos cuidados das fases iniciais (Matias, 2004).

A morte coloca fim a tudo, não significa apenas o começo do nada. Devemos reconhecer a importância da dignidade humana e preservá-la em qualquer etapa da vida. Isso significa que a vida 
deve ser vivida com dignidade, e também terminar com dignidade. A morte, desse modo, seria o reflexo de todos os valores de uma pessoa ao longo dos anos em que viveu (Dworkin, 2009). A tecnologia permite manter um paciente terminal, sem perspectiva de melhora, sofrendo de dores terríveis, por períodos que vão de horas a anos. Esse procedimento realmente interessa a essa pessoa que sofre, ou estaria apenas prolongando o seu sofrimento e retirando-lhe a dignidade no desfecho de sua existência? (Souza, 2002).

A morte digna é a morte natural, em que a pessoa tem seu sofrimento aliviado por receber cuidados médicos paliativos adequados, em que ela é tratada, e não mais se combate a sua enfermidade, incurável.

Não se deve entender a morte digna como antecipação do fim da vida, pois não é isso o que acontece, mas relacioná-la à qualidade da vida, a qual não pode reduzir-se ao seu componente biológico. Morte digna significa evitar que o processo de morte seja retardado por meio da obstinação terapêutica, que realiza tratamentos fúteis, visto que a cura já não é mais possível.

Algumas vezes, o direito à vida transforma-se no dever de estar vivo. Isso penaliza o enfermo e retira-lhe o direito de libertar-se da dor, que pode ser muito intensa. A vida, deteriorada, perde o sentido, e o direito a ela passa a não ter sentido para o seu titular, condenado a um sofrimento sem prazo para terminar (Ribeiro, 2006).

A autonomia do enfermo deve ser preservada. É ele quem deve escolher quais pessoas deseja perto dele na etapa final da sua vida, quais cuidados deseja receber, como deseja ser tratado. E, mesmo que peça de modo contundente ao médico que antecipe a sua morte, este ato não caracterizaria o direito à morte digna.

Morte digna é a situação em que os tratamentos infrutíferos são suspensos, uma vez que não há possibilidade de sobrevivência e todo e qualquer esforço apenas ampliaria o sofrimento do sujeito, sem lhe trazer nenhum benefício (Pessini, 2000).

Morrer com dignidade não é apenas um direito, mas a efetivação de vários direitos: de autonomia, de consciência, de liberdade e, principalmente, de dignidade. É a busca pela morte natural, sem o 
sofrimento associado à obstinação terapêutica, que apenas prolonga a angústia dos envolvidos. É a busca do direito do ser humano de autodeterminação (Borges, 2007).

$\mathrm{O}$ direito à morte digna envolve situações de conflito entre escolhas, desejos e decisões sobre questões que envolvem a ética e a moral (Kovács, 1998).

O prolongamento de terapias sem resultado, em situações irreversíveis, consiste em uma violação à dignidade da pessoa humana, causa sofrimento e dor não apenas ao paciente, mas também aos seus familiares e a todos os profissionais envolvidos no processo, razão pela qual a prática médica deve ser ponderada e os interesses e valores devem ser harmonizados.

\section{O fim da vida em suas espécies}

Não se pode negar a finitude da vida humana. Em algum momento, a vida que habita todo ser humano será extinta. Morte e vida são as únicas certezas humanas, mas ainda existem questionamentos que ultrapassam a esfera jurídica e que implicam o auxílio de outras áreas do conhecimento, como a medicina, a filosofia e a psicologia, em uma dialética interdisciplinar (Marreiro, 2013).

A discussão sobre o fim da vida remete à preocupação de defesa da dignidade também nessa fase terminal e grande parte da discussão gira em torno dos meios para alcançar esse fim. O debate torna-se mais complexo devido a certa confusão terminológica, que, muitas vezes, não deixa explicitamente claro o que é condenado ou aprovado (Pessini, 2004). Desse modo, mostra-se imperioso proceder à distinção conceitual entre eutanásia, suicídio assistido, mistanásia, distanásia e ortotanásia, que é o que faremos a seguir.

\section{Eutanásia}

Littré (1908) define eutanásia como boa morte, morte suave e sem sofrimento. Em tempos mais recentes, entende-se eutanásia 
como uma antecipação voluntária do passamento, para dar fim a um sofrimento insuportável, imbuída de um caráter humanitário, sobretudo no que diz respeito ao enfermo, mas que se estende à coletividade à qual ele pertence (Siqueira-Batista, 2005).

Pode-se afirmar que a eutanásia é um ato médico, munido de um sentimento humanístico, que, utilizando de meios para dar fim à dor e ao sofrimento, acaba por abreviar a vida (Conselho Federal de Medicina, 1998).

Para certos autores, como Garcia (2007), o termo "eutanásia" deve ser utilizado exclusivamente para nomear as práticas de profissionais da saúde juridicamente tuteladas, aplicadas em pacientes em estágio terminal, vítimas de doenças graves, com severas limitações físicas e intenso sofrimento, as quais acabam por antecipar a sua morte. Já a conduta de um leigo fundamentada na piedade e na misericórdia deveria receber o nome de "homicídio piedoso", afinal, é o sentimento de compaixão que induz a tal prática, segundo Garcia (2007).

O Código Penal (Brasil, 1940), no parágrafo 1ํdo art. 121, chama de "homicídio privilegiado" o ato de homicídio cometido por um agente, movido por relevante valor moral ou social. Nesse caso, a pena será reduzida em até um terço.

Já o Código de Ética Médica (Conselho Federal de Medicina, 2009), no caput do art. 41, proíbe o profissional de abreviar a vida do paciente, mesmo a pedido dele ou de seus familiares, considerando tal prática uma infração ética punível.

A eutanásia recebe diferentes classificações, com destaque para aquelas que consideram o ato em si ou o consentimento do enfermo (Siqueira-Batista; Schramm, 2005).

Em relação ao ato em si, tem-se: eutanásia ativa: ato deliberado de provocar a morte sem sofrimento do paciente por fins humanitários (exemplo: injeção letal); eutanásia passiva: omissão proposital de procedimentos que garantiriam a perpetuação da sobrevida (exemplo: deixar de usar certos medicamentos); eutanásia de duplo efeito: nos casos em que a morte é acelerada em consequência de ações médicas, não visando o êxito letal, mas sim o alívio do so- 
frimento, gerando secundariamente a morte (exemplo: injeção de morfina para controle da dor, levando secundariamente a parada respiratória).

Em relação ao consentimento do enfermo, tem-se: eutanásia voluntária: vontade expressa do doente, o que seria o mesmo que suicídio assistido; eutanásia involuntária: realizada contra a vontade do enfermo, o que pode ser igualado a "homicídio"; eutanásia não voluntária: quando a vida é abreviada sem que se conheça a vontade do paciente.

O suicídio assistido é uma variável do suicídio comum. Toda morte advinda de uma ação ou da omissão do próprio agente, consciente de sua conduta, deve assim ser considerada (Durkhein, 2000).

Com a finalidade de garantir o direito a uma morte digna, há quem defenda o suicídio assistido, prática institucionalizada na Holanda e na Suíça, configurada pela aplicação de uma injeção de substância letal pelo próprio paciente, orientado ou auxiliado por terceiros ou por um médico (Diniz, 2002).

O suicídio assistido é uma prática muito criticada, porque o auxílio de um profissional da saúde a um paciente que busca a morte atenta contra os princípios da ciência médica, que, ao contrário, busca salvar, e não abreviar a vida (Sousa, 2013).

A diferença entre a eutanásia e o suicídio assistido é que neste o próprio doente provoca a sua morte, enquanto na eutanásia outra pessoa põe fim à sua vida.

A análise da conduta, contudo, pode ser distinta. $\mathrm{O}$ médico não tem como objetivo antecipar a morte, mas aliviar o sofrimento do paciente, permitir que a sua dignidade seja preservada, reconhecendo o direito que ele e todas as pessoas têm de não sofrer (Chaves, 1994).

O suicídio se tornou internacionalmente conhecido com a ampla divulgação do caso do médico norte-americano Jack Kevorkian, apelidado pela imprensa de "Dr. Morte", que inventou a Thanatron, uma máquina de suicídio composta por um aparelho de eletrocardiograma munido de um mecanismo que, ao ser acionado 
pelo próprio paciente, injeta em sua veia uma substância salina neutra que contém o anestésico Tiopental, acarretando inconsciência. Em seguida, uma dose letal de cloreto de potássio paralisa o coração. O médico disponibilizou o aparelho a 130 clientes, que o utilizaram, cometendo suicídio (Sousa, 2013).

O Michigan, estado de origem do médico, não possuía legislação que proibisse o suicídio assistido. Todavia, o médico foi denunciado, julgado e condenado por homicídio, embora tenha sido comprovado que seus pacientes eram suicidas seguros de sua decisão. Uma das pacientes deixou uma nota confessando que, conscientemente, não suportaria os sofrimentos de sua doença e não queria que sua agonia fosse presenciada pelos seus familiares. A defesa de Kevorkian sustentou que a decisão condenatória era incoerente, surgindo o seguinte dilema: por um lado, proibia-se um adulto consciente de pôr fim à sua vida com assistência médica; por outro lado, permitia-se o aborto, apesar de este colocar fim à vida da vítima sem a sua anuência (Diniz, 2002).

$\mathrm{O}$ argumento da defesa fundamentou-se na autonomia da vontade e na autodeterminação do indivíduo que não suporta mais o sofrimento causado pela enfermidade, mas está condenado a viver e suportar todas as dores enquanto a morte natural não chega, trazendo-lhe alívio e paz.

No Brasil, o suicídio assistido é inadmissível por expressa determinação do art. 122 do Código Penal, que estabelece reclusão que pode chegar a seis anos na hipótese de o suicídio ser consumado. Se a tentativa de suicídio resultar em lesão corporal de natureza grave, a sanção poderá ser de reclusão por um período de até três anos. Induzir ou auxiliar o suicídio são condutas passíveis de apenação.

No Brasil, uma denúncia envolvendo uma médica que, supostamente, acelerava a morte de pacientes na Unidade de Tratamento Intensivo do Hospital Evangélico de Curitiba ganhou grande repercussão no início do ano de 2013 (Médica acusada..., 2014).

A médica, chefe do setor de UTI de um dos maiores hospitais da capital paranaense, juntamente com outros médicos e enfermeiros, 
além de uma fisioterapeuta, que compunham a equipe de saúde, foram denunciados pelo Ministério Público paranaense e pelo Núcleo de Repressão aos Crimes contra a Saúde (Nucrisa), sob a acusação de homicídio e/ou formação de quadrilha, no período entre janeiro de 2006 e fevereiro de 2013 (Leitão, 2014).

A denúncia foi que a equipe médica, em razão da falta de leitos para acolher todos os pacientes que necessitavam de tratamento, elegia aqueles que permaneceriam na UTI e aqueles que deveriam ceder sua vaga para enfermos com maiores perspectivas de cura (Médica acusada..., 2014).

Os acusados negaram a prática de eutanásia, tipificada como homicídio, uma vez que o Código Penal não dispõe de tipo penal específico para essa conduta.

O processo ainda não chegou ao seu término, contudo houve grande manifestação popular contrária à prática da eutanásia, demonstrando que parte considerável da população brasileira opõe-se à abreviação da vida de um paciente por um médico, ainda que a conduta seja revestida por valores humanitários.

\section{Distanásia}

O ofício médico, desde o princípio do exercício da medicina, e ao longo dos séculos, sempre teve o fim maior de buscar a cura das enfermidades e diminuir o sofrimento. Porém, nem sempre a cura é possível. Como deve proceder o médico nessa situação? Lutar até o fim, independentemente dos custos para o paciente? Ou aceitar que nem sempre curar é possível?

A distanásia nada mais é do que a obstinação ou futilidade terapêutica, ou seja, a prática de buscar prolongar ao máximo o tempo da vida humana, combatendo a morte como se ela fosse o grande e último inimigo (Pessini, 2001).

O termo "distanásia" significa "morte lenta", que se prolonga no tempo e traz intenso sofrimento, provocando dores e aflições a todos os envolvidos (Lemes, 2000). 
A expressão "futilidade terapêutica" originou-se do inglês "medical futility” e é utilizada sobretudo nos países anglo-saxões. Já a expressão "obstinação terapêutica”, ou "encarniçamento terapêutico", tem origem na expressão francesa "l'acharnement thérapeutique" e é utilizada principalmente em países europeus (Villas-Bôas, 2008).

Essas expressões têm o mesmo significado e referem-se à prática da distanásia, emprego de procedimentos médico-hospitalares para buscar, inutilmente, a cura de uma enfermidade, gerando um sofrimento maior, sem promover nenhum benefício ao paciente (Pessini, 2001), além de desrespeitar a vontade dele.

O preço do avanço biotecnológico é a despersonalização da dor e da morte. Ao usar meios para prolongar a vida, promove a intensificação das dores. Além disso, não se conhece o limite para a vida mantida por meio de suporte artificial, o que, muitas vezes, gera mais perdas do que ganhos aos pacientes e seus familiares (Martin, 1993).

Na distanásia, sacrifica-se a qualidade de vida em favor do prolongamento do tempo de vida. Quando não existe mais possibilidade de cura, como no caso de pacientes terminais, o objetivo de buscá-la perde o sentido (Oliveira, 2013).

Constitui uma violação à liberdade individual expor uma pessoa a um processo lento e doloroso de morte, fazendo-a sobreviver de modo artificial, apenas pelo fato de se dispor de recursos técnicos, sem nenhuma preocupação com o ser humano, suas aflições e seus desejos. Mais do que isso, trata-se de conduta incivilizada, que afronta a dignidade da pessoa humana, pois demonstra falta de compaixão com relação ao paciente e sua família, que também tem seu sofrimento prorrogado e ampliado (Palmer, 2002).

A ideia de que a vida biológica é um bem supremo, que merece a concentração de todos os esforços disponíveis para ser mantida, independente do sacrifício da qualidade de vida, é um dos fatores que leva o profissional a praticá-la. Muitos profissionais, acostumados a salvar vidas, têm dificuldade em aceitar a morte, o que lhes traz grande angústia (Oliveira, 2013). 
Ainda, com vistas a evitar ser acusado de atuação médica equivocada e responder por isso, alguns profissionais optam por realizar procedimentos médico-hospitalares desnecessários (Pinto, 2008).

Embora aconteça com pouca frequência, alguns profissionais empregam procedimentos médico-hospitalares de alto custo, mesmo à revelia da vontade do paciente, para tentar inutilmente mantê-lo vivo, com a intenção de obter ganhos financeiros (Villas-Bôas, 2008).

O interesse econômico pode ser tanto do profissional da saúde quanto do hospital. O prejuízo se volta para o paciente, que depositou sua confiança no médico, ou para o seu plano de saúde, que suportará os altos custos do procedimentos, ou para a Administração Pública, se o tratamento for feito na rede pública de saúde.

A vaidade também leva muitos profissionais à prática da distanásia. Eles não admitem o insucesso das tentativas de tratamento e veem a morte não como uma circunstância própria da vida, mas como um fracasso pessoal. Por esta razão, lutam contra ela como se fosse um inimigo que se aproxima (Villas-Bôas, 2008).

O Código de Ética Médica determina que a distanásia seja evitada, que os doentes terminais, que padecem de moléstia incurável, recebam todos os cuidados paliativos disponíveis, que não sejam empreendidas ações diagnósticas ou terapêuticas obstinadas ou inúteis, que seja respeitada a autodeterminação do paciente.

Contudo, é imperioso ressaltar que todo procedimento deve ser discutido com o paciente ou com seus familiares, pois são diferentes as suas maneiras de ver a vida e o uso de procedimentos terapêuticos. Por meio do diálogo, a autodeterminação do paciente será respeitada, assim como será preservada a relação entre médico e paciente nessa situação limite (Scrigni, 2013).

\section{Ortotanásia}

O termo "ortotanásia" quer dizer morte correta (ortho = certo, thanatos $=$ morte). Trata-se do não prolongamento do processo 
natural de morte (Borges, 2012). Também é denominada de "paraeutanásia” ou "eutanásia por omissão" (Diniz, 2002).

Consiste em permitir que a morte ocorra no seu próprio tempo, sem adotar qualquer conduta com vistas a antecipar ou prolongar esse processo natural, seja por omissão, suspendendo suportes vitais, caracterizando um comportamento comisso, seja pela ação de retirada ou desligamento de equipamentos que funcionam como substitutos de órgãos ou que controlam suas funções, causando o colapso do organismo e desencadeando a morte. Pelo prisma da ortotanásia, a morte é algo que faz parte da vida, e procura-se fazer que o paciente em fase terminal e seus familiares enfrentem-na com certa tranquilidade. Nesse processo, há a conjugação do conhecimento ético com o componente técnico. Respeita-se a autonomia do doente e proporciona-se a ele um tratamento paliativo para diminuir sua agonia e seu sofrimento. Ele não é tratado como mero objeto, sujeito ao prolongamento ou à abreviação de sua vida de acordo com as conveniências da família ou as escolhas da equipe médica (Pessini, 2004).

A Organização Mundial da Saúde (OMS) define como cuidados paliativos aqueles que têm por objetivo melhorar a qualidade de vida dos doentes que estejam vivenciando uma doença grave ou incurável, que ameace a vida. O tratamento visa sobretudo a prevenção e a diminuição do sofrimento, mas não se restringe às dores físicas, pois é oferecido apoio para enfrentar os problemas psicossociais e espirituais (Instituto Nacional do Câncer, 2014).

O profissional da saúde não deve visar prolongar indefinidamente a vida do paciente, gerando-lhe sofrimento insuportável e desnecessário. Ao contrário, deve evitar procedimentos considerados desproporcionais, extraordinários ou fúteis, que não proporcionarão nenhuma melhora ao paciente (Nunes, 2009), a menos que este manifeste o desejo de que assim seja (Santos, 1998).

O médico deve promover a saúde e o bem-estar do paciente, e não ampliar seu mal-estar (Pessini; Barchifontaine, 2000). Por isso, iniciar uma terapêutica considerada fútil pela ciência médica, bem 
como dar continuidade a um tratamento que não proporciona nenhum benefício ao paciente, não é uma atitude profissional.

Pode-se afirmar que a ortotanásia é mais do que uma simples atitude médico-hospitalar, é um ideal pelo qual tanto o direito quanto a medicina devem lutar (Pessini, 2001).

A ortotanásia encontra-se prevista na Resolução n. 1.805/2006, do Conselho Federal de Medicina, que foi elaborada sob a influência do princípio da dignidade da pessoa humana.

A resolução permite a limitação ou suspensão de procedimentos e terapias que busquem prolongar a vida de paciente em fase terminal, porém determina que a vontade dele seja respeitada e impõe ao médico o dever de esclarecer-lhe quais são os tratamentos mais adequados para o caso dele, inclusive assegurando-lhe o direito de solicitar outra opinião médica.

Reconhece ainda o direito do paciente de continuar recebendo cuidados paliativos, que aliviam os sintomas e diminuem o sofrimento, e assegura-lhe a assistência integral, de modo a proporcionar-lhe conforto físico, psíquico, religioso e social, sendo-lhe permitido ainda o direito de alta hospitalar.

Em 2007, o Ministério Público Federal entrou com uma Ação Civil Pública (Brasil, 2012) contra a referida resolução, requerendo a sua nulidade e exigindo que os critérios para a prática da ortotanásia fossem definidos (Conselho Federal de Medicina, 2014).

A defesa apresentou parecer expondo os conceitos de eutanásia, ortotanásia e distanásia, detalhando suas aplicações e distinções, conforme solicitado, e pleiteou a improcedência da ação.

Em 2010, a Ação Civil Pública foi julgada improcedente. Tanto o juiz quanto a Procuradoria Federal entenderam que a posição do Conselho Federal de Medicina (2014) é válida.

A legislação penal silencia com relação ao tema, embora, em 1984, tenha sido proposta uma reforma do Código Penal, com a inclusão do parágrafo 4o ao art. 121, tornando a ortotanásia não punível, contudo a proposta foi rejeitada. O texto legal propunha que a ortotanásia excluísse a ilicitude do homicídio (Junges, 2010). 
Fica evidenciado que, na ortotanásia, a vida do paciente não é abreviada, nem mesmo prolongada, mas ocorre de modo natural, sem interferência humana direta. O que se objetiva é promover o bem-estar do paciente, que já se encontra fragilizado devido à doença e não deseja ter seu sofrimento prolongado e ampliado por práticas que não lhe trarão benefícios, apenas estenderão sua agonia.

Seguindo as lições da deliberação moral, a eutanásia, ou suicídio assistido, seria considerada uma prática extrema, pois anteciparia a morte do paciente por meio de conduta médica, ainda que a decisão esteja permeada por um espírito humanitário. No extremo diametralmente oposto estaria a distanásia, que, refutando o processo de morte, busca combatê-la, mesmo que o custo dessa conduta seja a ampliação desnecessária do sofrimento do doente terminal.

Nesse contexto, a ortotanásia se apresenta como solução mais ponderada, pois não antecipa a morte, nem a prolonga obstinadamente. Opta-se por tratar o paciente, quando a cura já não é mais possível, permitindo que a vida siga seu fluxo normal e buscando aliviar seu sofrimento. 


\section{3 \\ REFLEXÕES SOBRE O CONSENTIMENTO \\ LIVRE E ESCLARECIDO}

O Belmonte Report teve fundamental importância para a discussão da autonomia da vontade nas questões que envolvem a bioética. Estudos e debates não aconteceram apenas quando do surgimento do documento, mas persistem até a atualidade.

Uma das discussões que ganharam corpo com o desenvolvimento do pensamento bioético e jurídico refere-se ao consentimento do sujeito a sujeitar-se a procedimentos e pesquisas. Esse consentimento, que deve obrigatoriamente ser manifestado após esclarecimento prévio e de forma livre, é corolário do princípio da autonomia da vontade, disposto pela primeira vez no diploma norte-americano e tido como princípio basilar da bioética.

Argumenta-se que a mudança no modo como se estabelece a relação médico-paciente pode ser a responsável pelo reconhecimento desse importante direito, mas também pode-se considerar que esse princípio seja apenas um desdobramento da dignidade da pessoa humana.

A relação médico-paciente baseia-se exclusivamente na confiança. Desse modo, uma atitude inapropriada pode comprometer essa relação. Para que se mantenha adequada, é preciso fidelidade de ambas as partes. O profissional deve preservar as informações que lhe são confiadas, esclarecendo os riscos, benefícios e prognósticos concernentes ao procedimento a quem busca seus préstimos. 
O médico é escolhido pelo paciente, ou pela sua família, para auxiliá-lo na prevenção ou no tratamento de uma enfermidade. Cabe ao paciente administrar a sua saúde. Nesse contexto, a consulta e o ato médico tornam-se uma relação de sinergia (Sgreccia, 2009).

Existe uma relação assimétrica entre médico e paciente. $\mathrm{O}$ profissional da saúde dispõe do conhecimento técnico imprescindível para a restituição da saúde. Já o paciente encontra-se fragilizado física ou mentalmente, por causa da doença (Tavares, 2008). Essa relação, que por sua própria natureza já é desigual, tornou-se ainda mais distante com o avanço biotecnológico, que contribuiu para que cada vez mais os profissionais se superespecializassem. Ocorreu a desumanização do médico, que se tornou um técnico, ignorando, muitas vezes, os aspectos humanos, fundamentais na relação médico-paciente (Sampaio, 2010).

Apesar de desgastada, essa relação ainda tem importância. Muitos profissionais zelam por ela, guiados pelo Código de Ética Médica. O Código, no capítulo I, ao estabelecer os princípios fundamentais do diploma, remete aos ensinamentos de Hipócrates e "[...] defende o amor ao paciente como forma de amor pela arte médica” (Neves, 2010), orientando a atuação profissional. Esse documento reconhece também os princípios bioéticos que garantem ao paciente: autonomia, beneficência, não maleficência, justiça, cidadania, responsabilidade e dignidade humana.

A relação médico-paciente não apresenta uma só forma. São múltiplas as maneiras como ela acontece (Sgreccia, 2009).

Na relação dita paternalista, ou genitoral, ou sacerdotal, o médico assegura ao paciente todas as intervenções que promoverão a sua saúde e o seu bem-estar. A participação do paciente nas decisões é mínima. Prevalecem as escolhas do profissional, que figura como um tutor, em detrimento daquelas do enfermo. Isso, todavia, se restringe a situações de emergência.

No modelo de relação denominado informativo, científico, engenheirista ou do usuário, o médico tem o dever de informar ao paciente todos os riscos e benefícios do tratamento. A intervenção necessária acontecerá apenas com a anuência do enfermo. Esta- 
belece-se uma relação contratual, em que o profissional da saúde reduz-se à condição de um prestador de serviços qualificado. Ela não se baseia na confiança e tem como característica principal a impessoalidade.

Na relação do tipo interpretativa, o médico tem a função de ajudar o paciente em suas escolhas. Não se limita a informar os riscos e benefícios de cada procedimento, mas busca esclarecer e aconselhar. Essa espécie de aconselhamento requer que o tempo da consulta seja estendido, o que nem sempre é possível, em razão da falta de disponibilidade do profissional e de interesses econômicos. Todavia, a principal limitação é, muitas vezes, a falta de preparo desses profissionais da saúde para cumprir essa função de aconselhamento. Isso pode criar outro problema: o paciente pode ser influenciado pelas perspectivas do médico, o que limita a interpretação e a escolha do próprio paciente.

No modelo deliberativo de relação, o médico tem o dever de informar o paciente sobre os aspectos clínicos do procedimento. Atua como um irmão mais velho, um mestre, aconselhando o enfermo e mostrando-lhe quais os valores subjetivos, como crença, convicções e características pessoais, devem ser valorados, associados aos riscos e benefícios, para decidir se aceita ou não o tratamento. $\mathrm{O}$ paciente tem sua autonomia respeitada. O que se critica, nesse modelo, é que o profissional da saúde não conhece os valores mais relevantes para cada paciente. Além do mais, o paciente busca o médico para tratar a sua enfermidade, e não para um debate moral.

A função desse profissional da saúde é oferecer apoio, seja na forma de prevenção, tratamento ou alívio da dor. Ele deve conhecer as aflições, os medos e as necessidades do enfermo e ampará-lo, pois certamente ele estará inseguro quanto ao seu futuro. A vida e a dignidade de qualquer pessoa devem ser os fundamentos de todas as relações sociais, independentemente de serem hierárquicas. Entretanto, se uma das partes envolvidas nessa discussão, ou um grupo específico, está mais bem informada do que outra, poderá haver zonas de atrito e desequilíbrio (Sztajn, 2012). A necessidade de definir condutas relativas à qualidade de vida do paciente ou ao 
seu prolongamento, assim como quaisquer outros procedimentos que, por motivos alheios à vontade do paciente e do profissional, podem alterar o modo de viver do primeiro, em razão da intervenção médico-hospitalar, devem ser discutidos pelas partes envolvidas, para esclarecimento sobre o seu conteúdo.

\section{Acepção jurídica e bioética do termo de consentimento}

A acepção jurídica do termo "consentimento", segundo De Plácido e Silva (2004), deriva do verbo latino consentire, que significa "ter o mesmo sentir, estar de acordo, concordar". Pode ser interpretada como a manifestação de vontade definitiva. O consentimento confere validade ao ato jurídico, por essa razão deve ser deferido de modo livre e com seriedade. Demonstra que o manifestante concorda com o ato que será praticado e o autoriza, conferindo poder à pessoa que irá praticá-lo. A ausência de consentimento constitui um obstáculo à realização do ato (Silva, 2004).

O consentimento diz respeito a autorizar uma pessoa a agir para determinado fim. Especialmente no caso de consentimento para procedimento médico-hospitalar, autoriza-se o profissional a atuar na esfera físico-psíquica do paciente, a fim de promover a sua saúde. É imperioso destacar que o consentimento informado não se restringe a permitir ao paciente a escolha do profissional que irá cuidar de sua saúde (Rodrigues, 2010). Ele deve receber esclarecimentos sobre o procedimento a que poderá ser submetido, para só então dar a sua autorização e manifestá-la.

A origem do consentimento não é encontrada em Hipócrates, mas constitui uma contribuição da ciência jurídica para a medicina, auxiliando-a, com os ideais emanados da teoria dos direitos humanos, na sua concretização como direito primário e fundamental (Tamayo, 2004).

A manifestação do consentimento demonstra a instrumentalização do diálogo entre o profissional da saúde e o tomador de seus 
serviços, permitindo o início da prestação médica. Essa manifestação deve ser realizada a cada nova intervenção (Kfouri Neto, 2007).

O consentimento livre e esclarecido, embora derive de autonomia, não pode ser considerado sinônimo dela, uma vez que a responsabilidade técnica e moral do profissional da saúde permanece, independentemente da adesão ou recusa do paciente ao tratamento proposto.

Ademais, uma decisão relativa à qualidade de vida deve ser tomada de modo ponderado, o que acontece somente quando são esclarecidas todas as dúvidas referentes aos procedimentos, sobre as suas consequências, os seus benefícios, os seus possíveis riscos. Essa conduta fortalece a relação médico-paciente, que é tipicamente fiduciária (Sztajn, 2012).

O médico tem o dever de informar o paciente. As dúvidas devem ser sanadas de maneira simples e de fácil entendimento. $\mathrm{O}$ paciente não possui os conhecimentos técnicos do profissional, nem conhece o conteúdo dos procedimentos médico-hospitalares. Além disso, encontra-se frágil física e psicologicamente, em razão da doença.

No entanto, é importante ressaltar que, em alguns casos, a manifestação do consentimento pode estar prejudicada por vícios da vontade do paciente, em razão de erro, intimidação ou dolo (Drummond, 2013).

A informação ao paciente, por exemplo, pode ser comunicada de modo equivocado ou pouco claro, dificultando a sua compreensão.

A intimidação poderá ocorrer quando o profissional, ao receber a recusa do paciente, argumentar que, se não for realizado o procedimento, haverá o risco de perda das coberturas contratadas junto à prestadora de serviços médico-hospitalares ou à seguradora.

O dolo é menos frequente, em razão da própria finalidade da atividade profissional, que é aliviar o sofrimento e salvar vidas. Ele ocorre quando o médico, ardilosamente, engana o paciente com o objetivo de obter a sua manifestação de vontade.

O consentimento livre e esclarecido é fundamental para demonstrar que a autonomia do sujeito foi respeitada, que ele foi informado sobre os riscos do procedimento (não maleficência) e os 
seus possíveis benefícios (beneficência) e que, se necessário, terá acesso a dados colhidos em pesquisas, a fármacos, a tratamentos, entre outros aspectos (equidade).

Esse documento é, portanto, a síntese, a corporificação dos limites bioéticos, éticos e morais, em relação aos procedimentos aos quais um paciente se submeterá, sendo garantido o respeito à dignidade humana e à vida, contribuindo para a discussão sobre os limites e princípios bioéticos.

Deve ser dada especial atenção à informação, que deve ser completa e renovada a cada ato (Sgreccia, 2009).

Só há verdadeira autonomia quando a vontade dos sujeitos da relação (médico, paciente e familiares), assim como os seus limites, estão expressos de modo claro. Apenas por meio dessa dialética é possível escolher a conduta mais adequada.

Por décadas, o consentimento informado recebeu críticas da comunidade médica, com a alegação de que, se o paciente tivesse acesso a todas as informações de modo detalhado, incluindo os menores riscos, isso geraria ansiedade e desconforto, diante da incerteza, com a consequente elevação dos índices de recusa e abandono das terapias. O termo de consentimento livre e esclarecido chegou a receber denominações pejorativas, como termo de ressentimento (Grinberg; Chehaibar, 2012).

Os diagnósticos e prognósticos, assim como os riscos, devem ser informados com prudência, tendo em conta os efeitos psicológicos sobre o paciente (Sgreccia, 2009).

Muitas vezes, a informação equivocada, transmitida de modo inadequado, em linguagem inacessível, faz que se entenda o consentimento apenas como uma etapa burocrática no tratamento da enfermidade.

Apenas esclarecer os riscos e benefícios não é suficiente. O médico deve oferecer opções de tratamento, explicando ao paciente quais as vantagens e desvantagens de cada uma delas.

Não se pode esquecer que muitos pacientes preferem o modelo de relação paternalista, confiando ao médico os destinos do tratamento. Equivocadamente, imaginam que a responsabilidade técnica, que 
é exclusiva do profissional, está sendo compartilhada com eles, ou depositam confiança no profissional e sentem-se seguros com ele, ou têm medo de receber uma má notícia, encontrando-se diante de uma situação concreta, quando antes havia apenas uma possibilidade.

Muitas vezes, o próprio profissional da saúde faz uso do termo de consentimento como instrumento preventivo, com o objetivo único de documentar que o procedimento escolhido era o mais adequado, na eventualidade de se discutir sua responsabilidade.

Respeitar a vontade do paciente, manifestada no consentimento, é essencial para a relação médico-paciente. O profissional deve sempre objetivar o bem-estar e a dignidade de quem busca seus préstimos (Hossne, 1995).

Reconhecendo a importância da relação médico-paciente e buscando preservar a autodeterminação do paciente e a autonomia técnica do médico, na Itália, o Comitato Nazionale per la Bioetica (Comitê Nacional para a Bioética) editou, em 1992, algumas diretrizes para nortear essa relação.

O termo de consentimento livre e esclarecido é um documento em que o paciente, após ter recebido todas as informações e sanado todas as dúvidas sobre um ou mais procedimentos terapêuticos e diagnósticos, manifesta seu consentimento ao médico para que sejam realizados. Na maioria das vezes, recomenda-se que a manifestação seja feita na forma escrita (Barbosa, 2014).

O documento determina que a relação estabelecida entre o profissional e o enfermo deverá ser duradoura, quando este padecer de doença relevante ou de difícil diagnóstico. O médico deve conhecer a personalidade de quem confia em seus serviços e estar preparado para auxiliá-lo. As más notícias devem ser dadas de modo prudente, de modo a evitar o agravamento da doença. As comunicações devem ser feitas de modo claro, com linguagem acessível e de fácil compreensão, de maneira que possam ser objetiva e integralmente entendidas por qualquer pessoa. O profissional não deverá se submeter ao desejo de familiares que pretendam omitir a gravidade dos prognósticos do paciente, deixando que ele próprio tome as suas decisões (Sgreccia, 2009). 
O consentimento livre e esclarecido pode inclusive ser considerado um direito da personalidade, além de representar uma garantia contra invasões à intimidade física e psíquica do paciente. A prática da bioética é caracterizada pelo respeito aos princípios ético-jurídicos, associados aos valores socioculturais, evidenciados nas tradições e nos costumes (Neves, 2003).

Na análise bioética, não existem soluções únicas, porém é necessário assegurar a toda e qualquer pessoa uma vida com condições dignas, e não é fora de propósito dizer que a dignidade, muitas vezes, está na razão direta do atendimento dos interesses mais pessoais, e cabe ao direito zelar pela garantia e manutenção de uma vida digna e pelos interesses legítimos de uma pessoa.

\section{Modos de manifestação de vontade}

A manifestação de vontade pode acontecer de diversas formas: por escrito, oral ou digitalmente, de modo explícito ou tácito, pessoalmente ou por representação. Não há uma forma especial que deva adotada, salvo quando o consentimento apresenta uma importância singular, ou quando é usada a representação, quando se deve, obrigatoriamente, adotar a forma escrita (Sgreccia, 2009).

O profissional da saúde poderá informar oralmente o paciente, o qual poderá manifestar sua aprovação ou recusa também oralmente. Contudo, essa forma de manifestação de vontade não é a mais adequada, porque alguma informação importante pode não receber a atenção necessária ou não ser entendida de maneira adequada, em toda a sua amplitude. Ademais, passados alguns dias, poderão surgir dúvidas, e o paciente, que é a parte mais frágil na relação, será ainda mais prejudicado.

Existe ainda a possibilidade de, em momento posterior, o médico precisar demonstrar que deu esclarecimentos de modo adequado ao paciente, que cumpriu com sua responsabilidade ética e jurídica, mas terá enormes dificuldades para fazer isso. 
Diante de todos esses riscos para ambas as partes da relação, a manifestação de vontade feita oralmente não é considerada a forma mais adequada. É a mais frágil de todas as modalidades, contudo, ainda assim, é melhor tê-la do que não ter o consentimento.

A manifestação expressa digitalmente apresenta pouca aplicação prática. As informações são disponibilizadas on-line, a manifestação do paciente pode ser feita por meio de gravação de áudio, vídeo, ou através de uma apresentação. Essa forma possibilita a retomada das informações, caso surjam dúvidas ou equívocos, assim como permite comprovar a sua existência, se necessário, preservando os profissionais da saúde e aqueles que usam os seus serviços.

A manifestação por escrito é mais comum do que aquela feita digitalmente e menos comum do que a oral. O consentimento do paciente é colhido por meio de assinatura. Uma via fica com o profissional ou o serviço de saúde, e outra, com o paciente.

No caso de alguns procedimentos, é exigido o uso dessa forma de manifestação de vontade, como: reprodução assistida, utilização de determinados fármacos que causam má-formação fetal e doação de órgãos e tecidos. É prudente que a recusa consciente a intervenções, procedimentos e terapias que acarretem risco à integridade física, psíquica ou à vida do paciente seja expressa por escrito, como no caso de recusa de transfusão em razão de credo religioso.

Essa espécie de consentimento livre e esclarecido também permite a comprovação de sua existência se houver essa necessidade em algum momento. Representa uma segurança para o médico e o paciente, pois fica demonstrado que foram cumpridos, nesse momento inicial, os preceitos jurídicos, éticos e bioéticos, materializados no instrumento de manifestação de vontade.

A manifestação pode ocorrer de maneira explícita, utilizando-se uma das formas de consentimento abordadas, mas também pode ser tácita, quando o paciente, após receber todas as informações acerca da terapêutica, dos prognósticos, das reações esperadas e adversas, não firma nenhum documento que expresse sua adesão ao tratamento, mas a sua conduta deixa claro, ainda que no silêncio, que ele aceita submeter-se à terapia oferecida. 
Ocorre consentimento tácito quando o enfermo se apresenta na data e no local indicados para a realização do procedimento, faz uso de algum fármaco prescrito ou não pratica atividades que foi orientado a evitar. Em todas essas situações, essas atitudes do paciente demonstram seu interesse em aderir ao tratamento, mesmo sem qualquer manifestação expressa.

É comum o próprio paciente demonstrar o desejo de aderir a uma terapêutica, mas a manifestação de vontade pessoal, embora seja a regra, não é a única possibilidade. Muitas vezes, outras ocorrências fazem que o paciente perca a capacidade de exercer a sua autodeterminação, sendo necessário que outra pessoa faça isso por ele.

O consentimento esclarecido por representação é fundamental para a relação médico-paciente nas situações em que o último está inconsciente. É o caso e de pacientes acometidos por doenças mentais, ou em estado vegetativo, e de pacientes que, apesar de conscientes, não podem agir, como nos casos de menores e incapazes.

Em caso de urgência, quando o paciente encontra-se em risco iminente de morte, a equipe médica fica desobrigada de obter a manifestação de vontade, pois um valor mais alto, a vida humana, está em risco e, nesse caso específico, aguardar o consentimento seria sem sentido, colocaria em risco a vida e a dignidade da pessoa.

\section{Capacidade e discernimento: termos sinônimos ou complementares?}

É comum perguntar-se quem pode consentir, a quem cabe a manifestação da vontade, quais são os indivíduos que podem expressar seu desejo, se existem limites à autodeterminação.

A autonomia do sujeito, quando o objeto é um procedimento médico-hospitalar, deve seguir padrões mais rígidos do que aqueles normalmente utilizados nas demais relações da vida civil (Sztajn, 2012).

O ordenamento jurídico é responsável por determinar quem está habilitado a práticar determinados atos jurídicos, aptidão que recebe o nome de capacidade. 
A capacidade permite conferir validade aos atos praticados por uma pessoa, atribuindo-lhes efeitos jurídicos que podem criar, extinguir ou modificar relações jurídicas. Portanto, não se trata de simples direito subjetivo, mas antecede a ele, é seu pressuposto (Pacifici-Mazzoni, 1871).

A norma civil inicialmente estabelece a capacidade de fato, ${ }^{2}$ de modo genérico, inerente à condição humana. Mas há também a capacidade de direito, que permite a uma pessoa exercer os atos da vida civil de modo pleno.

Não são todas as pessoas que detêm a capacidade de direito. Em um primeiro momento, o diploma civil estabeleceu o critério biológico ${ }^{3}$ para definir quem tem essa capacidade. Apenas os maiores de 18 anos a possuem, e mesmo entre eles pode haver limitações, ${ }^{4} \mathrm{o}$ que acontece quando não possuem o discernimento necessário para expressar sua vontade.

Usar o discernimento é, por meio de um critério de juízo, de valor, de prudência, diferenciar um ato prejudicial de um ato benéfico, o correto do incorreto, o conveniente do não conveniente, a conduta lícita da ilícita (Chaves, 1977).

Não apresentam discernimento pessoas com desenvolvimento mental incompleto ou reduzido. Os toxicômanos, os que habitualmente ficam ébrios e até mesmo o enfermo podem apresentar

2 Brasil. Lei n. 10.406, de 10 de janeiro de 2002. "Art. 1ำ- Toda pessoa é capaz de direitos e deveres na ordem civil."

3 Lei n. 10.406. "Art. 5ำ-A menoridade cessa aos dezoito anos completos, quando a pessoa fica habilitada à prática de todos os atos da vida civil."

4 Lei n. 10.406. "Art. 3- São absolutamente incapazes de exercer pessoalmente os atos da vida civil: I - os menores de dezesseis anos; II - os que, por enfermidade ou deficiência mental, não tiverem o necessário discernimento para a prática desses atos; III - os que, mesmo por causa transitória, não puderem exprimir sua vontade.

Art. 4- - São incapazes, relativamente a certos atos, ou à maneira de os exercer: I - os maiores de dezesseis e menores de dezoito anos; II - os ébrios habituais, os viciados em tóxicos, e os que, por deficiência mental, tenham o discernimento reduzido; III - os excepcionais, sem desenvolvimento mental completo; IV - os pródigos." 
ausência de discernimento, sendo necessário que um médico ateste sua capacidade ou incapacidade (Anderson, 2009).

No caso do consentimento, o paciente deve ter discernimento para exercer sua autonomia, compreender o significado de sua decisão e aderir ou recusar o procedimento oferecido. A função do médico é atestar se o sujeito está apto a decidir (Naves, 2002). Sem discernimento, o paciente está impedido de manifestar seu consentimento, invalidando o ato por completo.

Uma pessoa só é capaz de decidir quando consegue entender a informação que lhe é transmitida e avaliar as propostas que lhe são apresentadas, tendo em vista o resultado que espera ser obtido, segundo os seus desejos e os seus valores (Beauchamp, 1979).

O discernimento pode ser entendido como a capacidade de uma pessoa de consentir, de escolher, entre as alternativas que lhe são apresentadas, a que melhor satisfaz os seus interesses. Ele pode ser considerado outra espécie de capacidade, que deve somar-se à capacidade de direito e de fato (Pereira, 2004). Diferencia-se da capacidade civil porque nele não há um critério objetivo, como o critério etário. É necessário analisar o caso concreto para poder verificar se o indivíduo tem capacidade para expressar seus desejos, com base nos seus juízos de valores.

Cada vez mais defende-se a relativização dos critérios objetivos de capacidade, de modo a permitir ao incapaz exercer sua autonomia em decisões referentes exclusivamente aos direitos da personalidade (Teixeira, 2010).

A adoção de critérios etários e biológicos para determinar a capacidade civil muitas vezes compromete o exercício regular dos direitos da personalidade, afetando seu titular, retirando-lhe ou relativizando sua dignidade (Dadalto, 2013).

Não se pode negar que capacidade civil e discernimento são complementares, contudo não são sinônimos, pois há menores de 18 anos que conseguem valorar suas condutas de modo prudente, distinguindo de maneira adequada o que lhes é benéfico do que é prejudicial. Possuem discernimento, mas não capacidade civil. 
Algumas vezes, a capacidade civil aparece desacompanhada do discernimento. É o caso de uma pessoa maior de idade acometida de enfermidade grave que lhe causa sérios transtornos emocionais.

Desse modo, o consentimento para práticas médicas só será válido quando estiverem associados a capacidade civil e o discernimento. Em qualquer outra situação, ele não produzirá efeitos.

\section{Relevância jurídica}

Inúmeras atrocidades foram cometidas nas guerras que antecederam o Código de Nuremberg, e são inumeráveis os abusos de Tuskegee, no estado norte-americano do Alabama, cometidos em pesquisas que se estenderam do ano de 1932 até 1972. Nelas, homens negros e socioeconomicamente vulneráveis foram utilizados como cobaias, com a finalidade de identificar os efeitos da sífilis e de fármacos, as reações esperadas e adversas em seres humanos. $\mathrm{Na}$ época já havia o termo de consentimento livre e esclarecido, mas os sujeitos não recebiam esclarecimentos sobre os riscos e benefícios da pesquisa, tampouco manifestavam o seu consentimento. Diversos hospitais possuíam uma lista com os nomes dos sujeitos, verdadeiras "cobaias humanas", aos quais não devia ser ministrada penicilina, pois isso influenciaria os resultados da pesquisa (Grinberg; Chehaibar, 2012).

A ciência jurídica é responsável por impedir abusos e danos à população. Essa deve ser a principal contribuição do direito para a manutenção de uma sociedade ética, justa e igualitária.

As previsões legais sobre o tema ainda são incipientes, mas já se começa a reconhecer a necessidade de regulamentar o assunto, devido à sua importância para a sociedade atual e às consequências trágicas de sua ausência.

Como não existem leis específicas que versem sobre a necessidade de exigir o termo de consentimento em pesquisa científica, os estudiosos da bioética e do biodireito acabam buscando em leis gerais subsídios que auxiliem na estrutura jurídica do consentimento 
livre e esclarecido, como meio de defesa da autodeterminação do paciente, que é um direito fundamental, atinente à personalidade e à dignidade humana.

A Comissão Nacional de Ética em Pesquisa (Conep), órgão associado ao Conselho Nacional de Saúde (CNS), no ano de 1996 editou a Resolução n. 196/96, que estabeleceu as diretrizes éticas para pesquisas envolvendo seres humanos, dedicando o item IV especialmente a o consentimento livre e esclarecido.

Após múltiplas sugestões de diversos pesquisadores e comitês de ética em pesquisa, no ano de 2012 o Conep substituiu a Resolução n. 196/96 pela Resolução n. 466/12, que também destinou o item IV para as diretrizes acerca do consentimento livre e esclarecido.

Essas resoluções reconheceram que dar o consentimento é exercer a autodeterminação, é manter a dignidade, e estabeleceram que as informações constantes no instrumento devem estar redigidas em linguagem clara e acessível, respeitando as características culturais, a condição socioeconômica e a autonomia do manifestante.

Embora o interesse das resoluções seja a pesquisa, como não há norma própria que verse sobre o consentimento livre e esclarecido, elas podem ser usadas, por analogia, aproveitando-se o que for compatível no contexto clínico.

O Conselho Federal de Medicina também demonstrou especial interesse em garantir o respeito à autodeterminação do paciente, dedicando princípios e artigos do Código de Ética Médica ao tema.

O Código estabelece, no Capítulo I, que versa sobre princípios fundamentais, que o profissional deve aceitar as escolhas do paciente em relação à terapêutica, desde que adequadas em termos técnicos.

No Capítulo III, impõe ao médico que colha o consentimento em casos de inseminação artificial, transplante de órgãos e tecidos, esterilização, terapia e manipulação genética ou abortamento, conforme dispõe a legislação.

No Capítulo IV, proíbe o profissional de atentar contra a autonomia da vontade do paciente, que poderá recusar a terapia médico-hospitalar. 
A relação com pacientes e familiares é o tema do Capítulo $V$, que assevera que, sempre que houver possibilidade, o paciente deverá ser informado sobre as práticas diagnósticas e terapêuticas, devem ser oferecidas alternativas de tratamento, e ele deve ter a liberdade de buscar outra opinião.

Apesar da lacuna legislativa, a relevância jurídica da manifestação de vontade como pressuposto da autonomia, em respeito à dignidade humana, é uma garantia constitucional.

O inciso II do art. 5o da Constituição Federal determina que ninguém será compelido a fazer ou deixar de fazer alguma coisa se não estiver previsto em lei.

O Código Civil também dispõe acerca da necessidade de colher o consentimento para intervenção médico-hospitalar, no art. 15, ao determinar que ninguém poderá ser constrangido a aderir à terapia médico-hospitalar.

Assim, nenhuma pessoa será obrigada a se submeter à terapia, salvo se concordar com os procedimentos e intervenções. Se discordar, poderá manifestar livremente sua recusa.

No Brasil, apenas o estado de São Paulo, por meio da Lei Estadual n. 10.241, de 1999, conhecida como Lei Covas, prevê o respeito à autonomia dos usuários dos serviços de saúde, que se dá pelo consentimento informado, sendo permitido ao enfermo inclusive escolher o local de sua morte.

É cristalina a evolução normativa do instituto. Embora ainda não seja regulamentado de modo completo e específico, não se pode ignorar o avanço não só das normas, mas do próprio entendimento sobre autodeterminação. A ciência jurídica não se omitiu e, ao longo das décadas, vem cumprindo sua função e buscando disciplinar o instituto. 


\section{4 \\ DIRETIVAS ANTECIPADAS DE VONTADE COMO DISSENTIMENTO LIVRE E ESCLARECIDO E A NECESSIDADE DE ACONSELHAMENTO MÉDICO E JURÍDICO}

As diretivas antecipadas de vontade surgiram nos Estados Unidos da América, por meio de uma lei federal denominada Patient Self-Determination Act (PSDA) (Ato de Autodeterminação do Paciente), que objetivou instrumentalizar o paciente para expressar seus desejos em situações futuras em que isso não seja possível, preservando a sua autonomia e a sua dignidade mesmo em situações em que se encontre incapacitado para agir.

Atualmente, vários países, em diversos continentes, já regulamentaram as diretivas antecipadas, como Austrália, Espanha, França, Bélgica, Itália, Holanda, Uruguai e Argentina, entre outros.

Conforme veremos, no Brasil ainda não houve a normatização do documento, mas o Conselho Federal de Medicina já reconheceu sua importância em algumas resoluções. A Resolução n. 1.805/2006, de 28 de novembro de 2006, permitiu ao médico limitar ou suspender tratamentos que prolonguem a vida de pacientes em fase terminal, com enfermidades graves e incuráveis, respeitando sua vontade ou a do seu representante legal. Por sua vez, a Resolução n. 1.995/2012, de 31 de agosto de 2012, manteve as disposições estabelecidas anteriormente e regulamentou de modo mais completo as diretivas antecipadas de vontade, não impondo regras aos par- 
ticulares, apenas diretrizes éticas e morais aos médicos, que devem ser observadas no exercício da profissão.

As resoluções mencionadas comprovam o esforço do Conselho Federal de Medicina, que, fazendo uso de sua atribuição de promover, por todos os meios ao seu alcance, o perfeito desempenho técnico e moral da medicina, além do prestígio e do bom conceito na área médica, se preocupou em estabelecer critérios de conduta éticos referentes às diretivas antecipadas.

A nomenclatura "diretiva antecipada de vontade" explica-se pelas seguintes razões: o termo "diretiva" remete a orientação ou instrução; "antecipada" porque a manifestação remete a uma situação pretérita àquela em que o paciente se encontra no momento, fazendo menção ao momento em que assinou o documento; "vontade" diz respeito ao fato de os desejos do declarante serem manifestados por meio da diretiva, com base no seu discernimento e na sua capacidade de escolher, entre as opções disponíveis, aquela que melhor satisfaz as suas necessidades essenciais (Alves; Fernandes; Goldim, 2014). As diretivas antecipadas de vontade são uma manifestação livre e prévia pela qual uma pessoa, com capacidade e discernimento, renuncia a tratamentos e cuidados médico-hospitalares futuros se, por qualquer razão, na ocasião não puder expressar sua recusa.

Cristina López Sanchez (2003) complementa a conceituação do instituto:

Una directriz anticipada es un término general que contiene instrucciones acerca de los futuros cuidados médicos que ha de recibir una persona en el caso de que se vuelva incapaz de expresarlos por si misma. Esta denominación, directrices anticipadas, en realidad constituye el género que comprende dos tipos de documentos en virtud de los cuales se puede plasmar por adelantado la voluntad de la persona que los redacta. Así, por un lado, tenemos el llamada testamento vital y por otro lado, el poder médico o poder para el cuidado de la salud que se otorga a un representante.

[A diretiva antecipada é um termo geral que contém instruções sobre futuros cuidados médicos que uma pessoa irá receber na 
hipótese de se tornar incapaz de se expressar por si própria. Esta denominação, diretivas antecipadas, na realidade é um gênero que tem como espécies dois tipos de documentos, em razão dos quais a vontade da pessoa que o redige é materializada. Desse modo, por um lado, tem-se o denominado testamento vital e, por outro, o poder médico ou poder para cuidar da saúde que se outorga a um representante.] (Tradução nossa)

As diretivas antecipadas são uma hipótese de autodeterminação do paciente, o qual, fazendo uso de sua autonomia, baseado em seus valores pessoais, recusa a prática de tratamentos fúteis, em situações de terminalidade e irreversibilidade da enfermidade.

[...] la regulación de los Documentos de voluntades anticipadas representa un importante paso adelante en el respeto a la autonomía de las personas, al permitirles decidir respecto a las actuaciones sanitarias que deseen recibir, o no, en el futuro, si se encuentran en determinadas circunstancias [...].

[...] a regulamentação dos documentos de vontades antecipadas representa uma evolução importante no que diz respeito à autonomia das pessoas, por permitir-lhes decidir sobre os procedimentos médico-hospitalares que desejam receber ou não no futuro, se estiverem em determinadas circunstâncias [...]. (Tradução nossa)

Não se pode desconsiderar a necessidade de demonstrar a importância da relação médico-paciente, além da ética médica, principalmente no que diz respeito a pacientes terminais, e a importância dos cuidados paliativos, que permitem aliviar a dor do enfermo, proporcionando-lhe condições dignas na derradeira etapa de sua vida.

A doutrina estrangeira, assim como a pátria, tem demonstrado grande interesse pelo tema, reconhecendo sua atualidade e importância para a defesa dos direitos da personalidade e da dignidade humana. 


\section{O instituto no direito comparado}

As diretivas antecipadas de vontade, como já mencionado, tiveram origem no direito estadunidense, país em que a doutrina se ocupou de tecer conceitos, estabelecer regras, limites e promover a sua regulamentação.

Posteriormente, o instituto ganhou popularidade na Europa, onde assumiu novas particularidades, incorporando características culturais próprias de cada Estado. Certamente, é o continente com maior número de países que regulamentaram e fazem uso das diretivas antecipadas de vontade.

Alguns países da América Latina já possuem leis próprias dedicadas ao instituto. Naqueles em que ainda não houve a regulamentação, existem estudos e interesse, ainda que acadêmicos, na elaboração de regramento específico.

No Brasil, a doutrina sobre o tema ainda é incipiente, mas alguns estudiosos têm destinado esforços e demonstrado interesse na adoção do documento, bem como advogado pela necessidade de inserção do tema no ordenamento jurídico pátrio.

Por essa razão, é imperioso analisar a legislação internacional de países como Austrália, Finlândia, Hungria, Inglaterra, País de Gales, Alemanha, Áustria, México, Porto Rico, Venezuela, entre outros. A França possui legislação sobre o tema, mas, para autores como Dadalto (2013), não se pode considerar que seja um país que reconhece as diretivas antecipadas, pois a atuação do médico diante do instituto é discricionária, e ele pode recusar-se a cumprir a determinação do paciente.

Analisaremos a seguir as legislações de Estados Unidos, Espanha, Portugal, Holanda, Bélgica, Itália, Uruguai e Argentina, para exemplificar a experiência estrangeira e comparar sua evolução e suas características nesses países.

\section{Living will: a realidade estadunidense}

As diretivas antecipadas de vontade surgiram nos Estados Unidos, no ano de 1967, onde receberam a denominação de living will. 
Sua origem está ligada à Sociedade Americana para a Eutanásia, que adotou e disseminou a ideia de utilização de um documento no qual a pessoa pudesse expressar sua vontade relativamente a cuidados futuros de saúde e manifestar seu desejo de não submeter-se a intervenções médicas com o fim único de manutenção da vida (Leão, 2014).

A evolução do instituto teve a importante colaboração de Louis Kutner, um advogado que, no ano de 1969, propôs um novo modelo, de modo a evitar conflitos na relação médico-paciente, envolvendo pacientes terminais e seus familiares. $\mathrm{O}$ documento versava acerca de decisões prévias sobre os tratamentos aos quais eram submetidos pacientes que padeciam de doença em estágio terminal (Kutner, 1969).

O advogado defendeu a criação do documento que, além de ser bastante claro, devia atender quatro importantes finalidades: auxiliar o julgamento jurídico em processos envolvendo homicídio privilegiado por relevante valor moral e homicídio qualificado por motivo torpe, servindo como prova da conduta; preservar a autonomia e a autodeterminação do paciente que deseja morrer; servir como instrumento de declaração de vontade, pelo qual o paciente manifesta seu desejo de morrer, inclusive se futuramente estiver incapacitado para expressar seu consentimento; representar uma garantia de cumprimento da vontade do paciente (Kutner, 1969).

A primeira disposição legal sobre o instituto foi o Natural Death Act (Ato sobre Morte Natural), elaborado na Califórnia, pela Faculdade de Direito da Universidade de Yale. Após sua aprovação, algumas associações médicas locais elaboraram um Guidelines and Directive (Guia de Instruções e Diretivas), com o objetivo de orientar a conduta médica em relação às diretivas (Leão, 2004).

A norma exige que seu subscritor seja uma pessoa maior e capaz, portanto exige capacidade e discernimento. São necessárias também duas testemunhas, que devem presenciar o ato. $\mathrm{O}$ documento ganha eficácia catorze dias após sua lavratura. A diretiva tem validade limitada ao prazo de cinco anos, período a partir do qual necessita ser renovada. Ela não será válida durante o período de gravidez. 
A revogação do documento pode ser efetuada a qualquer tempo. Como particularidade, a lei exige que o estado de terminalidade seja atestado por dois médicos (Baudouin; Blondeau, 1993).

As testemunhas não podem ter vínculos sanguíneos ou matrimoniais com o declarante, nem ser beneficiárias de quinhão sucessório de qualquer natureza, situações em que estarão impedidas de participar do ato. $\mathrm{O}$ médico assistente, pessoas vinculadas a esse profissional ou ao estabelecimento de saúde em que o declarante é paciente também não podem figurar como testemunhas.

A lei entende que pessoas maiores e com discernimento têm o direito de decidir se querem ou não receber cuidados de saúde, incluindo a decisão de suspender um tratamento que garanta suporte à vida, em caso de doença terminal acompanhada de inconsciência permanente. Dessa forma, a lei preserva a autonomia do paciente em relação ao prolongamento artificial do seu processo de morte, para além dos limites naturais, o que tornou-se possível graças aos avanços biotecnológicos na área médica.

Enfim, a norma reconhece a diretiva antecipada de vontade como modo de instruir a equipe médica a manter ou suspender o tratamento de suporte de vida no caso de doença terminal.

A lei também reconhece a figura do mandatário, ao estabelecer que a pessoa pode escolher um representante para cuidar das questões referentes à sua saúde, o denominado procurador de cuidados de saúde.

A elaboração da lei californiana serviu de inspiração para outros estados norte-americanos, que também reconheceram o living will.

Anos depois, em 1991, por meio do caso Cruzan, o living will foi analisado pela primeira vez em um tribunal estadunidense. Nancy Cruzan sofreu um acidente automobilístico e ficou em estado vegetativo persistente. A família requereu a interrupção dos procedimentos de nutrição artificial que a mantinham viva. $\mathrm{O}$ caso teve grande repercussão e causou grande comoção na sociedade americana (Markus, 2014).

Devido ao clamor público gerado pelo caso Cruzan, as diretivas antecipadas do paciente ganharam importância no país, que 
aprovou a primeira lei federal que dispunha sobre o direito de sua autodeterminação, o Patient Self-Determination Act (PSDA) (Penalva, 2008).

Embora se trate de uma lei federal, ela deve ser interpretada apenas como uma diretriz que estabelece conceitos e versa sobre questões específicas que devem ser tratadas de modo semelhante em todo o território americano, uma vez que 35 estados norte-americanos já legislaram sobre o living will (Emanuel, 1990).

Nos Estados Unidos, o paciente, ao dar entrada em um centro de saúde, deve ser informado sobre os seus direitos enquanto paciente, entre eles, o de expressar sua vontade de aceitar ou recusar procedimentos e terapias na hipótese de incapacidade de manifestar seu consentimento. Esse documento recebe o nome de advance directives (diretivas antecipada de vontade). Por meio dele, o paciente manifesta sua autodeterminação. As advance directives são um gênero que apresenta três espécies: living will, declaração prévia para o fim da vida; durable power of attorney for health care (mandato duradouro para cuidados de saúde), semelhante ao mandato duradouro previsto na lei brasileira, pelo qual é nomeado um representante para administrar a saúde; e o advanced care medical directive (planejamento antecipado de tratamentos médico-hospitalares).

Discute-se, nos Estados Unidos, a ampliação das diretivas de vontade, de modo que não fiquem restritas aos pacientes terminais, mas estendam-se, de modo indistinto, a todos os pacientes, por meio do advanced care medical directive, através do mandato duradouro (Penalva, 2008). Nesse caso, o representante de saúde nomeado será responsável por cumprir a vontade determinada nesse documento. Se não houver o documento, ele expressará, com base no seu convívio com o mandatário, qual seria a sua vontade se pudesse manifestá-la.

\section{Instrucciones previas: a experiência espanhola}

Na Espanha, o documento de autodeterminação recebeu o nome de instrucciones previas. O interesse por regulamentar o instituto 
surgiu por iniciativa da Associación pro Derecho a Morir Dignamente que, em 1986, elaborou um modelo do documento, o qual, anos depois, após ampla discussão, foi incluído no ordenamento jurídico espanhol (Cantero Martínez, 2005).

No Código de Ética Médica espanhol, que vigora desde 1999, já havia indícios de regulamentação das instrucciones previas. Seu art. 27 estabelece que, quando o paciente não é capaz de tomar decisões referentes a procedimentos médicos, a equipe médica deverá respeitar os desejos manifestados anteriormente por ele ou por seus representantes e responsáveis legais. ${ }^{1}$

Todavia, o marco inicial legislativo foi decretado apenas uma década e meia mais tarde, no ano 2000, com o advento da Convenção sobre os Direitos do Homem e a Biomedicina na Espanha, ou Convênio de Oviedo, como é mais conhecida.

O Convênio de Oviedo, em seu art. 9o, estabeleceu que deverá ser considerada a vontade do paciente que tenha se manifestado anteriormente sobre uma intervenção médica se no momento da intervenção ele esteja incapacitado para expressá-la.

O Convênio ganhou grande importância por reconhecer o direito do paciente à autodeterminação, levando em conta que, em razão da constante evolução do conhecimento e da tecnologia biomédica, novos procedimentos surgem e as determinações constantes na manifestação de vontade perdem a sua validade. Outro ponto que merece destaque é o fato de ter sido o primeiro documento legislativo internacional que vinculou juridicamente os países que o subscreveram, ainda que seja necessária a edição de normas específicas para cada país.

Contudo, mesmo com a previsão das instrucciones previas no ordenamento jurídico espanhol, as diretivas precisaram ser normatizadas por meio de leis locais, com vigência e competência de-

1 España. Organización Médica Colegial. Código de Etica y Deontología Médica. "Art. 27 - [...] y cuando su estado no le permita tomar decisiones, el médico tendrá en consideración y valorará las indicaciones anteriores hechas por el paciente y la opinión de las personas vinculadas responsables." 
terminada por cada uma das comunidades autônomas espanholas. Andaluzia, Aragón, Catambria Extremadura, Galícia, La Rioja, Madrid, Navarra e Valencia são algumas comunidades que regularam o instituto. Apesar de as disposições legais terem conservado as linhas mestras das instruciones, apresentam grandes diferenças em relação a elas:

Dezesseis comunidades autônomas regulamentaram o tema. Onze utilizam a nomenclatura voluntades antecipadas e somente cinco fazem uso do termo instrucciones previas.

- Andaluzia, Navarra e Valencia estabeleceram que a legitimidade para elaboração do documento está restrita ao discernimento e permite sua elaboração por pacientes menores de idade.

- A norma editada em Madri faz distinção entre instrucciones previas e mandato duradouro, enquanto a legislação de Navarra diferencia as declarações prévias para o fim da vida e as diretivas antecipadas de vontade.

- Todas as comunidades exigem o documento na forma escrita, sua anexação ao prontuário do paciente, um procurador ou representante.

- Um percentual considerável de comunidades permite ao outorgante dispor sobre temas como doação de órgãos e destino do cadáver (Penalva, 2008).

Com relação às disposições sobre doação de órgãos e destino do corpo após o falecimento, a doutrina brasileira considera que são temas estranhos às diretivas antecipadas de vontade e que devem ser dispostos em documento próprio.

No final do ano de 2002, foi editada a Lei n. 41/2002, que dedicou os cinco itens do seu art. 11 às instrucciones previas. A norma se preocupou em estabelecer as linhas gerais do instituto. As instrucciones previas são destinadas à equipe médica e manifestam a vontade do subscritor de não ser submetido a tratamentos fúteis que busquem prolongar sua vida de modo artificial. A lei reafirmou a possibilidade de o outorgante dispor sobre doação de órgãos e sobre 
o destino do seu corpo após o seu falecimento. Permite-lhe ainda nomear um representante, um procurador para saúde, por meio de um mandato duradouro, assim como a revogação do documento a qualquer momento.

A forma escrita é obrigatória nas instrucciones previas, mas é optativo utilizar instrumento público ou privado. Caso seja feita a opção por instrumento público, a elaboração do documento poderá ser feita perante notário, em cartório, ou por meio do Registro Nacional ou da Administração Pública. Se for escolhida a confecção do documento por instrumento privado, será obrigatória a presença de três testemunhas (Dadalto, 2013).

A lei é expressa ao estabelecer que não são admitidas disposições que contrariem o ordenamento jurídico, assim como práticas contrárias à vontade do outorgante.

A Lei n. 41/2002 dispõe sobre o critério etário para atribuir legitimidade ao autor das instrucciones previas. Menores de idade não podem elaborar o documento, de modo contrário ao que algumas comunidades autônomas estabelecem em suas legislações. Contudo, a lei reitera a obrigatoriedade de o documento ser anexado ao prontuário do paciente (Leão, 2013).

Passados alguns anos, diante da necessidade de regulamentar o item 5 do art. 11 da Lei n. 41/2002, foi editado o Decreto n. 124/2007, que estabeleceu a criação do Registro Nacional de Instrucciones Previas e do arquivo de dados de caráter pessoal (Leão, 2013). O decreto determinou que o acesso ao Registro Nacional será restrito ao subscritor das instrucciones previas, ao seu representante legal, ou a terceiro designado pelo outorgante para esse fim, aos responsáveis pelos registros autônomos e às pessoas que a autoridade sanitária da comunidade autônoma correspondente ou o Ministerio de Sanidad y Consumo designar (Leão, 2013).

O paciente, em comunidades autônomas em que o instituto não está regulamentado, deverá recorrer à autoridade de sua comunidade, requerendo que seu documento de instrucciones previas seja remetido ao Registro Nacional, onde será feita uma inscrição provisória e, posteriormente, a sua notificação à comunidade autô- 
noma. A execução do documento é obrigatória e a atuação da equipe médica está vinculada ao seu conteúdo, independentemente da comunidade autônoma a que o paciente pertence (Dadalto, 2013).

\section{Nontreatment directives: o vanguardismo holandês}

A Holanda adotou uma atitude de vanguarda no que se refere à tutela dos direitos de pacientes em terminalidade. Já reconhecia seus direitos mesmo antes do Convênio de Oviedo, do qual é signatária, mas que não ratificou.

O pioneirismo holandês na defesa dos direitos dos pacientes iniciou-se com o act on the medical treatment contract (ato sobre contrato de tratamento médico), de 1o de abril de 1995, que ingressou no ordenamento jurídico como parte do Código Civil holandês, almejando que o paciente receba esclarecimentos sobre seus direitos e auxiliá-lo em sua defesa.

As disposições legais não ficaram restritas às relações médicas pautadas em contratos, mas estenderam-se aos direitos oriundos de práticas sanitárias, que em razão de sua natureza são alheias ao contrato.

A legislação holandesa reconhece a importância do consentimento informado, o qual divide em duas partes: informação e consentimento. A informação é fundamental para o exercício da autonomia. Apenas o paciente corretamente esclarecido é capaz de manifestar seu consentimento, que pode ser expresso ou presumido.

Sua grande inovação é reconhecer a validade das diretivas antecipadas de vontade, que denominam de nontreatment directives (diretivas sobre renúncia de tratamento), mas que não se confundem com uma declaração para eutanásia, permitida no país, e devem ser apresentadas na forma escrita.

O documento registra a recusa, em circunstâncias específicas, a alguns tratamentos e procedimentos médico-hospitalares, como a reanimação mecânica, quando se constituírem em procedimentos extraordinários, de obstinação terapêutica, que em nada contribui- 
rão para a cura da doença ou para melhorar a qualidade de vida do paciente, apenas estenderão o tempo do processo de morte.

O objetivo do documento é dar a conhecer ao médico quais tratamentos o signatário aceita ou não receber se, em algum momento, no futuro, estiver incapacitado para se expressar livremente.

A lei não estabelece os requisitos específicos das diretivas antecipadas de vontade, apenas traça linhas gerais do instituto, conferindo ao médico a missão de interpretar e, principalmente, cumprir a vontade do paciente expressa no documento.

$\mathrm{Na}$ hipótese de não haver o documento, o médico deve ponderar qual seria a vontade do paciente naquela situação específica, bem como ouvir as declarações dos parentes, de modo que os seus desejos sejam cumpridos, respeitando-se sua autonomia e autodeterminação.

Outra inovação é que, na Holanda, são considerados capazes os maiores de 16 anos. Contudo, pessoas maiores de 12 anos têm permissão para manifestar sua oposição a que seu representante legal tome decisões relativas a procedimentos médico-hospitalares. Basta que expressem seu desejo para que o representante seja afastado.

A contribuição holandesa para o desenvolvimento das diretivas antecipadas de vontade também é de grande relevância, visto seu pioneirismo em tutelar a autonomia e a autodeterminação, assim como a efetivação dos demais direitos do paciente, associada à incorporação dos valores do Convênio de Oviedo, do qual o país também é signatário.

\section{Déclaration anticipée de volonté: o pioneirismo belga}

A Bélgica foi o primeiro país a regulamentar a déclaration anticipée de volonté, nome do instituto no país, após o advento do Convênio de Oviedo. A lei de direitos do paciente é datada de agosto de 2002 e contém dezenove artigos para regulamentar os cuidados de saúde.

A legislação tutela a autonomia e a autodeterminação do paciente. Para tanto, assegura o direito à informação sobre o conteúdo 
e as consequências dos procedimentos e tratamentos sanitários, por meio de uma linguagem acessível e de fácil compreensão. $\mathrm{O}$ paciente pode recusar tratamentos fúteis e obstinados se estiver em fase terminal e a sua situação for irreversível.

A lei belga determina que o paciente menor seja representado pelos seus representantes legais para a manifestação do seu consentimento. No caso de paciente maior de idade que se encontra incapacitado para manifestar-se, deverá ser representado pela pessoa por ele nomeada por meio de procuração. Há, portanto, o reconhecimento do procurador de saúde, por meio de mandato duradouro, que poderá ser redigido pelo paciente ou pelo seu procurador. No documento deve constar a data de sua elaboração e a assinatura de ambos.

Se não houver o mandato duradouro, deverá ser considerado representante do paciente seu cônjuge ou companheiro e, na ausência deste, o familiar com grau de parentesco mais próximo. Caso o representante se recuse a exercer o seu papel, ou exista conflito entre o desejo do paciente e o do representante, o médico deverá levar em consideração o melhor interesse do paciente (Federal Comission on Patients Rights, 2007).

A legislação ainda estabelece que a déclaration anticipée de volonté seja renovada a cada cinco anos, sendo consideradas inválidas as declarações datadas com prazo superior ao legal, assim como aquelas que contrariem o ordenamento jurídico (Bélgica, 2002).

O documento poderá ser revogado a qualquer tempo, antes do prazo de cinco anos, bastando que o declarante manifeste seu desejo de dispor de modo distinto do previsto na diretiva.

Há ainda a previsão da participação de duas testemunhas, para conferir validade ao ato e garantir a veracidade das informações, as quais não podem ter interesses pessoais ou patrimoniais na morte do declarante.

A importância da Bélgica ao legislar sobre o tema não se restringe ao vanguardismo, mas em reconhecer, após o Convênio de Oviedo, a importância do mandato duradouro e das declarações prévias para o fim da vida, tutelando o direito do paciente à autodeterminação. 


\section{Directivas antecipadas de vontade: a experiência portuguesa}

A Resolução da Assembleia da República n. 01/2001 levou Portugal a ratificar a Convenção Internacional de Direitos Humanos e Biomedicina. No ano de 2008, a edição de novo Código Deontológico, aplicado à área médica, demonstrou a preocupação do país com as diretivas antecipadas de vontade. Em 2012, o instituto foi regulamentado por meio da Lei n. 25/2012.

A atuação da Associação Portuguesa de Bioética (APB) foi fundamental para a adoção das diretivas antecipadas de vontade, com base em diversos documentos, como o parecer P/05/APB/06 sobre os fundamentos do testamento vital; o projecto $\mathrm{P} / 06 /$ $\mathrm{APB} / 06$ sobre as directivas antecipadas de vontade; o Guidelines $\mathrm{P} / 11 / \mathrm{APB} / 08$; o parecer $\mathrm{P} / 16 / \mathrm{APB} / 09$ sobre as directivas antecipadas; o estudo E/17/APB/10 sobre o testamento vital; e a proposta $\mathrm{P} / 19 / \mathrm{APB} / 10$ sobre o modelo de documento de directivas antecipadas.

O primeiro dos pareceres citados, emitido pela Associação Portuguesa de Bioética (APB), fazia referência à recusa de transfusão sanguínea por parte de testemunhas de Jeová, mas também serviu para fixar as bases das diretivas antecipadas de vontade, enquanto os demais documentos serviram para delimitar conceitos, estabelecer limites e delinear o instituto (Dadalto, 2013).

Deve-se também destacar a colaboração do Código de Deontologia Médica português, editado em 2008, ao estabelecer, no art. 46, que a conduta médica deve obedecer à autodeterminação do paciente, em especial se houver um documento escrito em que seu desejo esteja registrado. Prescreve ainda que, embora o médico não esteja obrigatoriamente vinculado ao desejo do menor com discernimento, deverá levá-lo em conta no momento de decidir sobre o tratamento. Reconhece a importância da consulta a representantes legais e familiares, na hipótese de o paciente estar incapacitado de manifestar sua vontade, com o propósito de respeitar sua autonomia, buscando sempre atender aos melhores interesses dele. 
Posteriormente, a Lei 25/2012 regulamentou o instituto, que sofreu clara influência do direito norte-americano e do espanhol, o primeiro por ter sido o criador do instituto, o segundo em razão da proximidade territorial, cultural e linguística dos países.

A grande inovação da lei portuguesa foi a criação do Registro Nacional de Directivas Antecipadas de Vontade (Rentev), responsável por centralizar o armazenamento dos documentos e facilitar sua eficácia. O médico responsável pelo tratamento do paciente pode consultar a sua base de dados e saber de sua existência. Após tomar conhecimento do conteúdo da diretiva, a equipe médica deve atuar de modo a atender à vontade dele.

Contudo, percebe-se um equívoco técnico: as directivas antecipadas de vontade e o testamento vital (conjunto de declarações prévias para o momento do final da vida) são tratados como sinônimos, quando, na realidade, não o são. A lei portuguesa reconhece a figura do procurador para cuidados de saúde e do mandato duradouro, mas como um documento à parte, que não integra a directiva antecipada de vontade. Outra especificidade da lei portuguesa é o prazo de validade do documento, restrito a cinco anos, embora possa ser revogado a qualquer tempo (Dadalto, 2013).

Portugal e Brasil são países muitos próximos, não apenas por razões históricas, pela língua, pela cultura ou pela religiosidade, mas principalmente por serem resistentes a novidades. A regulamentação do instituto em Portugal mostra a possibilidade de a diretiva antecipada de vontade receber o mesmo tratamento no Brasil.

\section{A dichiarazione anticipata di tratamento: a experiência italiana}

A Itália é mais uma das nações que subscreveu o Convênio de Oviedo, reconhecendo a necessidade de garantir ao paciente o direito de autodeterminação por meio de um documento em que sua vontade esteja manifestada. Contudo, até o presente momento, tal convênio não foi ratificado pelo país, apesar de a Lei n. 145/ 2001 ter autorizado o presidente da República a ratificar a Convenção. Não há também nenhuma lei específica sobre o tema. 
Todavia, a Itália demonstra interesse em garantir que a vontade do paciente seja respeitada. O Código de Ética Médica italiano, em seu art. 34, estabelece que o médico, se o paciente estiver incapacitado de manifestar sua vontade e encontrar-se em risco de morte, deve levar em conta o desejo previamente manifestado por ele. ${ }^{2}$

Já o art. 37 do referido diploma, de modo semelhante ao seu correspondente brasileiro, propõe que o médico adote práticas de ortotanásia, proibindo condutas fúteis, próprias da distanásia. ${ }^{3}$

Dessa forma, o Código Deontológico introduziu o dever ético dos médicos de respeitar a autodeterminação do paciente. Contudo, essa disposição tem sua eficácia restrita aos profissionais da saúde.

A Constituição Federal italiana, em seu art. 32, estabelece que ninguém será obrigado a se submeter a um procedimento sanitário, salvo por disposição legal, e a lei em nenhum caso poderá violar o respeito à pessoa humana. ${ }^{4} \mathrm{~A}$ obstinação terapêutica no país, carac-

2 Federazione Nazionale degli Ordini dei Medici Chirurghi e degli Odontoiatri. Códice de Deontologia Medica. "Art. 34 - Autonomia del cittadino - Il medico deve attenersi, nel rispetto della dignità, della libertà e dell'indipendenza professionale, alla volontà di curarsi, liberamente espressa dalla persona Il medico, se il paziente non è in grado di esprimere la propria volontà in caso di grave pericolo di vita, non può non tenere conto di quanto precedentemente manifestato dallo stesso. Il medico ha l'obbligo di dare informazioni al minore e di tenere conto della sua volontà, compatibilmente con l'età e con la capacità di comprensione, fermo restando il rispetto dei diritti del legale rappresentante; analogamente deve comportarsi di fronte a un maggiorenne infermo di mente."

3 Ibid. "Art. 37 - Assistenza al malato inguaribile - In caso di malattie a prognosi sicuramente infausta o pervenute alla fase terminale, il medico deve limitare la sua opera all'assistenza morale e alla terapia atta a risparmiare inutili sofferenze, fornendo al malato i trattamenti appropriati a tutela, per quanto possibile, della qualità di vita. In caso di compromissione dello stato di coscienza, il medico deve proseguire nella terapia di sostegno vitale finchè ritenuta ragionevolmente utile."

4 Itália. Costituzione della Repubblica Italiana. "Art. 32 - La Repubblica tutela la salute come fondamentale diritto dell'individuo e interesse della collettività, e garantisce cure gratuite agli indigenti. Nessuno può essere obbligato a un determinato trattamento sanitario se non per disposizione di legge. La legge non può in nessun caso violare i limiti imposti dal rispetto della persona umana." 
terizada por uma intervenção penosa e aflitiva ao paciente, recebe o nome de accanimento terapeutico, em referência à obstinação e ao esforço dos caninos, utilizados para a manutenção da vida, ainda que inviável (Tepedino; Schreiber, 2009).

Por essa razão, e demonstrando preocupação com a tutela dos interesses do paciente, o Comitê Nacional de Bioética, no ano de 2003, criou um documento análogo às diretivas antecipadas de vontade, ao qual denominou dichiarazione anticipata di tratamento, também chamado de testamento biologico, testamento di vita, direttive anticipate, ou volontà previe di tratamento (Calò, 2008).

Há condições para a elaboração da dichiarazione anticipata di tratamento: o subscritor deve ser maior de idade e capaz; a forma de ser escrita, com caráter público; não pode haver qualquer tipo de pressão ou coação familiar ou social; não pode dispor sobre eutanásia ou outras manifestações que contrariem as normas legais ou os dispositivos éticos; o paciente deve ser obrigatoriamente orientado por um médico e o seu texto deve ser objetivo, sem omissões e sem deixar margem a interpretações dúbias no futuro, a fim de preservar o real interesse do declarante (Dadalto, 2013).

A Itália, por meio de decisões jurisprudenciais, também reconhece o mandato duradouro, com a nomeação de um representante da saúde que recebe o nome de amministratore di sostegno, que responderá pelo mandante se no futuro encontrar-se incapacitado para manifestar seu desejo, devendo agir em consonância com as orientações expressas dele (Zanchetta, 2012).

Dois casos emblemáticos da jurisprudência italiana ganharam repercussão internacional, tendo como protagonistas Piergiogio Welby e Eluana Englaro.

Piergiorgio Welby era um artista e ativista italiano que, na década de 1960, com 17 anos, foi diagnosticado com uma doença degenerativa, a qual evoluiu e, a partir de 1997, incapacitou-o a respirar sem auxílio de aparelhos (Dadalto, 2013). Welby se transformou em um ativista do movimento de direito a morrer, e declarou publicamente seu desejo de recusar o tratamento médico que o mantinha vivo. 
Em dezembro de 2006, alguns meses após a declaração pública de Welby, o médico anestesista Mario Riccio, que padecia de esclerose lateral amiotrófica, doença degenerativa semelhante à dele, decidiu acatar a determinação de Welby, convencido de que sua atuação como médico era lícita e de que a manifestação de vontade do artista estava isenta de coação, pressão social ou familiar.

O caso gerou intenso debate jurídico e político, e culminou com a absolvição do médico pela juíza Zaira Secchi, do Tribunal de Roma, que entendeu que Riccio não cometeu crime ao desligar os equipamentos que, por ventilação artificial, mantinham a vida de Welby. A juíza argumentou que o paciente havia manifestado seu desejo de interromper o tratamento médico e que esse é um direito constitucional, inexistindo, portanto, homicídio. O médico havia cumprido um dever profissional, atendendo ao desejo do paciente (Goldim, 2014).

Semelhante ao caso Welby é o caso Eluana Englaro, uma italiana que, aos 22 anos, após um acidente automobilístico ocorrido em 1992, entrou em um estado vegetativo persistente, sendo artificialmente mantida viva.

O pai de Eluana, Beppino Englaro, iniciou uma batalha judicial para que fosse interrompida a nutrição artificial e o suporte de vida artificial que mantinham sua filha viva.

Após uma longa demanda, com recusas iniciais do Tribunal de Apelação de Milão, em 1999, e, posteriormente, do Tribunal de Cassação, em 2005, a alta corte italiana, em 2008, permitiu que Beppino Englaro, amministratore di sostegno e pai de Eluana, agisse como representante da sua filha, incapacitada de se manifestar, e recusasse os recursos artificiais que mantinham-na viva (Araujo, 2009).

Os dois casos demonstram que, embora não exista uma lei específica sobre as dichiarazione anticipata di tratamento, elas já estão consolidadas nos tribunais, na doutrina e na jurisprudência italiana, sendo reconhecidos e tutelados os direitos dos pacientes à autodeterminação. 


\section{Uruguai e Argentina: as inovações na América Latina}

Argentina e Uruguai são países latino-americanos que possuem legislação que regulamenta as diretivas antecipadas de vontade.

O Uruguai editou a Lei n. 18.473/2009, que dedica onze artigos ao instituto. A norma não traz grandes inovações. Reconhece a competência de toda pessoa maior de idade e com discernimento de elaborar uma declaração prévia para o fim da vida, manifestando seu desejo de recusar futuros tratamentos médicos que prolonguem seu processo de morte.

A lei faz uma ressalva aos cuidados paliativos, que devem ser mantidos para assegurar o bem-estar, a qualidade de vida e a dignidade do paciente. Ademais, inova ao prescrever a possibilidade de um consentimento prévio a tratamentos e práticas obstinadas que objetivem prolongar a vida, ainda que com sacrifício da sua qualidade, em nítido respeito à autonomia da vontade do paciente.

A legislação uruguaia estabelece alguns critérios para a elaboração das diretivas antecipadas de vontade: devem obrigatoriamente ser apresentadas na forma escrita; o subscritor deve ser maior e capaz; é obrigatória a presença de duas testemunhas, que não podem ser o médico que acompanha o paciente ou qualquer funcionário da instituição de saúde em que ele está internado; o documento deve ser anexado ao histórico clínico do paciente; a declaração de vontade pode ser revogada a qualquer momento e por qualquer meio, sendo necessário dar ciência ao médico, que se encarregará de incluir a nova orientação no histórico clínico do declarante (Leão, 2013).

A lei também prevê a figura de um representante de saúde, nomeado por meio de mandato duradouro. O representante deve ser pessoa maior e dotada de discernimento, sendo responsável pelo fiel cumprimento das determinações constantes na diretiva, se o outorgante encontrar-se em situação que o impeça de manifestar seu desejo ou decidir sobre o tratamento.

Todo e qualquer tratamento apenas poderá ser interrompido após prévia comunicação da determinação de suspensão à Comis- 
são de Bioética da instituição de saúde, que terá o prazo de 48 horas para decidir pelo deferimento ou recusa do pedido. A ausência de pronunciamento da Comissão é considerada aprovação tácita à interrupção do tratamento (Leão, 2013).

$\mathrm{O}$ médico deve atuar tendo em vista o desejo do paciente. $\mathrm{Na}$ hipótese de conflitos éticos, morais, religiosos ou pessoais que não lhe permitam cumprir o que estabelece a diretiva, ele deverá ser substituído por outro.

A Argentina também demonstra bastante interesse pelo tema. É o país sul-americano com maior produção doutrinária acerca das instrucciones previas (diretivas antecipadas de vontade), que nele também recebem o nome de directivas antecipadas del paciente para tratamentos biomédicos. Oinstituto foi inicialmente regulamentadoem âmbito regional e, posteriormente, uma lei federal foi editada estabelecendo o seu fundamento e os seus conceitos com eficácia nacional.

A Província de Rio Negro, por meio da Lei n. 4.263/2007, foi a primeira a regulamentar as diretivas antecipadas de vontade na Argentina. Além de delimitar conceitos e fundamentos, determinou a criação do Registro de Diretivas Antecipadas de Vontade, com competência provincial. Estabeleceu também a necessidade de a declaração ser anexada à primeira folha do histórico clínico do outorgante, podendo ser revogada a qualquer tempo, inclusive tacitamente, no caso de ele manifestar seu consentimento à realização de tratamento, contrariamente ao que consta na diretiva, o que demonstra a maturidade do instituto no país vizinho (Dadalto, 2013).

A lei proíbe disposições de vontade contrárias à legislação, assim como aquelas cujo conteúdo verse sobre a recusa a cuidados paliativos, como analgesia, assim como a nutrição ou hidratação por vias naturais.

A norma reconhece a existência do mandato duradouro, pelo qual será nomeado um representante para o outorgante, que tomará decisões no seu lugar caso esteja incapacitado para manifestar sua vontade. A lei inova ao permitir que o ex-cônjuge ou ex-companheiro desempenhe essa função, mesmo após a dissolução da sociedade conjugal (Bostiancic, 2008). 
A Província de Buenos Aires também empreendeu esforços no sentido de regulamentar o instituto. A criação do Registro de Atos de Autoproteção de Prevenção de uma Eventual Incapacidade, por parte do Conselho Diretivo de Escrivães da Província de Buenos Aires, no ano de 2004, pode ser considerada o seu marco inaugural (Dadalto, 2013).

Os atos de autoproteção são manifestações de pessoa maior e com discernimento, nos quais ela faz declarações prévias para o final da sua vida e referentes ao seu patrimônio, na hipótese de futuramente encontrar-se incapacitada para expressar sua vontade (Brandi, 2004).

A Lei n. 26.529/2009, que versa sobre os diretos do paciente, regulamentou directivas antecipadas em todo o território argentino. Ela é composta por 25 artigos, dos quais apenas um trata as directivas antecipadas; os outros versam sobre os direitos do paciente em relação aos profissionais e às instituições de saúde.

A lei estabelece, em seu art. 11, que toda pessoa maior e com discernimento poderá elaborar as directivas antecipadas com referência aos tratamentos de saúde que futuramente desejará receber ou recusará, sejam preventivos ou paliativos. As directivas vinculam a atuação médica e não serão acatadas apenas na hipótese de contrariarem a legislação, como no caso de prática de eutanásia, quando serão consideradas nulas.

A Lei n. 26.529/2009 teve sete artigos alterados pela Lei n. 26.742/2012, que ficou conhecida como lei da "morte digna", a qual preocupou-se em evitar o encarniçamento terapêutico, humanizando a relação médica; garantir o respeito à autonomia do paciente e à sua autodeterminação; evitar tratamentos fúteis, quando não houver mais chance de cura; assegurar a adoção de cuidados paliativos, que aliviam o sofrimento do paciente; permitir a renúncia a tratamentos que visam prolongar de maneira artificial o processo de morte (Sociedade Brasileira de Bioética, 2012).

A lei isenta de responsabilidade administrativa, civil ou penal os médicos que atuam sem extrapolar ou transgredir os limites legais do instituto. 
Argentina e Uruguai são países que já legislaram sobre o direito à autonomia e autodeterminação dos pacientes terminais, reconhecendo seu direito de decidir sobre o início e a continuidade de tratamentos que poderão ser oferecidos a eles na fase final de sua vida, que visem o prolongamento do processo de morte.

\section{As diretivas antecipadas de vontade no contexto brasileiro: gênero e espécies}

No Brasil, a doutrina sobre o tema ainda é incipiente, mas a discussão começa a ganhar força e interesse. Poucos são os autores que se aprofundam no tema, e as propostas legislativas ainda esbarram na burocracia da política e adormecem nos gabinetes dos legisladores.

Conforme já exposto, o instituto já está normatizado em diversos países europeus, bem como nas Américas. Recentemente, o Conselho Federal de Medicina, por meio da Resolução n. 1.995/2012, estabeleceu o marco inicial para a regulamentação do instituto no Brasil.

As diretivas antecipadas de vontade são um documento elaborado por pessoa capaz no qual manifesta antecipadamente seu consentimento ou recusa a cuidados terapêuticos, diante da possibilidade de no futuro estar incapacitada para fazê-lo. Assim, as disposições são anteriores à recomendação da intervenção médica (Barbosa, 2011-2013).

Renata de Lima Rodrigues (2013) assim conceitua as diretivas antecipadas de vontade:

[...] são determinações prévias dadas por certas pessoas - estando elas ou não na condição de pacientes no momento de sua elaboração -, que devem ser cumpridas, ante uma situação na qual elas se tornem incompetentes para decidir o cuidado de si mesmas, indicando suas preferências de tratamento ou até mesmo autorizando uma terceira pessoa a tomar decisões por elas. (p.48) 
As diretivas antecipadas são comumente confundidas com mandato duradouro e declaração prévia de vontade para o fim da vida, ou testamento vital, como é popularmente conhecido o instituto, contudo é imperioso destacar que as diretivas são um gênero, e o mandato e a declaração, suas espécies. A seguir abordaremos de modo mais detalhado esses institutos.

\section{Declaração prévia de vontade para o fim da vida}

Trata-se da espécie de diretiva antecipada de vontade mais conhecida. Tem origem no living will do direito norte-americano. No Brasil, é conhecida como testamento vital, provavelmente pela tradução literal do nome do instituto em inglês.

A declaração prévia consiste na manifestação de vontade de um paciente de aceitar ou recusar tratamentos se estiver sofrendo de uma doença incurável, encontrar-se em estado irreversível e terminal ou em estado vegetativo permanente, e, em consequência, estiver impossibilitado de manifestar livremente sua vontade (Dadalto, 2013).

É imperioso ressaltar que nesse documento não há nenhuma solicitação de intervenção que objetive abreviar a morte, apenas recusa a procedimentos que prolonguem o processo de morte, gerando sofrimento e dor, retirando a dignidade da pessoa, fazendo que estar vivo seja um dever, e não um direito. As terapias que visam tratar o paciente, diminuir a dor, aliviar o sofrimento, oferecer-lhe amparo e tranquilidade são mantidas. A suspensão desses esforços extraordinários que tentam, a qualquer custo, curar o paciente quando isso não é mais possível, recebe o nome de suspensão de esforço terapêutico (SET). Nesse tipo de conduta, não é o fármaco utilizado para analgesia que levará o paciente à morte, em razão de overdose, mas sim a própria doença. O medicamento apenas traz alívio, auxiliando no tratamento (Ribeiro, 2006).

O objetivo do documento é resguardar a dignidade nesse momento de aflição, preservando o direito da pessoa à manifestação de sua vontade e a sua autodeterminação. Assim, o paciente poderá, 
com discernimento e capacidade civil, manifestar-se previamente em relação a tratamentos, aceitando-os totalmente ou com limites, ou recusando-os, assim como em relação a não oferta de suporte vital, retirada de suporte vital e ordem de não reanimação, ou não ressuscitação mecânica (Furtado, 2003).

A não oferta e a retirada de suporte vital são temas que causam grande controvérsia. Muitos entendem que a não oferta ou retirada de suporte vital poderiam configurar-se como eutanásia, pois o abreviamento da vida seria consequência de uma ação direta do profissional da saúde.

Barroso e Martel (2010) defendem que a não oferta de suporte vital, a retirada de suporte vital e a ordem de não ressuscitação integram a limitação a tratamentos constante na declaração. Esclarecem que o suporte vital consiste em mecanismos artificiais que permitem a manutenção da vida quando o organismo já não consegue mais desempenhar suas funções, como é o caso do sistema de alimentação e hidratação artificial e do sistema de ventilação mecânica. A ordem de não ressuscitação diz respeito à não reanimação de um paciente que se encontra em estágio terminal, irreversível, com moléstia crônica e incurável.

A declaração prévia de vontade para o fim da vida guarda estreita relação com a fronteira que divide o término da vida e o início da morte, uma das questões existenciais mais tormentosas para o ser humano e poucas vezes aceita no âmbito psicanalítico (Zimerman, 2010).

López Sánchez (2003) aponta os principais objetivos da declaração prévia de vontade para o fim da vida: a garantia de que os reais desejos do paciente sejam observados e respeitados no fim da sua vida e a segurança jurídica proporcionada ao médico ao atuar em situações em que há manifestação de vontade que confrontam com outros valores e interesses (Dadalto, 2013).

A declaração prévia tem efeito vinculante aos médicos, profissionais da saúde, procuradores de saúde, familiares e demais interessados (Dadalto, 2013). Esse efeito é fundamental para evitar uma batalha jurídica, na hipótese de o médico se recusar a cumprir 
o que determina a declaração, o que iria contra a natureza e até mesmo a razão de existir do instituto e abalaria a fidúcia que alicerça a relação médico-paciente (Rodotà, 2007).

Existem linhas mestras que devem estar presentes nas declarações prévias para o fim da vida. Luciana Dadalto (2013) elenca cinco pontos essenciais em sua elaboração: valores e desejos; decisões sobre o fim da vida; disposições outras; diretrizes para a equipe médica; e revogação.

Os valores e desejos expressam a intenção do declarante ao elaborar o documento, deixam claro quais são os seus valores e as suas intenções, o que ajuda a equipe médica e o representante para saúde na sua atuação.

As decisões sobre o fim da vida cumprem a função de indicar, de modo genérico, as patologias/situações em que o declarante recusa tratamentos e procedimentos médicos.

No documento podem constar ainda outras disposições que versem sobre o local em que o declarante deseja passar seus últimos dias, se deseja ser enterrado ou cremado, e pugna pela validade do documento.

As diretrizes para a equipe médica consistem na indicação dos procedimentos e tratamentos que recusa à equipe de saúde de seu médico de confiança e na manifestação de consciência de seu ato.

É fundamental que o declarante expresse no documento que foi esclarecido sobre a possibilidade de revogação do documento a qualquer momento, sem a necessidade de justificativa. A declaração prévia de vontade para o fim da vida contém conteúdo volitivo e, pela sua própria natureza, pode sofrer alterações, razão pela qual não pode ser permanente.

Não obstante, existem situações em que a declaração prévia sofre limitações. Dadalto (2013) cita a hipótese de contrariedade ao que determina o ordenamento jurídico, situação em que o médico não deverá cumprir as determinações constantes no documento e o que se configura como contraindicado ao tratamento do paciente, pelo fato de remeter a procedimentos já superados para a medicina. O médico também poderá deixar de cumprir o que determina 
a declaração prévia por razões religiosas, morais ou éticas. Neste caso, deverá justificar sua recusa e encaminhar o paciente a outro profissional para que cumpra as disposições do documento. A recusa imotivada e injustificada não será aceita em hipótese alguma (Rodotà, 2007).

Aos cinco itens mencionados, sugerimos neste livro que seja incluída a necessidade de aconselhamento médico e jurídico, como pressupostos fundamentais para a validade do documento. Esse assunto, que será tratado mais amplamente adiante, reafirma a preocupação com o instituto. Entende-se que a participação de um médico é fundamental para esclarecer ao declarante no que consiste cada procedimento e tratamento disponível para ser utilizado em pacientes terminais, os benefícios e malefícios de sua utilização, e as consequências da decisão dele. De modo análogo, a participação de um advogado é essencial para o aconselhamento técnico-jurídico, ao esclarecer as implicações da decisão do declarante e informar a possibilidade de revogação do documento.

A declaração prévia de vontade para o fim da vida não apresenta uma forma determinada em países com estrutura jurídica análoga à brasileira. Não é imposta a forma pública ou privada. Contudo, recomenda-se a forma pública, pois o notário, ao lavrar a escritura, confere-lhe validade, em razão de sua fé pública. Ao ser feito o documento, é importante a participação de no mínimo duas testemunhas, para conferir validade ao ato. A lei espanhola criou o Registro Nacional de Instruções Prévias, subordinado ao Ministério da Saúde e Consumo (Lópes Sánchez, 2003), onde as declarações prévias são arquivadas e podem ser consultadas por meio eletrônico. No Brasil, entendemos que também deva ser criado um órgão público semelhante, subordinado ao Colégio Notarial (Dadalto, 2013), para que as declarações prévias possam ser arquivadas e consultadas.

A criação desse banco de declarações prévias confere efetividade ao instituto, evitando que o desejo do paciente se perca em meio à burocracia cotidiana. 
É importante que o documento seja anexado pela equipe médica junto ao prontuário do paciente, o que confirmará que ela sabia de sua existência e agiu em consonância com o desejo dele.

E em qual momento teria eficácia a declaração prévia para o fim da vida prevista no Brasil?

A lei norte-americana preceitua o prazo de quatorze dias a partir da formulação do documento para que ele tenha eficácia. O legislador acredita que esse prazo é suficiente para que o declarante reflita sobre sua decisão e, em caso de arrependimento, revogue-a antes que produza efeitos jurídicos. Já na Espanha a eficácia é imediata: as declarações podem ser revogadas no momento em que o outorgante desejar, não sendo previsto o prazo de arrependimento (Dadalto, 2013).

Contudo, acredita-se que a declaração prévia passa a ter eficácia no momento em que ela é anexada ao prontuário do paciente. Nesse momento, não resta nenhuma dúvida de que a equipe médica sabe que existe a declaração, independentemente se a opção foi pela lavratura de uma escritura, pela forma pública, ou por meio de um instrumento particular, com a presença de, no mínimo, duas testemunhas. Nesse momento, a atuação da equipe de saúde passa a ser vinculada ao desejo do declarante.

Outra questão é se haveria prazo de validade para a declaração de vontade. A lei portuguesa adotou o prazo de validade de cinco anos, sob o argumento de que o declarante poderia esquecer de ter elaborado o documento. Além disso, os procedimentos, os tratamentos e as técnicas médicas encontram-se em constante evolução, surgem novas terapias que permitem a cura de doenças até então desconhecidas, o que faz que muitas vezes a declaração se torne obsoleta (López Sánchez, 2003).

Entretanto, deve-se ressaltar que a declaração prévia para o fim da vida só é utilizada como fator inibidor para a prática da distanásia. A partir do momento em que surge uma nova técnica que permite a cura de uma doença desconhecida no momento da elaboração do documento, a declaração perde sua validade, pois deixa 
de tutelar uma situação de terminalidade e irreversibilidade da enfermidade e, portanto, passa a contrariar o ordenamento jurídico, o que é vedado.

Como a declaração prévia pode ser revogada a qualquer momento e a descoberta de nova técnica que torne possível a cura de uma doença elencada no documento faz que ele perca sua validade e o torne nulo, por contrariar a legislação vigente, considera-se desnecessária a imposição de prazo de validade para ele.

No que se refere à denominação da declaração, a doutrina estrangeira comumente utiliza as expressões living will, patientenverfügungen, testamento biológico, advance directives, voluntad antecipada, instrucciones previas e directivas antecipadas de vontade. No Brasil, a expressão mais utilizada é testamento vital (Furtado, 2014).

Essa expressão, apesar de bastante utilizada, gera equívocos, pois permite uma associação natural com o testamento sucessório, com disposições sobretudo patrimoniais e sempre post mortem, o qual em nada se assemelha às declarações prévias para o fim da vida.

Acredita-se que o instituto tenha recebido o nome de testamento vital em razão de uma tradução literal e equivocada da expressão living will, do direito saxão. O termo living traduz-se como "vida". O termo will pode ser traduzido como "testamento", mas também como "anseio, vontade". Portanto, a tradução literal permite a nomenclatura "testamento vital", mas também permite entender que o real objetivo do instituto é demonstrar as vontades referentes à vida, ou ainda a declaração de vontades para o fim da vida.

É fundamental distinguir testamento e declaração prévia para o fim da vida. O testamento é um negócio jurídico personalíssimo, unilateral, solene, revogável, com disposições patrimoniais e extrapatrimoniais e que produz efeitos post mortem (Pereira, 2004). A declaração prévia também é um negócio jurídico personalíssimo e unilateral, uma declaração de vontade revogável e com conteúdo extrapatrimonial, contudo não apresenta solenidade e, principalmente, não produz efeitos post mortem (Dadalto, 2013). 
Essa é a razão pela qual se prefere a nomenclatura declaração prévia para o fim da vida, em lugar do termo testamento vital, pois mostra-se mais adequada à natureza do instituto, que é respeitar o desejo do declarante para a fase derradeira de sua vida, e não qualquer disposição com eficácia somente após a sua morte.

\section{Mandato duradouro}

A segunda espécie de diretiva antecipada de vontade é o denominado mandato duradouro, ou poder duradouro do representante. Assim como a declaração prévia para o fim da vida, esse instituto tem origem no direito norte-americano, no denominado durable power of attorney for health care. Na Espanha recebe o nome de mandato de asistencia sanitaria e poder para el cuidado de salud, em Portugal é chamado de procuradores de cuidados de saúde.

Enquanto a declaração prévia estabelece condutas que devem ou não ser tomadas no final da vida, o mandato duradouro consiste na outorga de procuração referente aos cuidados com a saúde, portanto com poder duradouro, em que se nomeia um representante para tomar as providências cabíveis em nome do paciente não apenas em situações de terminalidade (Naves; Sá, 2002).

Por meio do mandato duradouro, podem ser nomeados um ou mais procuradores para auxiliar os médicos na decisão de aceitar ou recusar um tratamento, em nome do mandante, se este estiver incapacitado para manifestar seu desejo. A decisão deverá sempre ser alicerçada nos valores e nos desejos dele (Dadalto, 2013).

O mandatário deverá conhecer intimamente o mandante, suas vontades e seus valores, e fazer que sejam respeitados. O outorgado apenas deverá cumprir a vontade do outorgante, estando a ela vinculado, omitindo seus valores e desejos (Marino, 2007).

Quem seria o procurador mais adequado? Ascendentes, descendentes, cônjuge, o médico de confiança do representado, o advogado da família ou até mesmo um familiar com grau de parentesco mais distante, pois é nessa escolha que repousa a grande dificuldade de efetividade do instrumento. 
O escolhido deve possuir grande afinidade com o representado, conhecê-lo profundamente, gozar da sua confiança. Caso não o conheça, ou mesmo que o conheça e não cumpra a sua vontade, o instituto perderá sua efetividade (Pereira, 2004).

Surgem dois obstáculos para a escolha de um procurador que desconhece o desejo do mandante: ou ele se recusa a cumprir a determinação do mandante por convicções próprias, por valores morais e religiosos diferentes dos dele, ou por apego e afeto ao mandante, não aceitando a irreversibilidade de sua condição.

É fundamental que sempre seja atendido o interesse do paciente. Mesmo diante das dificuldades apontadas, e ainda que os laços de afetividade sugiram que a vontade do mandante não deva ser cumprida, o procurador deve fazer que a vontade dele seja respeitada. O mandatário é apenas a voz do mandante que, por algum motivo, não pode mais ecoar. Sendo assim, se necessário, se o representante agir contrariamente à vontade do mandante, suas decisões poderão ser invalidadas (Beauchamp; Childress, 2002).

O mandato duradouro apresenta algumas vantagens, em razão de sua flexibilidade. Ele tem aplicação mais próxima em termos de tempo, havendo maior adequação entre a disposição de vontade e o estágio de desenvolvimento técnico-científico da medicina. Ainda, há a garantiade de que a deliberação do mandante será cumprida e adequação às novas realidades, visto que o procurador, em caso de omissão, decidirá com base nos valores do outorgante, fazendo os fatos concretos refletirem as vontades dele (Mulholland, 2014).

Esse instituto não se restringe à fase terminal. Pode ser utilizado sempre que o declarante se encontre incapacitado para manifestar sua vontade. Contudo, a nomeação de um procurador é fundamental mesmo quando é feita uma declaração prévia para o fim da vida, pois o documento pode apresentar inadequações ou ambiguidades.

Nesse caso, será importante buscar atender a intenção real do declarante. Uma pessoa que conheça o emitente e tenha afeto por ele deverá exercer a função de mandatário e auxiliar no cumprimento da declaração. 


\section{As diretivas antecipadas de vontade como dissentimento: uma modalidade especial de consentimento livre e esclarecido}

O consentimento livre e esclarecido é fundamental para garantir a autonomia do paciente, sua liberdade, o respeito a ele enquanto ser humano, preservando sua dignidade. Destina-se a informar e esclarecer o paciente, permitindo-lhe decidir se acusa ou rejeita um tratamento ou cuidado médico-hospitalar.

As diretivas de vontade devem ser entendidas como um modelo especial de consentimento livre e esclarecido, pois constituem um documento em que, previamente, diversos cuidados e tratamentos médicos são recusados, após amplo e efetivo esclarecimento feito por profissionais das ciências médica e jurídica.

Desse modo, é possível afirmar que há um dissentimento livre e esclarecido, pois o outorgante, após receber todas as informações disponíveis sobre os tratamentos e cuidados médicos existentes e acessíveis, além de ter todas as suas dúvidas esclarecidas, usando de sua liberdade e autonomia poderá recusar tratamentos e cuidados que não deseja receber no futuro, na hipótese de padecer de doença crônica, irreversível, incurável e em estágio terminal, de estar inconsciente e não puder manifestar seu desejo.

É inegável que a diretiva antecipada de vontade versa sobre uma recusa livre e esclarecida ao exercício da autonomia e da autodeterminação, baseada nos direitos da personalidade e na dignidade humana. Contudo, não segue o padrão do consentimento livre e esclarecido, o qual, em regra, existe para manifestar a adesão a um tratamento ou cuidado médico-hospitalar. Nela, ao contrário, documenta-se o dissentimento.

Isso não significa que não possa ser tratada como uma espécie ou modalidade especial de consentimento livre e esclarecido, ou dissentimento livre e esclarecido, como se propõe.

Ademais, as diretivas antecipadas de vontade são mais amplas, pois não se restringem às declarações prévias para o final da vida e ao dissentimento livre e esclarecido, mas vão além. Por meio do 
mandato duradouro, é nomeado um representante para substituir o mandante e cumprir seus desejos, caso seja necessário, mesmo que não esteja em situação de terminalidade, mas incapacitado para manifestar sua vontade. Trata-se de modalidade especial, com características próprias, mas com o mesmo objetivo: respeitar a autonomia e a autodeterminação do paciente. Afinal, quando o interessado em geral não formaliza sua renúncia a um tratamento, somente o recusa e o abandona. Quando há adesão ao tratamento ou cuidado, a aceitação costuma ser formalizada.

Esse instrumento oferece nova oportunidade de manifestação da vontade do paciente, respeitando seus valores, suas crenças e seus desejos, reconhecendo-o como um ser humano, com as suas convicções e escolhas. Configura-se como um verdadeiro termo de dissentimento ou recusa livre e esclarecido, que pode ser considerado uma espécie do gênero consentimento livre e esclarecido.

\section{Os avanços do Judiciário sobre a questão: análise do Enunciado n. 37 da I Jornada de Direito da Saúde do Conselho Nacional de Justiça}

O Conselho Nacional de Justiça (CNJ) promoveu, na cidade de São Paulo, nos dias 14 e 15 de maio de 2014, a I Jornada de Direito da Saúde. O evento aprovou diversos enunciados sobre questões referentes à saúde, dentre eles, o Enunciado n. 37, que estabelece:

As diretivas ou declarações antecipadas de vontade, que especificam os tratamentos médicos a que o declarante deseja ou não se submeter quando incapacitado de expressar-se autonomamente, devem ser feitas preferencialmente por escrito, por instrumento particular, com duas testemunhas, ou público, sem prejuízo de outras formas inequívocas de manifestação admitidas em direito.

O enunciado merece elogios por diversos motivos, sobretudo em razão da exigência de no mínimo duas testemunhas para 
a elaboração da diretiva antecipada de vontade feita por meio de instrumento particular, conferindo maior segurança jurídica ao declarante e ao responsável pelo seu cumprimento. Não existe a mesma exigência quando há opção pela forma pública, visto que o notário goza de fé pública.

No entanto, o enunciado recém-aprovado cometeu diversos equívocos conceituais (Dadalto, 2013). Primeiramente, pode-se mencionar o equívoco na utilização dos termos "diretivas antecipadas de vontade" e "declarações antecipadas de vontade" como sinônimos. Declarações antecipadas de vontade não existem. O que existe é a diretiva antecipada de vontade e a declaração prévia para o fim da vida, porém trata-se de institutos distintos. A primeira é gênero, e a segunda, sua espécie.

A confusão não se restringe à nomenclatura. Abrange também o alcance do instituto, que, pelo texto do enunciado, fica restrito a tratamentos médicos, quando na realidade abarca também cuidados médicos.

Nota-se uma maior preocupação do Judiciário com o tema. Embora não o tenha regulamentado, manifestou interesse ao elaborar o enunciado versando sobre ele. Essa foi a primeira oportunidade de sedimentar de modo correto a terminologia a ser adotada, mas ela foi desperdiçada.

\section{A importância do aconselhamento médico e jurídico nas diretivas antecipadas de vontade}

O advogado tem papel fundamental para a manutenção social, porque ele é o responsável por interpretar o ordenamento jurídico e, sempre que necessário, fazer que seja respeitado. Ele pode ser considerado a estrutura da sociedade (Martins, 1993).

Como defensor do ordenamento jurídico, o advogado colabora para a manutenção do Estado democrático de direito, uma vez que assegura ao cidadão comum que seus interesses serão tutelados por meio das normas vigentes. 
Quando há qualquer indício ou ameaça real de violação a um direito fundamental, para evitar a infração recorre-se ao advogado, ${ }^{5}$ profissional habilitado a desempenhar a tarefa de defesa dos interesses sociais, por meio de procedimentos judiciais. É ele que mobiliza o direito frente à injustiça (Pereira, 1975).

A profissão tem caráter público e político e sua atuação deve estar condicionada a valores éticos e morais. É a constante luta pela liberdade e pela justiça, que estão entre os maiores interesses sociais (Bomfim, 2014).

É inequívoco que o ordenamento jurídico é bastante complexo e hipertrofiado, em razão das suas inúmeras leis. Por essa razão, Vadel (2000) considera que o advogado desempenha a função de auxiliar o cidadão, prestando-lhe assessoria técnica no que diz respeito ao conteúdo e ao alcance das normas.

Assim, é inequívoca a importância da participação do advogado como assessor técnico na elaboração das diretivas antecipadas de vontade.

O ordenamento jurídico deve ser interpretado enquanto um sistema de regras. Ao analisar-se a legislação, é possível verificar que o Estatuto da Advocacia ${ }^{6}$ impõe a obrigatoriedade do visto do advogado para que atos e contratos constitutivos de pessoas jurídicas sejam admitidos para registro, sob pena de nulidade do instrumento. Entendimento semelhante tem a Lei do Registro de Comércio (Lei n. 8.934), que foi regulamentada pelo Decreto n. $1.800 / 96 .^{7}$

5 As menções feitas aos advogados são extensivas aos defensores públicos, que desempenham papel fundamental para a preservação dos interesses da população que não tem condições econômicas de financiar o patrocínio de seus interesses em juízo. $\mathrm{O}$ declarante menos favorecido poderá recorrer à defensoria pública, sem necessidade de pagamento.

6 Brasil. Lei n. 8.906, de 4 de julho de 1994. "Art. 1﹎-São atividades privativas de advocacia: $[\ldots] \oint 2^{\circ}$ Os atos e contratos constitutivos de pessoas jurídicas, sob pena de nulidade, só podem ser admitidos a registro, nos órgãos competentes, quando visados por advogados."

7 Brasil. Decreto n. 1.800, de 30 de janeiro de 1996. "Art. 36 - O ato constitutivo de sociedade mercantil e de cooperativa somente poderá ser arquivado se visado por advogado, com a indicação do nome e número de inscrição na respectiva Seccional da Ordem dos Advogados do Brasil." 
A exigência de visto de advogado se refere à constituição e alteração de atos constitutivos de qualquer pessoa jurídica, independentemente se por meio de instrumento público ou particular.

Essa exigência explica-se porque, em tese, o advogado é quem detém conhecimento técnico para elaborar um contrato, atendendo aos interesses individuais e sociais, agindo com fidelidade ao ordenamento jurídico, orientando e evitando prejuízos ao cidadão (Thomaz, 2008).

No mesmo sentido, a Lei n. 11.441/07, que dispõe sobre a realização de inventário, partilha, separação e divórcio consensual, por via administrativa, estabeleceu a obrigatoriedade de assessoria técnico-jurídica para a validade dos atos, por meio de procedimento extrajudicial, em que é adotada a forma pública.

A assistência jurídica não se resume à presença formal do advogado para autenticar o ato. Ele deve participar efetivamente, prestando orientação jurídica, esclarecendo dúvidas e elaborando a minuta que dará origem à escritura pública (Lôbo, 2014).

Diante disso, a estrutura normativa brasileira estabeleceu a obrigatoriedade da participação de um advogado para cumprir a função de oferecer assessoria efetiva em procedimentos como atos e contratos constitutivos de pessoas jurídicas, inventários, partilhas, separações e divórcios consensuais, por via administrativa. Por analogia, parece evidente que as diretivas antecipadas de vontade tutelam um bem jurídico de valor superior à constituição de pessoa jurídica, à disposição e sucessão patrimonial, à dissolução de sociedade matrimonial.

Desse modo, mostra-se imperioso regulamentar a participação obrigatória de um assessor jurídico para que as diretivas antecipadas de vontade tenham validade, considerando nulo o documento elaborado sem a participação e o aconselhamento de um advogado.

A função dele nas diretivas antecipadas é fundamental. Ele deverá atuar como um auxiliar, garantindo que os desejos do outorgante sejam respeitados, que a elaboração do documento cumpra os preceitos da legalidade, utilizando a melhor técnica, evitando ambiguidades e interpretações dúbias, que possam gerar dúvida à 
equipe médica no momento de concretizar suas disposições (Lippmann, 2013).

Ademais, o advogado auxiliará na escolha da melhor forma de elaboração do documento, no detalhamento de situações que poderão ocorrer, mostrará quais são as opções possíveis e os limites legais de cada uma delas, orientará na escolha do procurador de saúde, além de oferecer orientações jurídicas diversas, relativas, por exemplo, aos direitos subjetivos dos pacientes em terminalidade e à sucessão patrimonial.

O entendimento relativo à assessoria médica é semelhante ao jurídico. A função do médico na sociedade não se limita à atuação tecnobiológica, como muitos pensam. A sua atuação é interdisciplinar e multifacetada, pautada por valores éticos, morais, culturais, científicos, políticos, humanos, sociais e ecumênicos (Boff, 1999). O médico desempenha atividade fundamental para a sociedade. Mais do que curar, ele é responsável por cuidar. Não há profissional mais apto a prestar esclarecimentos sobre um tratamento do que esse profissional da saúde. Ele possui formação técnica que lhe permite esclarecer os benefícios, os malefícios e as consequências de cada procedimento biomédico.

Desse modo, a ausência de aconselhamento médico poderá levar o outorgante a decidir com base em falsas premissas, as quais, por falta de informação ou por informação equivocada, acredita que são verdadeiras. Como consequência, chegará a uma conclusão falsa, sem alcançar seu real objetivo, e sua vontade estará comprometida pelo vício do erro.

Apenas haverá autonomia quando o interessado dispuser de informações reais e completas acerca das alternativas que lhe são apresentadas. Se não receber todas as informações necessárias, haverá uma falsa liberdade de escolha.

Diante do exposto, consideramos que deve ser obrigatório o aconselhamento médico e jurídico na elaboração das diretivas antecipadas de vontade. A falta de assessoria jurídica ou médica deve ensejar a nulidade absoluta do instrumento, seja ele público ou particular. 


\section{Responsabilidades oriundas das diretivas antecipadas de vontade do paciente}

O médico, no seu ofício, não assume o compromisso de obter um resultado específico, não garante que o resultado pretendido será alcançado. Ele não se compromete em curar o paciente, mas em empregar as melhores técnicas disponíveis para que seja conseguido um resultado satisfatório.

O Código Civil e o Código de Defesa do Consumidor reconhecem que a responsabilidade dos profissionais da saúde, em regra, é subjetiva. É preciso que se comprove a existência de pelo menos um dos elementos que caracteriza a culpa: ou negligência, ou imprudência, ou imperícia.

Desse modo, a culpa deve ser analisada em sentido amplo. Mesmo em uma situação complexa, ela deve ser comprovada. Se a conduta for isenta de dolo, negligência, imprudência ou imperícia, não haverá responsabilização (Kfouri Neto, 2007).

Todavia, não está em discussão um ato de iatrogenia ${ }^{8}$ ou os desdobramentos da prática médica, mas sim as consequências do cumprimento ou do descumprimento da vontade do paciente manifestada nas diretivas antecipadas de vontade, o que tem caráter e efeitos diversos.

Atualmente, em razão da ausência de uma lei que reconheça e regulamente expressamente as diretivas antecipadas do paciente, qualquer que seja a conduta do profissional da saúde, não será suficiente para garantir sua segurança em relação à licitude de sua decisão.

8 "Iatrogenia é uma palavra que deriva do grego: o radical iatro ('iatrós') significa médico, remédio, medicina; geno ('gennáo'), aquele que gera, produz; e ' $I a$ ', uma qualidade. [...] o significado mais aceito é o de que iatrogenia consiste num resultado negativo da prática médica. [...] Sob esta óptica, os 'erros médicos', tais como os conhecemos no Código de Ética Médica (imperícia, imprudência e negligência), se enquadram na categoria de iatrogenias, no entendimento contemporâneo" (Tavares, 2007). 
Embora regras esparsas reconheçam o direito à autonomia $e$ autodeterminação do paciente, esse entendimento depende de um esforço interpretativo sistemático, o que nem sempre é feito pelos operadores da ciência jurídica, o que gera insegurança entre os profissionais da saúde com relação às diretivas antecipadas de vontade.

Ademais, a legislação atual, tal como está formulada, permite ao paciente manifestar sua autonomia, mas não é suficiente para vincular a atuação do médico. Como a atuação do profissional é discricionária, ele pode cumprir ou não as diretivas antecipadas. E quais seriam as consequências éticas e jurídicas dessa escolha? Discutiremos isso a seguir.

\section{Responsabilidade civil decorrente do acatamento da manifestação antecipada de vontade do paciente}

As diretivas antecipadas de vontade estão pautadas em práticas de ortotanásia, que consiste no exercício regular dos preceitos médicos. Contudo, é fundamental que a família do paciente concorde com a prática, pois a negativa dos parentes pode ensejar ação judicial contra o profissional. A comunhão de vontades traz segurança ao médico (Sá, 2005).

É fundamental ressaltar que, embora a ortotanásia não esteja tipificada como crime no Código Penal, foi apresentada proposta de alteração do art. 121 no Anteprojeto do Código Penal incluindo-a entre as hipóteses excludentes de ilicitude. A proposta sugeria a inserção do $\S 4^{\circ}$, que iria dispor:

§ 40 - Não constitui crime deixar de manter a vida de alguém por meio artificial, se previamente atestada por dois médicos a morte como iminente e inevitável, e desde que haja consentimento do paciente, ou na sua impossibilidade, de ascendente, descendente, cônjuge, companheiro ou irmão.

Ainda que a proposta de inclusão do § 4o ao art. 121 do Código Penal não tenha sido aceita, é suficiente para demonstrar que parte 
da doutrina considera que a prática de ortotanásia poderia configurar crime, tanto que almejava incluí-la como hipótese de exclusão de ilicitude.

Ademais, a conduta do médico pode ser interpretada como omissão voluntária, capaz de provocar a morte, configurando homicídio privilegiado por relevante valor moral e social, ${ }^{9}$ que dará inclusive ensejo à diminuição da pena que originou o crime, ou ainda omissão de socorro, ${ }^{10}$ ambos os crimes tipificados pelo Código Penal.

É imperioso ressaltar que o Código Penal não elenca, entre as causas capazes de afastar a ilicitude do ato, o pedido da vítima. Desse modo, o consentimento ou a solicitação do paciente são irrelevantes para afastar a caracterização do crime (Borges, 2007).

O entendimento majoritário, e aparentemente correto, é que a prática médica não deva ser punida, mas não há segurança quanto a essa questão. Ainda que o profissional não seja condenado, o simples fato de enfrentar o processo judicial já lhe causa inúmeros prejuízos, que vão desde arcar com os custos do processo até a repercussão profissional e familiar que o caso ganharia. A arte médica está baseada na confiança, e a simples averiguação de uma conduta ilícita de um profissional da saúde pode ser suficiente para destruir sua carreira profissional. Além disso, a repercussão do caso pode refletir na família do profissional, afetando pessoas que não têm envolvimento direto com ele, como cônjuge, filhos, pais e irmãos.

9 Brasil. Decreto-lei n. 2.848, de 7 de setembro de 1940. Código penal. "Art. 121 - Matar alguém: Pena - reclusão, de seis a vinte anos.

Caso de diminuição de pena: $\S 1$ 을 Se agente comete o crime impelido por motivo de relevante valor social ou moral, ou sob o domínio de violenta emoção, logo em seguida a injusta provocação da vítima, o juiz pode reduzir a pena de um sexto a um terço."

10 Decreto-lei n. 2.848. "Art. 135 - Deixar de prestar assistência, quando possível fazê-lo sem risco pessoal, à criança abandonada ou extraviada, ou à pessoa inválida ou ferida, ao desamparado ou em grave e iminente perigo; ou não pedir, nesses casos, o socorro da autoridade pública:

Pena - detenção, de um a seis meses, ou multa." 
Desse modo, havendo todos os indícios de ausência de ilicitude na conduta do profissional, não é seguro que o acatamento das diretivas antecipadas de vontade dê causa à responsabilização do profissional.

Não é lícito o médico alegar em sua defesa a existência da Resolução n. 1.805/2006 e da Resolução n. 1.995/2012, ambas do Conselho Federal de Medicina, pois nenhuma delas tem eficácia geral, restringindo-se aos profissionais vinculados ao conselho. Seu conteúdo está adstrito à postura ética profissional, não servindo como excludente de antijuridicidade ou de ilicitude, razão pela qual sua alegação em defesa do ato médico não será suficiente para afastar a responsabilização. O profissional estará isento apenas de sanções oriundas de infração ética. Apenas a regulamentação do instituto é capaz de conferir segurança jurídica para a equipe médica ao acatar o que está determinado nas diretivas antecipadas de vontade.

\section{Responsabilidade civil decorrente do não acatamento da manifestação antecipada de vontade do paciente}

Outra situação ainda mais complexa é o não acatamento das diretivas. Ao descumprir o que está registrado no documento e, em consequência, desrespeitar a autonomia do paciente, o médico pratica um ato ainda mais grave, a obstinação terapêutica, uma vez que intenta manter viva uma pessoa que já se encontra em processo irreversível de morte e todas as tentativas de cura são infrutíferas. Essa conduta gera consequências éticas e cíveis.

Reitere-se que o médico, ao empreender ações terapêuticas inúteis ou obstinadas, comete infração ética, conforme disposto no art. 41 do Código de Ética Médica. ${ }^{11}$ Ele tem o dever ético de respeitar

11 Conselho Federal de Medicina. Código de Ética Médica de 2009. Capítulo I, inciso XXII. "Art. 41 - Parágrafo único. Nos casos de doença incurável e terminal, deve o médico oferecer todos os cuidados paliativos disponíveis sem empreender ações diagnósticas ou terapêuticas inúteis ou obstinadas, levando sempre em consideração a vontade expressa do paciente ou, na sua impossibilidade, a de seu representante legal." 
a autonomia do paciente, desde que sua vontade não contrarie valores éticos e morais do profissional.

Praticar um procedimento ou tratamento que a ciência médica considera inútil terapeuticamente, além de não promover nenhum benefício para o paciente, poderá ampliar o seu sofrimento, pois há desproporcionalidade entre benefícios mínimos e transitórios. $\mathrm{O}$ médico, que é o responsável por decidir entre iniciar o tratamento ou reconhecer que é inútil, deverá ponderar antes de fazer a escolha, que deve estar pautada em critérios objetivos de cuidado, tendo dados seguros (Serrão, 1998). O médico que opta pelo tratamento inútil praticará uma infração ética. Além disso, o profissional que descumpre o texto da diretiva antecipada de vontade comete ainda um ilícito jurídico que implicará a reparação do dano por meio da responsabilidade civil.

Para que seja configurada e aplicada a responsabilidade civil, é necessária a existência de seus elementos constitutivos. Deve haver uma conduta (na hipótese aventada, a obstinação terapêutica) em contrariedade à autodeterminação do paciente; um dano material ou moral; e nexo causal, responsável por fundir a conduta ao dano, demonstrando que este ocorreu em razão da conduta (Stoco, 2004).

Some-se a todos esses elementos a necessidade de comprovar a vontade na conduta do agente, representada pela culpa em sentido amplo (negligência, imprudência, imperícia ou dolo).

O médico que descumpre intencionalmente as diretivas antecipadas pratica uma conduta dolosa.

A responsabilidade civil pode ocorrer devido a um dano patrimonial, em consequência de prejuízo material, por ser atingido qualquer bem que possa ser representado de modo pecuniário, ou a um dano moral, decorrente de uma dor ou um sofrimento psicológico que atinge valores íntimos do indivíduo, os quais não são expressos monetariamente. Deve-se analisar a possibilidade de o descumprimento ensejar um dano moral ao paciente e seus familiares, devido à angústia, à dor e ao sofrimento provocados nessas pessoas em consequência da prática da distanásia. O dano moral pode ser entendido como a emoção, a dor, o espanto, a vergonha, 
a aflição moral ou física, ou seja, um sofrimento suportado pelo indivíduo em razão da conduta de outrem. O vocábulo "dor" deve ser interpretado de modo amplo, abarcando diversos significados (Minozzi, 1917).

É inegável que o prolongamento inútil da vida, devido à obstinação terapêutica, contrariando o desejo do paciente e de seus familiares, causará abalo psicológico, que configura o dano moral.

O dano moral pode ser definido como uma lesão cometida por alguém aos sentimentos de outrem. Para o lesado, essa conduta terá como consequência a dor e o sofrimento, que podem ser psíquicos ou físicos, a inquietação espiritual, dificuldades de relacionamento, ou seja, todas as lesões que não sejam suscetíveis de valoração pecuniária (Alsina, 1993).

Não há dúvidas de que o não acatamento das diretivas antecipadas de vontade enseja dor e sofrimento. Ainda que o paciente esteja incapacitado para manifestar sua contrariedade, os familiares acompanharão o seu sofrimento, em razão de um procedimento ou tratamento que havia recusado. A equipe médica, com sua conduta, será a responsável pelo dano e deverá ser responsabilizada pelo sofrimento moral ao qual o paciente e seus familiares foram expostos.

Ainda restará a responsabilidade patrimonial, pois o prolongamento do processo de morte gera custos. As terapias para pacientes terminais, em razão do alto grau de tecnologia utilizada, têm valores elevados, como também os honorários dos profissionais envolvidos, que têm direito a remuneração pela sua atuação.

Se o enfermo estiver internado em um hospital particular, ele próprio deverá arcar com o pagamento do tratamento, ou os seus familiares ou amigos. Se o paciente for titular de um plano de assistência médico-hospitalar, o convênio médico será o responsável pelo pagamento dos procedimentos. Se o tratamento do paciente for realizado no sistema público de saúde, a coletividade, representada pelo erário, será responsável pelo pagamento.

Nesse caso, em que é gerado prejuízo devido à conduta médica, a equipe deverá ser responsabilizada. Deve-se ressaltar que o termo "dano" remete ao resultado de qualquer espécie de lesão, 
seja patrimonial, moral, religiosa, política ou de qualquer outra natureza. Contudo, juridicamente, o seu significado restringe-se ao conteúdo moral e patrimonial. O dano patrimonial é representado pela redução do patrimônio de uma pessoa em razão de um ato que lhe causou prejuízo material (Azevedo, 1998).

Diante do exposto, é possível afirmar que o descumprimento da diretiva antecipada de vontade por parte do médico provoca a redução do patrimônio do responsável pelo pagamento dos tratamentos médico-hospitalares e, portanto, prejuízo, e ele deve responder juridicamente pela sua conduta.

Portanto, um único ato pode ocasionar três modalidades de infrações: ética, moral e patrimonial, ou material, todas passíveis de sanções, o que mostra a importância do respeito à autonomia e à autodeterminação do paciente, representadas nas diretivas antecipadas de vontade.

Fica latente a insegurança dos profissionais da saúde, em termos jurídicos, por causa da falta de regulamentação das diretivas antecipadas. Afinal, seja qual for a conduta do profissional, de acatamento ou não acatamento das disposições, ele estará sujeito a implicações jurídicas.

Apesar da grande relevância médica e jurídica do tema, os legisladores ainda não demonstraram conhecer a realidade a que os profissionais envolvidos com pacientes terminais estão expostos todos os dias. Assim, urge a sua regulamentação. 


\section{Considerações finaIS}

Este livro abordou as questões essenciais referentes às diretivas antecipadas de vontade, fazendo uma análise sob a perspectiva da bioética e do direito.

Inicialmente, buscou-se demonstrar que a bioética, responsável por estabelecer limites éticos às ciências da vida e às interações sociais e científicas que têm pessoas como sujeitos ou influenciam diretamente a vida humana, em razão de sua natureza interdisciplinar, apresenta uma interface com a ciência jurídica.

O direito, responsável por regular as relações humanas, estabelecendo os limites da conduta de cada indivíduo e sanções no caso de descumprimento das leis, também guarda estreita relação com as questões bioéticas, o que fez surgir um novo ramo da ciência jurídica, denominado biodireito, responsável por regulamentar essa interação.

Como toda ciência, a bioética tem os próprios princípios norteadores, que servem como orientação para todas as condutas. Foram abordados no livro os quatro princípios descritos no Belmont Report, também denominado principialismo bioético, sob influência norte-americana, e os princípios de origem europeia, descritos na Declaração Universal sobre Bioética e Direitos Humanos.

Além dos princípios da autonomia, beneficência, justiça e não maleficência, que compõem o principialismo, destacam-se os prin- 
cípios da responsabilidade individual; incapacidade para consentir; respeito pela vulnerabilidade humana e pela integridade individual, privacidade e confidencialidade; não discriminação e não estigmatização; respeito pela diversidade cultural e pelo pluralismo; solidariedade humana e cooperação internacional; responsabilidade social e promoção da saúde; compartilhamento de benefícios; proteção das gerações futuras; proteção do meio ambiente, da biosfera e da biodiversidade, todos oriundos da Declaração Universal sobre Bioética e Direitos Humanos.

Mereceu consideração especial a dignidade da pessoa humana, princípio que tem origem constitucional e compõe o núcleo axiológico do ordenamento jurídico, uma vez que não há como tutelar qualquer direito subjetivo sem a dignidade humana.

A comunhão de todos esses princípios constitui o embasamento protetivo do indivíduo que pretende adotar a diretiva antecipada de vontade, mas eles não são os únicos.

Toda manifestação de vontade depende de um exercício de autonomia, a qual se concretiza quando o sujeito pode escolher livremente uma entre as alternativas que lhe são oferecidas. Para que ocorra efetivamente o exercício da autonomia, é fundamental que ele conheça amplamente as alternativas, que não exista qualquer dúvida ou incerteza. Se houver, a sua liberdade de escolha estará viciada, pois o alcance da sua escolha será parcialmente desconhecido.

A natureza humana impõe que seja eleita a opção que lhe é mais benéfica, que traz resultados positivos. Todavia, nem sempre as alternativas disponíveis apresentam conteúdo positivo. Por vezes, problemas éticos requerem que sejam feitas escolhas práticas de modo prudente e ponderado, sendo impossível alcançar a solução ideal. Muitas vezes, em situações de terminalidade, em que se defrontam qualidade e prolongamento da vida, deve-se agir com ponderação, fazendo uso da deliberação moral.

Todos esses temas estão diretamente relacionados aos direitos da personalidade, com embasamento constitucional e infraconstitucional, sob influência dos direitos humanos. 
Buscou-se demonstrar, neste livro, que a autonomia e a autodeterminação do paciente, expressas nas diretivas antecipadas de vontade, compõem o arcabouço jurídico dos direitos da personalidade e devem ser reconhecidas em todas as fases da vida, ainda que sua opção seja pelo não prolongamento do processo de morte.

A busca pelo prolongamento da vida é inerente ao ser humano, em especial quando qualidade e quantidade de vida estão associadas, o que nem sempre é possível. Muitas vezes, existe quantidade de vida, mas sem qualidade, porque acompanhada de sofrimento, dores e angústias. Nesse caso, prolongá-la perde o sentido, e o que se deve buscar não é ampliar a quantidade de dias vividos, mas a diminuição do sofrimento, com o restabelecimento da dignidade.

A incessante evolução biotecnocientífica fez que o antigo paradigma de que há vida enquanto o coração pulsa tenha deixado de corresponder à realidade, pois a tecnologia possibilita que o coração ainda pulse de modo mecânico em um corpo desanimado, provocando apenas ampliação da angústia do paciente e de seus entes queridos.

Muitas vezes, o paciente sobrevive graças a procedimentos médico-hospitalares, mas já não possui vida. Ocorre o prolongamento do processo de morte, mas não da quantidade de vida, dos dias de vida.

A morte deve ser encarada apenas como a fase final da vida, e não como um mal. Ela faz parte da vida humana, e merece ser respeitada. Nessa fase também a dignidade deve ser preservada, por meio de uma terapia humanizada do paciente terminal que tenha como fim tratá-lo, já que, muitas vezes, a cura não pode mais ser alcançada. A morte digna é mais um dos componentes da vida digna e, em consequência, da dignidade humana.

Abordamos no livro as espécies de intervenções médicas em pacientes terminais: a eutanásia, a distanásia, a ortotanásia. O Conselho Federal de Medicina prescreve a prática de ortotanásia, condenando eticamente a eutanásia e a distanásia. Na ortotanásia, há a tutela da morte digna, sem prolongar o tempo de vida à custa da ampliação do sofrimento do paciente, mas também sem antecipar sua morte, preservando a sua dignidade nessa fase final da vida. Nossa posição é que seja adotado esse tipo de intervenção. 
Entende-se que a preservação da autonomia do paciente está associada à sua manifestação de vontade de modo livre e previamente esclarecido. Nesse contexto, o termo de consentimento livre e esclarecido ganha especial importância, pois é o instrumento que materializa o recebimento de informações sobre os procedimentos, cuidados e tratamentos, com seus benefícios e riscos, permitindo ao interessado aderir ou não a eles.

A manifestação de vontade do paciente de aderir a um tratamento é fundamental para a tutela dos direitos da personalidade e da dignidade da pessoa humana. Diversos diplomas legais e deontológicos, em todo o mundo, prescrevem sua obrigatoriedade antes de qualquer procedimento médico-hospitalar.

Somente o conhecimento prévio das consequências de qualquer conduta médica é capaz de evitar abusos ou condutas tidas como inapropriadas. Afinal, ninguém é obrigado a submeter-se a procedimento contra a sua vontade, salvo por determinação legal.

As diretivas antecipadas de vontade são o meio pelo qual o outorgante previamente renuncia a cuidados extraordinários, na hipótese de padecer de doença incurável, irreversível e encontrar-se em fase terminal, requerendo que sejam mantidos apenas os cuidados paliativos, que aliviem seu sofrimento e restabeleçam sua dignidade, se, futuramente, estiver incapacitado para manifestar sua vontade. Por meio desse documento, o paciente recusa a prática da distanásia e pleiteia a da ortotanásia.

Em razão de suas características, as diretivas antecipadas de vontade podem ser consideradas uma modalidade especial de consentimento livre e esclarecido, mais especificamente, um documento de dissentimento livre e esclarecido por meio do qual o paciente, por antecipação, manifesta sua não adesão a tratamentos futuros, vinculando a atuação do médico ao desejo do outorgante.

O documento representa o reconhecimento dos direitos do paciente à autonomia e à autodeterminação, bem como constitui um modo de assegurar que a relação médico-paciente permaneça saudável, mesmo no fim da vida e diante da incapacidade de manifestação de vontade do enfermo. 
No livro foram analisadas as principais legislações sobre o tema, com especial atenção para a lei dos Estados Unidos, país que criou o instituto; da Espanha, principal representante europeu; e da Argentina, país latino-americano com maior produção sobre o tema.

Para a validade das diretivas antecipadas de vontade, nossa proposta é a obrigatoriedade de participação de assessoria jurídica e médica, devido à necessidade de oferecer informações claras e amplas sobre o conteúdo técnico da decisão e as consequências de sua manifestação.

A interpretação sistemática da legislação brasileira demonstra que, em situações nas quais bens de menor valor jurídico são tutelados, é obrigatória a participação de um assessor jurídico para conferir eficácia ao ato. Sendo assim, pugna-se pela participação de um assessor jurídico na elaboração das diretivas.

Analogamente, entende-se que a participação de um médico também é fundamental para a validade do documento, acompanhando o disposto na legislação italiana. Afinal, só há exercício de autonomia e de autodeterminação quando o declarante conhece de modo integral o conteúdo e as consequências de suas escolhas, e não há como tomar uma decisão de modo esclarecido sem assessoria técnica.

Por derradeiro, buscou-se demonstrar a necessidade de regulamentação do instituto que, embora já seja utilizado, ainda não dispõe de normatização específica.

A atual estrutura normativa gera insegurança jurídica para os profissionais da saúde que prestam serviços a pacientes terminais que tenham manifestado sua vontade por meio de uma diretiva antecipada de vontade. Essa insegurança existe porque, independentemente da sua conduta, o médico estará sujeito a punição, seja na esfera ética, civil ou penal. A única maneira de conferir segurança à equipe médica é a normatização específica do instituto. Embora a interpretação de leis esparsas do ordenamento jurídico permita a adoção das diretivas antecipadas de vontade, sua fundamentação conceitual e prática ainda necessita ser disposta de modo claro e definitivo. 


\section{REFERÊNCIAS BIBLIOGRÁFICAS}

ADEODATO, J. M. Bases para uma metodologia da pesquisa em direito. Revista do Centro de Estudos Judiciários, Brasília, DF, ano 3, v.7, p.14350, 1999.

ALEXY, R. Teoria dos direitos fundamentais. Tradução de Virgílio Afonso da Silva. São Paulo: Malheiros, 2008.

ALMEIDA, A. J. T. de. A ortotanásia e a lacuna legislativa. In: AZEVEDO, A. V.; LIGIERA, W. R. (Coords.). Direitos do paciente. São Paulo: Saraiva, 2012.

ALSINA, J. B. Teoria general de la responsabilidad civil. Buenos Aires: Abeledo-Perrot, 1993.

ALVARENGA, M. A. de F. P. A responsabilidade civil em face do abandono afetivo e a problemática do quantum indenizatório. Revista Eletrônica da Faculdade de Direito de Franca, v.5, n.1, p.234-49, jul. 2012. Disponível em: <www.revista.direitofranca.br/index.php/refdf/article/download/165/113>. Acesso em: 16 jul. 2014.

ALVES, C. A.; FERNANDES, M. S.; GOLDIM, J. R. Diretivas antecipadas de vontade: um novo desafio para a relação médico-paciente. Revista HCPA, Porto Alegre, v.32, n.3, p.358-62, 2012. Disponível em: <http://seer.ufrgs.br/hcpa/article/view/33981/22041>. Acesso em: 17 jun. 2014.

AMARAL, F. Direito civil: introdução. 4.ed. Rio de Janeiro: Renovar, 2002. ANDERSON, M. The capacity to make a will when the testator's mental capacity is impaired; Catalan Supreme Court Judgement January 26, 
2009. Indret, Barcelona, v.3, p.1-15, jul. 2009. Disponível em: <http:// www.ssrn.com/abstract=1440242>. Acesso em: 27 maio 2014.

ARAUJO, L. E. D. O direito de morrer: o caso Eluana Englaro. Jus Navigandi, Teresina, ano 14, n.2.099, 31 mar. 2009. Disponível em: $<$ http://jus.com.br/artigos/12557>. Acesso em: 28 jun. 2014.

ARGENTINA. Ley n. 26.529 de 21 de octubre de 2009. Derechos del paciente en su relación con los profesionales e instituciones de la salud. Boletín Oficial, Buenos Aires, 20 nov. 2009. Disponível em: <http://www.infoleg.gov.ar/infolegInternet/anexos/160000-164999/160432/norma.htm>. Acesso em: 27 jun. 2014. . Ley n. 26.742, de 9 de mayo de 2012. Modifícase la Ley n. 26.529 que estableció los derechos del paciente en su relación con los profesionales e instituciones de la Salud. Boletín Oficial, Buenos Aires, 24 mayo 2012. Disponível em: <http://www.infoleg.gov.ar/infolegInternet/anexos/195000-199999/197859/norma.htm>. Acesso em: 27 jun. 2014.

ARNAUD, A.-J. Dicionário enciclopédico de teoria e sociologia do direito. Rio de Janeiro: Renovar, 1999.

ASCENSÃO, J. de O. A pessoa: entre o formalismo e a realidade ética. Revista da Emerj, Rio de Janeiro, v.9, n.33, p.93-115, 2006.

AZEVEDO, A. V. Curso de direito civil: teoria geral das obrigações. 7.ed. rev. e atual. São Paulo: Ed. Revista dos Tribunais, 1998.

AZEVEDO, M. A. O. de. Bioética fundamental. Porto Alegre: Tomo, 2002.

BARBOSA, H. F. Diretivas antecipadas de vontade: percepção de pacientes com diagnóstico de neoplasia maligna de ovário. Ribeirão Preto, 2011-2013. Disponível em: <http://www.bv.fapesp.br/pt/auxilios/31478/diretivas-antecipadas-de-vontade-percepcao-de-pacientes-com-diagnostico-de-neoplasia-maligna-de-ovar/>. Acesso em: 16 maio 2014.

É obrigatório o uso do termo de consentimento informado? Ribeirão Preto, [2014]. Disponível em: <http://www.hermesbarbosa.med.br/ noticias2.php?id=90>. Acesso em: 27 jun. 2014.

BARBOZA, H. H. Princípios da bioética e do biodireito. Revista Bioética, Brasília, DF, v.8, n.2, p.209-16, 2000. Disponível em: <http://www. portalmedico.org.br/revista/bio2v8/simpo1.pdf>. Acesso em: 19 maio 2014.

BARROSO, L. R. A dignidade da pessoa humana no direito constitucional contemporâneo: natureza jurídica, conteúdos mínimos e critérios de aplicação. Versão provisória para debate público, dez. 2010. (Mimeo.). 
Interpretação e aplicação da Constituição: fundamentos de uma dogmática constitucional transformadora. 5.ed. rev., atual. e ampl. São Paulo: Saraiva, 2003.

; MARTEL, L. de C. V. A morte como ela é: dignidade e autonomia individual no final da vida. In: BARBOZA, H. H.; MENEZES, R. A.; PEREIRA, T. da S. (Coords.). Vida, morte e dignidade humana. Rio de Janeiro: GZ, 2010.

BAUDOUIN, J.-L.; BLONDEAU, D. Éthique de la mort et droit à la mort. Paris: Press Universitaires de France, 1993.

BEAUCHAMP, T. L.; CHILDRESS, J. F. Principles of biomedical ethics. New York: Oxford University, 1979.

Princípios de ética biomédica. Tradução de Luciana Pudenzi. São Paulo: Loyola, 2002.

BÉLGICA. Déclaration anticipée de volonté. 28 maio 2002. Disponível em: <http:/ /www.bruxelles.be/artdet.cfm?id=5781\&\#a_1>. Acesso em: 28 jun. 2014.

BOBBIO, N. A era dos direitos. Rio de Janeiro: Campus, 1997.

Teoria geral do direito. Tradução de Denise Agostinetti. 2.ed. São Paulo: Martins Fontes, 2008.

BOFF, L. Saber cuidar: ética do humano - compaixão pela terra. Petrópolis: Vozes, 1999.

BOMFIM, B. C. A função social da advocacia. Disponível em: <www. neofito.com.br>. Acesso em: 19 jun. 2014.

BONAVIDES, P. Curso de direito constitucional. 21.ed. atual. São Paulo: Malheiros, 2007.

BORGES, R. C. B. Direitos de personalidade e autonomia privada. Coordenação de Renan Lotufo. 2.ed. São Paulo: Saraiva, 2007. (Prof. Agostinho Alvim).

Eutanásia, ortotanásia e distanásia: breves considerações a partir do biodireito brasileiro. Jus Navigandi, Teresina, ano 10, n.871, 21 nov. 2005. Disponível em: <http://jus.com.br/revista/texto/7571>. Acesso em: 31 mar. 2012.

BOSTIANCIC, M. C. Las directivas antecipadas del paciente para tratamentos biomédicos: validez ético-jurídica y responsabilidade civil de los profissionales de salud. Mar del Plata: Secretaria de Ciencia y Tecnica/ Ed. Universidad Nacional de Mar del Plata, 2008.

BRANDI, N. A. T. de; LLORENS, L. R. La creación del registro de actos de autoprotección. Revista Notarial de La Plata, v.948, p.41928, maio-ago. 2004. 
BRASIL. Constituição Federal da República Federativa do Brasil. Brasília, DF: Centro Gráfico do Senado, 1988.

. Decreto n.1.800, de 30 de janeiro de 1996. Regulamenta a Lei n. 8.934, de 18 de novembro de 1994, que dispõe sobre o Registro Público de Empresas Mercantis e Atividades Afins e dá outras providências. Diário Oficial da União, Poder Executivo, Brasília, DF, 31 jan. 1996. p.1.504. Disponível em: <http://www.planalto.gov.br/ ccivil_03/decreto/D1800.htm>. Acesso em: 20 jun. 2014.

Decreto-lei n. 2.848, de 7 de setembro de 1940. Código penal. Diário Oficial da União, Poder Executivo, Rio de Janeiro, 31 dez. 1940. p.2.391. Disponível em: <http://www.planalto.gov.br/ccivil_03/decreto-lei/Del2848.htm>. Acesso em: 27 jan. 2014.

. Lei n. 8.906, de 4 de julho de 1994. Dispõe sobre o Estatuto da Advocacia e a Ordem dos Advogados do Brasil (OAB). Diário Oficial da União, Poder Executivo, Brasília, DF, 5 jul. 1994. p.10.093. Disponível em: <http://www.planalto.gov.br/ccivil_03/leis/18906.htm>. Acesso em: 20 jun. 2014.

Lei n. 8.934, de 18 de novembro de 1994. Dispõe sobre o Registro Público de Empresas Mercantis e Atividades Afins e dá outras providências. Diário Oficial da União, Poder Executivo, Brasília, DF, 21 nov. 1994. p.17.514. Disponível em: <http://www.planalto.gov.br/ ccivil_03/leis/18934.htm>. Acesso em: 22 jun. 2014.

Lei n. 10.406, de 10 de janeiro de 2002. Institui o Código Civil. Diário Oficial da União, Poder Executivo, Brasília, DF, 11 jan. 2002. p.1. Disponível em: <http://www.planalto.gov.br/ccivil_03/ leis/2002/110406.htm>. Acesso em: 19 fev. 2014.

Lei n. 11.441, de 4 de janeiro de 2007. Altera dispositivos da Lei n. 5.869, de 11 de janeiro de 1973 - Código de Processo Civil, possibilitando a realização de inventário, partilha, separação consensual e divórcio consensual por via administrativa. Diário Oficial da União, Poder Executivo, Brasília, DF, 5 jan. 2007. p.1. Disponível em: <http://www.planalto.gov.br/ccivil_03/_ato2007-2010/2007/lei/ 111441.htm>. Acesso em: 17 jul. 2014.

Tribunal Regional Federal da 1ํㅡㄹ Região. Disponível em: <http:// portal.trf1.jus.br/portaltrf1/pagina-inicial.htm >. Acesso em: 2 abr. 2012.

CALLIOLI, E. C. Aspectos da fecundação artificial in vitro. Revista de Direito Civil, São Paulo, v.12, n.44, p.71-95, abr.-jun. 1988.

CALÒ, E. Il testamento biológico. Milano: Ipsoa, 2008. 
CANTERO MARTÍNEZ, J. La autonomia del paciente: del consentimiento informado al testamento vital. Albacete: Bomarzo, 2005.

CAPPELlETI, M. Juízes legisladores? Porto Alegre: Sergio A. Fabris, 1993.

CARDOSO, J. V. Ortotanásia: uma análise comparativa da legislação brasileira projetada e em vigor. 16 abr. 2012. Disponível em: <http:// www.egov.ufsc.br/portal/conteudo/ortotan\%C3\%A1 sia-uma-an\%C3\%A1lise-comparativa-da-legisla\%C3\%A7\%C3\%A3o-brasileira-projetada-e-em-vigor>. Acesso em: 19 mar. 2014.

CASADO, M.; ROYES, A. (Coords.). Documento sobre las voluntades anticipadas. Barcelona: Observatori di Bioètica i Dret, 2001.

CHAVES, A. Capacidade civil. In: FRANÇA, R. L. (Org.). Enciclopédia Saraiva de direito. São Paulo: Saraiva, 1977. v.13.

Direito à vida e ao próprio corpo: intersexualidade, transexualidade, transplantes. 2.ed. São Paulo: Ed. Revista de Tribunais, 1994.

CLOTET, J. Bioética, uma aproximação. Porto Alegre: EdiPUC-RS, 2003.

COMITATO NAZIONALE PER LA BIOETICA. Informazione e consenso all'atto medico. Roma, 1992.

COMPARATO, F. K. A afirmação histórica dos direitos humanos. 7.ed. rev. e atual. São Paulo: Saraiva, 2010.

CONSELHO FEDERAL DE MEDICINA. Código de Ética Médica de 2009. Diário Oficial da União, Brasília, DF, 24 set. 2009. Seção 1. p. 90. Disponível em: <http://www.portalmedico.org.br/novocodigo/integra.asp>. Acesso em: 1 abr. 2012.

Iniciação à bioética. Brasília, DF, 1998.

Resolução CFM n. 1.805/2006. Diário Oficial da União, Brasília, DF, 28 nov. 2006. Seção I. p.169. Disponível em: <http://www.portalmedico.org.br/resolucoes/cfm/2006/1805_2006.htm>. Acesso em: 2 abr. 2012.

Resolução CFM n. 1.995/2012. Dispõe sobre as diretivas antecipadas de vontade dos pacientes. Diário Oficial da União, Brasília, DF, 31 ago. 2012. Seção 1. p.269-70. Disponível em: <http://www.portalmedico.org.br/resolucoes/CFM/2012/1995_2012.pdf>. Acesso em: 2 out. 2012.

A ortotanásia na justiça brasileira. Revista Bioethikos, São Paulo, v.4, n.4, p.476-86, 2010. Disponível em: <http://www.saocamilo-sp. $\mathrm{br} / \mathrm{pdf} /$ bioethikos/80/Bioethikos_476-486_.pdf>. Acesso em: 8 jan. 2014. 
CONSELHO NACIONAL DE SAÚDE. Publicada Resolução 466 do CNS que trata de pesquisas em seres humanos e atualiza a Resolução 196. 14 jun. 2013. Disponível em: <http://conselho.saude.gov.br/ultimas_noticias/2013/06_jun_14_publicada_resolucao.htm>. Acesso em: 22 jul. 2014.

CORDEIRO, A. M. Tratado de direito civil português: parte geral. Coimbra: Almedina, 2007. t.3, v.1.

CRUZ, M. L. M. da; OLIVEIRA, R. A. de. A licitude civil da prática da ortotanásia por médico em respeito à vontade livre do paciente. Revista Bioética, Brasília, DF, v.21, n.3, p.405-11, 2013.

CUPIS, A. de. Os direitos da personalidade. Lisboa: Morais, 1961.

DADALTO, L. Capacidade versus discernimento: quem pode fazer as diretivas antecipadas de vontade In: . (Coord.) Diretivas antecipadas de vontade: ensaios sobre o direito à autodeterminação. Belo Horizonte: Letramento, 2013.

Testamento vital. 2.ed. Rio de Janeiro: Lumen Juris, 2013.

Declarações prévias de vontade em caso de terminalidade: estudos acerca da utilização do testamento vital como forma de prevenir demandas médicas e proteger a autonomia do paciente. In: DADALTO, L.; TEIXEIRA, A. C. B. (Orgs.). Dos hospitais aos tribunais. Belo Horizonte: Del Rey, 2013.

. Distorções acerca do testamento vital no Brasil (ou o porquê é necessário falar sobre uma declaração prévia de vontade do paciente terminal). Revista de Bioética y Derecho, Barcelona, n.28, p.61-71, maio 2013.

. Será a hora de jogar a toalha? Apontamentos sobre o enunciado $n$. 37 da I Jornada de Direito da Saúde do CNJ, 16 maio 2014. Disponível em: <http://diretivasantecipadas.blogspot.com.br/>. Acesso em: 19 jun. 2014.

D'ASSUMPÇÃO, E. A. Comportar-se fazendo bioética para quem se interesse pela ética. Rio de Janeiro: Vozes, 1998.

DIAS, R. O direito fundamental à morte digna: uma visão constitucional da eutanásia. Belo Horizonte: Fórum, 2012.

DINIZ, M. H. O estado atual do biodireito. 2.ed. São Paulo: Saraiva, 2002. DRUMOND, J. G. de F. Bioética clínica e direito médico. In: PESSINI, L.; BARCHIFONTAINE, C. de P. de (Orgs.). Bioética clínica e pluralismo. São Paulo: Centro Universitário São Camilo; Loyola, 2013.

DURKHEIN, E. O suicídio. Tradução de Monica Stahel. São Paulo: Martins Fontes, 2000. 
DWORKIN, R. Domínio da vida: aborto, eutanásia e liberdades individuais. 2.ed. São Paulo: WMF Martins Fontes, 2009.

El domínio de la vida. Barcelona: Ariel, 1998.

Taking rights seriously. Nova York: Bloomsbury Academic, 2013.

EMANUEL, E. J.; EMANUEL, L. L. Living wills: past, present, and future. The Journal of Clinical Ethics, Hagerstown, v.1, n.1, p.1-19, 1990.

ESPAÑA. Organización Médica Colegial. Código de Etica y Deontología Médica. Madrid, 10 set. 1999. Disponível em: < http://www.unav.es/ cdb/ccdomccedm1999.html>. Acesso em: 2 jun. 2014.

Ley n. 41, de 14 de noviembre de 2002. Boletín Oficial del Estado, Madrid, 14 nov. 2002, n.274, p.40.126-32. Disponível em: <http:// civil.udg.es/normacivil/estatal/persona/pf/L41-02.htm\#C4>. Acesso em: 23 jun. 2014.

Real Decreto n. 124/2007, de 2 de febrero de 2007. Boletín Oficial del Estado, Madrid, 15 fev. 2007, n.40, p.6.591-3. Disponível em: <http://www.boe.es/boe/dias/2007/02/15/pdfs/A06591-06593. pdf>. Acesso em: 24 jun. 2014.

FEDERAL COMMISSION ON PATIENTS' RIGHTS. Law Patients' Rights. 2007. Disponível em: <http://www.health.belgium.be/internet2Prd/groups/public/@public/@dg1/@legalmanagement/documdocu/ie2divers/19081113.pdf>. Acesso em: 29 jun. 2014.

FEDERAZIONE NAZIONALE DEGLI ORDINI DEI MEDICI CHIRURGHI E DEGLI ODONTOIATRI. Códice de Deontologia Medica. Roma, 1998. Disponível em: <http://www.unimi.it/cataloghi/comitato_etico/codice_deontologia_medica.pdf>. Acesso em: 27 jun. 2014.

FERNANDES, M. S. Bioética, medicina e direito de propriedade intelectual: relação entre patentes e células-tronco humanas. São Paulo: Saraiva, 2012.

FERRAZ JR., T. S. O corpo entre a vida e a morte. Folha de S.Paulo, 6 fev. 1997. Tendências/Debates, p.3.

FERREIRA, J. S. A. B. N. Bioética e biodireito. Scientia Iuris, Londrina, v.2-3, p.41-63, 1998-1999. Disponível em: <http://www.uel.br/ revistas/uel/index.php/iuris/article/view/11274>. Acesso em: 28 maio 2014.

FONSECA, R. T. M. da. O trabalho da pessoa com deficiência e a lapidação dos direitos humanos. São Paulo: LTr, 2006. 
FRANÇA, L. R. Institutos de proteção à personalidade. Revista dos Tribunais, São Paulo, ano 57, n.391, p.20-5, maio 1968.

FRANÇA, G. V. de. Eutanásia: um enfoque ético-político. Revista Bioética, Brasília, DF, v.7, n.1, p.113-20, 1999.

FURTADO, G. R. Considerações sobre o testamento vital. Civilistica. com, Rio de Janeiro, ano 2, n.2, p.4, 2003. Disponível em: <http:// civilistica.com/wp-content/uploads/2013/06/Gabriel-Rocha-Furtado-civ.a.2.n.2.2013.pdf>. Acesso em: 18 jun. 2014.

GAFO, J. 10 palavras-chave em bioética. Coimbra: Editorial Gráfica Coimbra, 1996.

GARCIA, I. A. Aspectos médicos e jurídicos da eutanásia. Revista Brasileira de Ciências Criminais, São Paulo, ano 15, n.67, p.253-75, jul.-ago. 2007.

GARCIA, M. A pessoa do paciente e a dignidade humana. In: AZEVEDO, A. V.; LIGIERA, W. R. (Coords.). Direitos do paciente. São Paulo: Saraiva, 2012.

GOLDIM, J. R. Caso Piergiorgio Welbi Eutanásia. Disponível em: $<$ http://www.bioetica.ufrgs.br/welby.htm>. Acesso em: 28 jun. 2014.

GRINBERG, M.; CHEHAIBAR, G. Z. Termo de consentimento com sentimento. In: AZEVEDO, A. V.; LIGIERA, W. R. (Coords.). Direitos do paciente. São Paulo: Saraiva, 2012.

GRACIA, D. Moral deliberation: the role of methodologies in clinical ethics. Medicine Health Care and Philosophy, Dordrecht, v.4, n.3, p.223-32, 2001.

HIRONAKA, G. M. F. N. Bioética e biodireito: revolução biotecnológica, perplexidade humana e prospectiva jurídica inquietante. Jus Navigandi, Teresina, ano 7, n.66, jun. 2003. Disponível em: <http:// jus2.uol.com.br/doutrina/texto.asp?id=4193>. Acesso em: 11 out. 2011.

HOSSNE , W. S.; VIEIRA, S. A experimentação com seres humanos: aspectos éticos. São Paulo: Edusp, 1995.

INSTITUTO NACIONAL DE CÂNCER. Cuidados paliativos. Disponível: <http://www.inca.gov.br/conteudo_view.asp?ID=474>. Acesso em: 17 jan. 2014.

ITÁLIA. Costituzione della Repubblica Italiana. Gazzetta Ufficiale, Roma, 27 dez. 1947, n.298. Disponível em: <http://www.quirinale. it/qrnw/statico/costituzione/pdf/Costituzione.pdf >. Acesso em: 27 jun. 2014. 
Legge, 28 marzo 2001, n.145. Gazzetta Ufficiale, Roma, n.95, 24 abr. 2001. Disponível em: <http://www.parlamento.it/parlam/ leggi/01145l.htm>. Acesso em: 18 abr. 2014.

JAHR, F. Bio=Ethik: Eine Umschau über die ethichen Beziehung des Menschen zu Tier und Pflanze. Kosmos, Sttugart, v.24, n.2, p.2-4, 1927.

JESUS, D. de. Código penal anotado. São Paulo: Saraiva, 2010.

JUNGES, J. R. A vida como bem fundamental do homem. Perspectivas teológicas. Belo Horizonte, v.25, n.67, p.339-45, 1993.

et al. Reflexões legais e éticas sobre o final da vida: uma discussão sobre a ortotanásia. Revista Bioética, Brasília, DF, v.18, n.2, p.275-88, 2010.

KANT, I. Fundamentação da metafísica dos costumes. Tradução de Paulo Quintela. Lisboa: Ed. 70, 1986.

KFOURI NETO, M. Responsabilidade civil do médico. 6.ed. rev., atual. e ampl. com novas especialidades: implantondontia, oftalmologia, ortopedia, otorrinolaringologia e psiquiatria. São Paulo: Ed. Revista dos Tribunais, 2007.

KOVÁCS, M. J. Autonomia e o direito de morrer com dignidade. Revista Bioética, Brasília, DF, v.6, n.1, p.61-9, 1998.

Bioética nas questões da vida e da morte. Psicologia USP, São Paulo, v.14, n.2, p.115-67, 2003.

KUTNER, L. Due process of euthanasia: the living will, a proposal. Indiana Law Journal, Bloomington, v.44, p.539-54, 1969.

LEÃO, T. P. V. Da (im)possibilidade do testamento vital no ordenamento jurídico brasileiro. Jus Navigandi, Teresina, ano 18, n.3.626, 5 jun. 2013. Disponível em: <http://jus.com.br/artigos/24638>. Acesso em: 23 jun. 2014.

LEITÃO, L. Acusada de mortes em UTI se apresenta no Fórum de Curitiba, mas juiz nega prisão. Veja Digital, São Paulo, 27 mar. 2013. Disponível em: <http://veja.abril.com.br/noticia/saude/ acusada-de-mortes-em-uti-se-apresenta-no-forum-de-curitiba-mas-juiz-nega-prisao>. Acesso em: 18 mar. 2014.

LEITE, E. de O. Da bioética ao biodireito: reflexões sobre a necessidade e emergência de uma legislação. In: SILVA, R. P. e (Org.). Direitos humanos como educação para a justiça. São Paulo: LTr, 1998.

LEMES, C. Direitos tornam-se lei. In: GOUVEIA, R. Saúde pública, suprema lei: a nova legislação para a conquista da saúde. São Paulo: Mandacaru, 2000. 
LIGIERA, W. R. Responsabilidade médica: diante da recusa de transfusão de sangue. São Paulo: Nelpa, 2009.

LIMA NETO, F. V. Direitos humanos de 4a geração. 20 abr. 1998. Disponível em: <http://www.dhnet.org.br>. Acesso em: 29 maio 2014.

LIPPMANN, E. O papel do advogado no testamento vital. In: DADALTO, L. (Coord.). Diretivas antecipadas de vontade: ensaios sobre o direito à autodeterminação. Belo Horizonte: Letramento, 2013.

LITTRÉ, E. Dictionnaire de médecine. 21.ed. Paris: Balliere, 1908.

LÔBO, P. Divórcio e separação consensuais extrajudiciais. Disponível em: $<$ http://www.cnj.jus.br/index.php?option=com_content\&view $=$ arti cle\&id=13313\&Itemid=675>. Acesso em: 20 jun. 2014.

LÓPEZ SÁNCHEZ, C. Testamento vital y voluntad del paciente: conforme a la Ley 41/2002, de 14 de noviembre. Madrid: Dykinson, 2003.

LUCREZI, F.; MANCUSO, F. Diritto e vita: biodiritto, bioetica, biopolitica. Soveria Mannelli: Rubbettino, 2010.

MALLET, E. O novo código civil e o direito do trabalho. Revista da Amatra II, São Paulo, v.4, n.8, p.22-9, 2003.

MALUF, F.; GARRAFA, V. O termo de consentimento livre e esclarecido nas pesquisas com seres humanos: um estudo de caso. Revista Bioética, Brasília, DF, v.19, n.3, p.725-39, 2011.

MARINO, I. R. M. Testamento biologico: i diritti dei malati e l'operato dei medici. In: BORASCHI, A.; MANCONI, L. (Coords.). Il dolore e la politica: accanimento terapeutico, testamento biologico, libertà di cura. Milano: Mondadori Bruno, 2007.

MARCHETTO, P. B. A importância da bioética e do biodireito na sociedade atual. Âmbito Jurídico, Rio Grande, n.69, 1 nov. 2010. Disponível em: <http://www.ambito-juridico.com.br/site/index.php?n_ link=revista_artigos_leitura\&artigo_id=6606>. Acesso em: 19 out. 2012.

MARKUS, K. The law of advance directives. Disponível em: <http:// www.scu.edu/ethics/publications/iie/v8n1/advancedirectives. html>. Acesso em: 23 jun. 2014.

MARREIRO, C. L. Responsabilidade civil do médico na prática da distanásia. Revista Bioética, Brasília, DF, v.21, n.2, p.308-17, 2013.

MARTIN, L. M. A ética diante do paciente terminal: leitura ético-teológica da relação médico-paciente terminal nos códigos brasileiros de ética médica. São Paulo: Santuário, 1993.

MARTINS, I. G. A função social do advogado. Revista do Advogado, São Paulo, v.5, n.14, p.94-99, jul.-set. 1983.

MASSIP, V. História da filosofia ocidental. São Paulo: EPU, 2001. 
MATIAS, A. G. M. A eutanásia e o direito à morte digna à luz da Constituição. Curitiba, 2004. 65f. Monografia (Graduação em Direito) Universidade Federal do Paraná.

MÉDICA ACUSADA de acelerar mortes na UTI se diz inocente. Fantástico. Rio de Janeiro: Globo, 9 jun. 2013. Programa de TV. Disponível em: <http://g1.globo.com/fantastico/noticia/2013/06/medica-acusada-de-acelerar-mortes-na-uti-se-diz-inocente.html>. Acesso em: 18 mar. 2014.

MENDES, G. F.; COELHO, I. M.; BRANCO, P. G. G. Curso de direito constitucional. São Paulo: Saraiva, 2010.

MINISTÉRIO DA SAÚDE. Portaria n. 1.820, de 13 de agosto de 2009. Dispõe sobre os direitos e deveres dos usuários da saúde. Diário Oficial da União, Brasília, DF, 14 ago. 2009. Seção 1, p.80-1. Disponível em: $<$ http://www.adj.org.br/download/pdf/portaria1820.pdf>. Acesso em: 23 jan. 2013.

MINOZZI, A. Studio sul danno non patrimoniale. 3.ed. Milano: Società Editrice Libraria, 1917.

MIRANDA, J. A Constituição portuguesa e a dignidade da pessoa humana. Revista de Direito Constitucional e Internacional, São Paulo, ano 11, n. 45, p.81-91, 2003.

MONTEIRO, W. de B. Curso de direito civil: parte geral. 38.ed. São Paulo: Saraiva, 2001.

MORAES, A. de. Direito constitucional. 4.ed. São Paulo: Atlas, 1998.

MOREIRA, M. S. Diretivas antecipadas de vontade: um estudo sobre o seu conteúdo lícito no Brasil. In: DADALTO, L. (Coord.). Diretivas antecipadas de vontade: ensaios sobre o direito à autodeterminação. Belo Horizonte: Letramento, 2013.

MORI, M. Nè buona nè cattiva, la natura è indifferente. MicroMega, Roma, 17 mar. 2009. Disponível em: <http://temi.repubblica.it/ micromegaonline/ ne-buona-ne-cattiva-la-natura-e-indifferente $>$. Acesso em: 27 jan. 2014

MULHOLLAND, K. C. Protecting the right to die: the patient self-determination act of 1990. Harvard Journal on Legislation, Cambridge, ano 28, n.2, p.609-30, 1991. Disponível em: <http://heinonline.org/>. Acesso em: 19 jun. 2014.

NALINI, J. R. Ética geral e profissional. 4.ed. São Paulo: Ed. Revista dos Tribunais, 2004.

NAMBA, E. T. Manual de bioética e biodireito. São Paulo: Atlas, 2009. 
NAVES, B. T. de O.; SÁ, M. de F. F. de. Da relação jurídica médicopaciente: dignidade da pessoa humana e autonomia privada. In: SÁ, M. de F. F. de (Org.). Biodireito. Belo Horizonte: Del Rey, 2002. v.1.

NEGRI, S. The right to informed consent at the convergence of the International Biolaw and International Human Rights Law. In:

(Org.). Self-determination, dignity and end-of-life care: regulating advance directives in international and comparative perspective. London: Martinus Nijhoff Publishers, 2012.

NERY JR., N. Direito de liberdade e consentimento informado: a possibilidade de se recusar tratamento médico em virtude de convicções religiosas. In: AZEVEDO, A. V.; LIGIERA, W. R. (Coords.). Direitos do paciente. São Paulo: Saraiva, 2012.

NEVES, M. do C. P. Contexto cultural e consentimento - uma perspectiva antropológica. In: GARRAFA, V.; PESSINI, L. (Orgs.). Bioética: poder e injustiça. São Paulo: Loyola/São Camilo, 2003.

NEVES, N. M. B. C.; SIQUEIRA, J. E. de. A bioética no atual Código de Ética Médica. Revista Bioética, Brasília, DF, v.18, n.2, p.439-50, 2010.

NOVELINO, M. Direito constitucional. 2.ed. São Paulo: Método, 2008.

NUNES, L. N. B. T. A pessoa natural e a relativização dos direitos da personalidade. In: BEÇAK, R.; VELASCO, I. M. P. (Orgs.). O direito e o futuro da pessoa: estudos em homenagem ao professor Antonio Junqueira de Azevedo. São Paulo: Atlas, 2011.

NUNES, R. Proposta sobre suspensão e abstenção de tratamento em doentes terminais. Revista Bioética, Brasília, DF, v.17, n.1, p.29-39, 2009.

OLIVEIRA, M. Z. P. B.; BARBAS, S. Autonomia do idoso e distanásia. Revista Bioética, Brasília, DF, v.21, n.2, p.328-37, 2013.

PACIFICI-MAZZONI, E. Istituzioni di diritto civile italiano. Firenze: E. e F. Cammelli, 1871.

PALMER, M. Problemas morais em medicina: curso prático. São Paulo: Loyola, 2002.

PARISE, P. S. O biodireito e a manipulação genética de embriões humanos. Goiânia: Kelps, 2003.

PENALVA, L. D. As contribuições da experiência estrangeira para o debate acerca da legitimidade do testamento vital no ordenamento jurídico brasileiro. In: CONGRESSO NACIONAL DO CONPEDI, 17, 2008, Brasília. Anais... Brasília, DF: Conpedi, 2008. p.516-38.

PEREIRA, A. G. D. O consentimento informado na relação médicopaciente. Coimbra: Coimbra, 2004. 
PEREIRA, C. M. da S. Instituições de direito civil. 15.ed. Rio de Janeiro: Forense, 2004. v.6.

. Problemas atuais da advocacia. Revista Forense, Rio de Janeiro, v.255, p.471-4, 1975.

PERLINGIERI, P. Perfis do direito civil: introdução ao direito civil constitucional. Rio de Janeiro: Renovar, 1997.

PESSINI, L. Eutanásia: por que abreviar a vida? São Paulo: Ed. Centro Universitário São Camilo, 2004.

Distanásia: até quando prolongar a vida. São Paulo: Loyola, 2001.

Dignidade humana nos limites da vida: reflexões éticas a partir do caso Terri Schiavo. Revista Bioética, Brasília, DF, v.13, n.2, p.65-76, 2005.

; BARCHIFONTAINE, C. de P. de. Problemas atuais de bioética. 5.ed. São Paulo: Ed. Centro Universitário São Camilo/Loyola, 2000.

PINTO, C. A. da M.; PINTO, P. M. Teoria geral do direito civil. 4.ed. Coimbra: Coimbra, 2005.

PINTO, C. da S. Quando o tratamento oncológico pode ser fútil? Do ponto de vista da paliativista. Revista Brasileira de Cancerologia, Rio de Janeiro, v. 54, n.4, p.393-6, 2008.

PIOVESAN, F. C. A proteção dos direitos humanos no sistema constitucional brasileiro. Revista da Procuradoria Geral do Estado de São Paulo, São Paulo, n.51-52, p.81-102, jan.-dez. 1999.

Direitos humanos e o princípio da dignidade humana. Revista do Advogado, São Paulo, v.23, n.70, p.34-42, jul. 2003.

PORTUGAL. Lei n. 25/2012 de 16 de julho de 2012. Diário da República, Porto, 16 jul. 2012. 1a Série, n.136, p.3.728. Disponível em: <http://dre.pt/pdf1s/2012/07/13600/0372803730.pdf>. Acesso em: 18 abr. 2014.

Regulamento n. 14/2009, de 26 de setembro de 2008. Diário da República, Porto, n.8, 2a Série, 11 jan. 2009. Disponível em: <https:// www.ensp.unl.pt/dispositivos-de-apoio/cdi/cdi/sector-de-publicacoes/revista/2000-2008/pdfs/rpsp-1-2009-1/08-2009.pdf>. Acesso em: 18 abr. 2014.

POSE, C. Lo bueno y lo mejor: introducción a la bioética médica. Madri: Triacastela, 2009.

POTTER, V. R. Bioethics: the science of survival. Perspectives in Biology and Medicine, Baltimore, v.14, n.1, p.127-53, 1970.

Bioethics: bridge to the future. Englewood Cliffs. New York: Prentice Hall, 1971. 
. O mundo da saúde, São Paulo, ano 22, v.22, n.6, p.370-4, 1998.

PULIDO, C. B. La racionalidad de la ponderación. In: CARBONELL, M. (Coord.). El principio de proporcionalidaddad y la protección de los derechos fundamentales. México: Comisión Nacional de los Derechos Humanos, 2008.

REALE, M. Introdução à filosofia. São Paulo: Saraiva, 1988.

REICH, W. T. (Org.). Encyclopedia of bioethics. New York: Simon \& Schuster: Mac Milan, 1978. v.1.

RIBEIRO, D. C. Suspensão de esforço terapêutico. Cadernos de Direito Clínico, Brasília, DF, ano 1, n.1, p.3-12, out. 2005.

Um novo testamento: testamentos vitais e diretivas antecipadas. In: CONGRESSO BRASILEIRO DE DIREITO DE FAMÍLIA, 5, 2006, São Paulo. Anais... São Paulo: IOB Thomson, 2006. p.273-83.

RODOTÀ, S. La legge i dilemmi dela libertà. In: BORASCHI, A.; MANCONI, L. (Coords.). Il dolore e la politica: accanimento terapeutico, testamento biologico, libertà di cura. Milano: Mondadori Bruno, 2007.

RODRIGUES, J. V. O consentimento informado para o acto médico no ordenamento jurídico português (elementos para o estado da manifestação da vontade do paciente). Coimbra: Coimbra, 2001.

RODRIGUES, R. de L. Diretivas antecipadas: planejamento preventivo para decisões futuras sobre o exercício do direito ao corpo, à saúde e à vida digna. In: DADALTO, L.; TEIXEIRA, A. C. B. (Orgs.). Dos hospitais aos tribunais. Belo Horizonte, 2013.

RODRÍGUEZ, V. G. O ensaio como tese: estética e narrativa na composição do texto científico. São Paulo: WMF Martins Fontes, 2012.

ROY, D. J. La biomédecine aujourd'hui et l'homme de demain. Point de départ et direction de la bioéthique. Le Suplement, Paris, n.128, p.5975, mar. 1979.

SÁ, M. de F. F. de. Direito de morrer: eutanásia, suicídio assistido. 2.ed. Belo Horizonte: Del Rey, 2005.

; NAVES, B. T. de O. Manual de biodireito. Belo Horizonte: Del Rey, 2009.

SAMPAIO, A. C.; SILVA, M. R. F. da. Prontuários médicos: reflexo das relações médico-paciente. Revista Bioética, Brasília, DF, v.18, n.2, p.451-68, 2010.

SANTOS, M. C. C. L. dos. O equilíbrio do pêndulo. São Paulo: Ícone, 1998. SÃO PAULO. Lei n. 10.241, de 17 de março de 1999. Dispõe sobre os direitos dos usuários dos serviços e das ações de saúde no estado e dá 
outras providências. Diário Oficial do Estado, São Paulo, 18 mar. 1999. p.32. Disponível em: <http://www.pge.sp.gov.br/centrodeestudos/ bibliotecavirtual/dh/volume\%20i/saudelei10241.htm>. Acesso em: 13 abr. 2013.

SARLET, I. W. Dignidade da pessoa humana e direitos fundamentais na Constituição Federal de 1988. 5.ed. Porto Alegre: Livraria do Advogado, 2007.

A eficácia dos direitos fundamentais. Porto Alegre: Livraria do Advogado, 1998.

SARMENTO, D. A ponderação de interesses na Constituição Federal. Rio de Janeiro: Lumen Juris, 2002.

SARTRE, J.-P. O ser e o nada: ensaio de ontologia fenomenológica. 16.ed. Rio de Janeiro: Vozes, 2008.

SAUWEN, R. F.; HRYNIEXICZ, S. O direito "in vitro": da bioética ao biodireito. Rio de Janeiro: Lumen Juris, 1997.

SCHOTSMANS, P. T. O homem como criador? Desenvolvimentos na genética humana e os limites da autodeterminação humana. Cadernos Adenauer, Rio de Janeiro, n.1, p.11-33, 2002.

SCHRAMM, F. R. O uso problemático do conceito "vida" em bioética e suas interfaces com a práxis biopolítica e os dispositivos de biopoder. Revista Bioética, Brasília, DF, v.17, n.3, p.377-89, 2009.

A moralidade da biotecnociência: a bioética da proteção pode dar conta do impacto real e potencial das biotecnologias sobre a vida e/ou a qualidade de vida das pessoas humanas? In: et al. (Orgs.). Bioética: riscos e proteção. Rio de Janeiro: Ed. UFRJ/Fiocruz, 2005.

SCOFANO, M. C. C. Biodireito, um novo desafio. Janus, Lorena, v.3, n.4, p.95-111, jul.-dez. 2006. Disponível em: <http://publicacoes. fatea.br/index.php/janus/article/viewFile/39/42>. Acesso em: 3 fev. 2014.

SCRIGNI, A. Bioética e problemas de final de vida - uma experiência de limitação de suporte vital em um hospital de alta complexidade. Tradução de Maria Stela Gonçalves, Adail Sobral e Luis Fernando Spósito. In: PESSINI, L.; BARCHIFONTAINE, C. de P. de (Orgs.). Bioética clínica e pluralismo. São Paulo: Ed. Centro Universitário São Camilo/Loyola, 2013.

SEGRE, M. Definição de bioética e sua relação com a ética, deontologia e diceologia. In: SEGRE, M.; COHEN, C. (Orgs.). Bioética. São Paulo: Edusp, 2002. 
SERRÃO, D. Ética das atitudes médicas em relação com o processo de morrer. In: SERRÃO, D.; NUNES, R. (Coords.). Ética em cuidados de saúde. Porto: Porto, 1998.

SGRECCIA, E. Manual de bioética: fundamentos e ética biomédica. Tradução de Orlando Soares Moreira. 3.ed. rev. e ampl. São Paulo: Loyola, 2009.

SILVA, De P. e. Vocabulário jurídico. Rio de Janeiro: Forense, 1991. Vocabulário jurídico. Atualizado por Nagib Slaibi Filho e Gláucia Carvalho. 25.ed. Rio de Janeiro: Companhia Editora Forense, 2004.

SILVA, J. A. da. Curso de direito constitucional positivo. 22.ed. São Paulo: Malheiros, 2003.

SILVA, V. A. da. Direitos fundamentais: conteúdo essencial, restrições e eficácia. São Paulo: Malheiros, 2009.

SIQUEIRA-BATISTA, R.; SCHRAMM, F. R. Conversações sobre a "boa morte": o debate bioético acerca da eutanásia. Cadernos de Saúde Pública, Rio de Janeiro, v.21, n.1, p.113-20, jan.-fev. 2005.

SOARES, R. M. F. Direito, justiça e princípios constitucionais. Salvador: Juspodivm, 2008.

SOCIEDADE BRASILEIRA DE BIOÉTICA. Lei da "morte digna" é aprovada no Senado Argentino, Brasília, DF, 14 maio 2012. Disponível em: <http://www.sbbioetica.org.br/noticia/lei-da-morte-digna-e-aprovada-no-senado-argentino/>. Acesso em: 28 jun. 2014.

SOUSA, P. H. M. de. De Kevorkian a Egoyan: o suicídio assistido entre o direito e a arte. In: DADALTO, L. (Coord.). Diretivas antecipadas de vontade: ensaios sobre o direito à autodeterminação. Belo Horizonte: Letramento, 2013.

SOUSA, R. V. A. C. de. O direito geral de personalidade. Coimbra: Coimbra, 1995.

SOUZA, C. H. B. de. Eutanásia, distanásia e suicídio assistido. In: SÁ, M. de F. F. de (Org.). Biodireito. Belo Horizonte: Del Rey, 2002.

STOCO, R. Tratado de responsabilidade civil. 6.ed. rev., atual. e ampl. São Paulo: Ed. Revista dos Tribunais, 2004.

STRENGER, I. História da filosofia. São Paulo: LTr, 1998.

SZTAJN, R. Reflexões sobre o consentimento informado. In: AZEVEDO, A. V.; LIGIERA, W. R. (Coords.). Direitos do paciente. São Paulo: Saraiva, 2012.

TAMAYO, C. T.; LEE, G. M.; MATA, O. C. M. (Eds.). Consentimiento válidamente informado. México: Conamed, 2004. 
TARTUCE, F. Os direitos da personalidade no novo Código Civil. Jus Navigandi, Teresina, ano 10, n.878, 28 nov. 2005. Disponível em: $<$ http://jus.com.br/artigos/7590>. Acesso em: 10 jun. 2014.

TAVARES, F. de M. Reflexões acerca da iatrogenia e educação médica. Revista Brasileira de Educação Médica, Rio de Janeiro, v.31, n.2, p.180-5, 2007.

TAVARES, M. de S. Aspectos éticos da quebra da relação médicopaciente. Revista Bioética, Brasília, DF, v.16, n.1, p.125-31, 2008.

TEIXEIRA, A. C. B. Saúde, corpo e autonomia privada. Rio de Janeiro: Renovar, 2010.

TEPEDINO, G. Crise de fontes normativas e técnica legislativa na parte geral do Código Civil de 2002. In: (Coord.). A parte geral do novo código civil: estudos na perspectiva civil constitucional. Rio de Janeiro: Renovar, 2002.

; SCHREIBER, A. O extremo da vida - Eutanásia, accanimento terapêutico e dignidade humana. Revista Trimestral de Direito Civil, Rio de Janeiro, v.39, p.3-17, jul.-set. 2009.

THOMAZ, A. C. M. Considerações acerca da obrigatoriedade da aposição do visto de advogado em atos constitutivos de sociedades empresariais. Revista da Emerj, Rio de Janeiro, v.11, n.44, p.147-53, 2008.

TOBEÑAS, J. C. Los derechos de la personalidad. Madri: Instituto Editorial Reus, 1952.

TORREÃO, L. Aspectos éticos na abordagem do paciente terminal em unidade de terapia intensiva pediátrica. São Paulo, 2001. Dissertação (Mestrado em Ciências Médicas) - Faculdade de Medicina, Universidade de São Paulo.

UNESCO. Towards Declaration on Universal Norms on Bioethics: progress report january 2005. Paris, 2005. Disponível em: <http://www. unesco.org/new/fileadmin/MULTIMEDIA/HQ/SHS/pdf/bioethics_declaration_jan2005.pdf $>$. Acesso em: 3 maio 2014.

- Declaração Universal sobre Bioética e Direitos Humanos. Lisboa, 2006. Disponível em: <http://unesdoc.unesco.org/ images/0014/001461/146180por.pdf>. Acesso em: 3 maio 2014.

URUGUAI. Ley n. 18.473, de 3 de abril de 2009. Voluntad antecipada. Se incorpora a nuestro ordenamiento jurídico y se establece su alcance. Diário Oficial, Poder Legislativo, Montevideo, 21 abr. 2009, n.27.714. Disponível em: <http://200.40.229.134/leyes/AccesoTextoLey. asp? Ley=18473\&Anchor=>. Acesso em: 28 jun. 2014. 
VADELL, L. M. B. La garantia de la Assistência de Letrado: función social y relevancia constitucional. In: PAIVA, M. A. L. de (Org.). A importância do advogado para o direito, a justiça e a sociedade. Mário Antônio Lobato de Paiva. Rio de Janeiro: Forense, 2000.

VASCONCELOS, P. P. Direito de personalidade. Coimbra: Almedina, 2006.

VAZ, J. M. Questões actuais de ética médica. 3.ed. Braga: A.O., 1990.

VILLAS-BÔAS, M. E. A ortotanásia e o direito penal brasileiro. Revista Bioética, Brasília, DF, v.16, n.1, p.61-83, 2008.

ZANCHETTA, R. Il testamento biológico: note a margine del ddl. Calabrò: Exeo, 2012.

ZIMERMAN, D. A dignidade diante da morte, sob a ótica de um psicanalista. In: BARBOZA, H. H.; MENEZES, R. A.; PEREIRA, T. da S. (Coords.). Vida, morte e dignidade humana. Rio de Janeiro: GZ, 2010.

ZOBOLI, E. Tomada de decisão em bioética clínica: casuística e deliberação moral. Revista Bioética, Brasília, DF, v.21, n.3, p.389-96, 2013. 


\section{SOBRE OS AUTORES}

Matheus Massaro Mabtum. Graduado em Direito pela Faculdade de Direito de Franca. Mestre em Direito pela Universidade Estadual Paulista "Júlio de Mesquita Filho" (Unesp). Especialista em Direito Administrativo. Professor no Centro Universitário Unifafibe. Professor substituto na Universidade Estadual Paulista "Júlio de Mesquita Filho". Advogado inscrito nos quadros da Ordem dos Advogados do Brasil, secção de São Paulo. Membro titular do comitê de ética em pesquisas com seres humanos da Faculdade de Ciências Farmacêuticas de Ribeirão Preto (FCFRP - USP) para o período 20142016. Membro grupo de pesquisa Observatório de Bioética e Direito, da Universidade Estadual Paulista "Júlio de Mesquita Filho".

Patrícia Borba Marchetto. Doutora em Direito pela Universidad de Barcelona (2001), com título reconhecido pela Faculdade de Direito da Universidade de São Paulo. Professora na graduação e na pós-graduação na Universidade Estadual Paulista Júlio de Mesquita Filho. Tem experiência na área de Direito, com ênfase em Bioética, Direito Tributário e Administrativo, atuando principalmente nos seguintes temas: responsabilidade social empresarial e bioética. Membro do Centro de Estudos e Práticas Pedagógicas da Unesp (Cenepp-Unesp). Desenvolve vários projetos de extensão e é tutora de grupo de Educação Tutorial (PET-Administração Pública/Unesp), vinculado ao MEC-Sesu. 
SOBRE O LIVRO

Formato: $14 \times 21 \mathrm{~cm}$

Mancha: 23,7 x 42,5 paicas

Tipologia: Horley Old Style 10,5/14

EQUIPE DE REALIZAÇÃO

Coordenação Geral

Maria Luiza Favret 


\section{CULTURA}

$\frac{\text { ACADÊMICA }}{\varepsilon d i t o n a}$ 